\author{
Mon ograph \\ urn:1sid:zoobank.org:pub:519E2F56-40E1-4431-BC90-8484E308D16E
}

\title{
Revision of the cricket genus Nisitrus Saussure (Orthoptera: Gryllidae: Eneopterinae) and descriptions of five new species
}

\author{
Ming Kai TAN ${ }^{1, *}$, Rodzay bin Haji Abdul WAHAB ${ }^{2}$, Razy JAPIR ${ }^{3}$, \\ Authur Y.C. CHUNG ${ }^{4} \&$ Tony ROBILLARD ${ }^{5, *}$ \\ 1,5 Institut de Systématique, Evolution et Biodiversité (ISYEB), Muséum national d'histoire naturelle, \\ CNRS, SU, EPHE, UA, 57 rue Cuvier, CP 50, 75231 Paris Cedex 05, France. \\ ${ }^{2}$ Institute for Biodiversity and Environmental Research, Universiti Brunei Darussalam, \\ Jalan Universiti, BE1410, Brunei Darussalam. \\ ${ }^{3,4}$ Forest Research Centre (Sepilok), Sabah Forestry Department, P.O. Box 1407, \\ 90715 Sandakan, Sabah, Malaysia.
}

*Corresponding authors: orthoptera.mingkai@gmail.com (MKT); tony.robillard@mnhn.fr (TR)

${ }^{2}$ Email: rodzay.wahab@ubd.edu.bn

${ }^{3}$ Email: razy.Japir@sabah.gov.my

${ }^{4}$ Email: arthur.Chung@sabah.gov.my

${ }^{1}$ urn:lsid:zoobank.org:author:2F544BE6-7986-4905-AE51-CF16B44D5251

${ }^{2}$ urn:1sid:zoobank.org:author:50868E6A-34E4-471A-B941-C504CC9E895A

${ }^{3}$ urn:Isid:zoobank.org:author:B05E507D-FBA4-437F-AB03-94E349912EA5

${ }^{4}$ urn:lsid:zoobank.org:author:6E7371D6-6FF9-42DF-8745-4A8304CB0978

${ }^{5}$ urn:1sid:zoobank.org:author:19BBE007-85D2-4325-8396-A1F4BAF5775C

\begin{abstract}
Nisitrus Saussure, 1878 is a diurnal and monophyletic group of eneopterine crickets found in parts of Southeast Asia. Species often have vivid colourations which make them charismatic photograph subjects among macro photographers. However, their taxonomy has not been revised since their original descriptions, whereas there are also species awaiting to be discovered and described. A synoptic revision is therefore needed prior to studying the phylogenetic relationships of the genus, and before undertaking more precise studies on biogeography and evolution of traits. By holistically incorporating information about general morphology, male and female genitalia, and bioacoustics, we revise the taxonomy of these crickets and recognise 10 valid species of Nisitrus. Five new species are described: $N$. crucius Robillard \& Tan sp. nov. from Borneo; $N$. danum Robillard \& Tan sp. nov. from Borneo; N. hughtani Robillard \& Tan sp. nov. from Sumatra; N. malaya Robillard \& Tan sp. nov. from Malay Peninsula; and N. rindu Robillard \& Tan sp. nov. from Borneo. We redescribe N. brunnerianus and N. insignis; describe the calls of $N$. malaya sp. nov., $N$. musicus and $N$. vittatus. We consider $N$. sumatrensis as a junior synonym of $N$. insignis; and $N$. marginata as a junior synonym of $N$. vittatus. Nisitrus hyalinus requires further revision. We also consider $N$. maculosus as a dubious name.
\end{abstract}

Keywords. Nisitrini, key, lectotype, redescription, Southeast Asia. 
Tan M.K., Wahab R.H.A., Japir R., Chung A.Y.C. \& Robillard T. 2021. Revision of the cricket genus Nisitrus Saussure (Orthoptera: Gryllidae: Eneopterinae) and descriptions of five new species. European Journal of Taxonomy 761: 1-75. https://doi.org/10.5852/ejt.2021.761.1449

\section{Introduction}

Nisitrus Saussure, 1878 is a monophyletic and morphologically unique group of common eneopterine crickets distributed in Southeast Asia (Fig. 1). It belongs to the tribe Nisitrini Robillard, 2004 along with the apterous genus Paranisitra Chopard, 1925, which was taxonomically reviewed in a recent study (Baroga-Barbecho et al. 2019). Unlike many eneopterines, Nisitrus are slender with long legs, with contrasting vivid colourations (generally black and yellow), with transparent forewings in males, and fully developed hindwings (often with colour patterns) capable of short distance flight. Currently, eight species are known from Borneo, Malay Peninsula and Sumatra, but extinct populations are reported from Java and, probably erroneously, from Maluka (Cigliano et al. 2020).

Nisitrus are diurnal, and males can be heard calling among vegetation throughout daytime (Fig. 2). As these crickets usually stay on the foliage, they tend to feed on fresh leaves and flowers (Tan et al. 2017). They can be widely distributed and abundant locally (e.g., Tan et al. 2012, 2013a, 2015; Tan \& Wahab
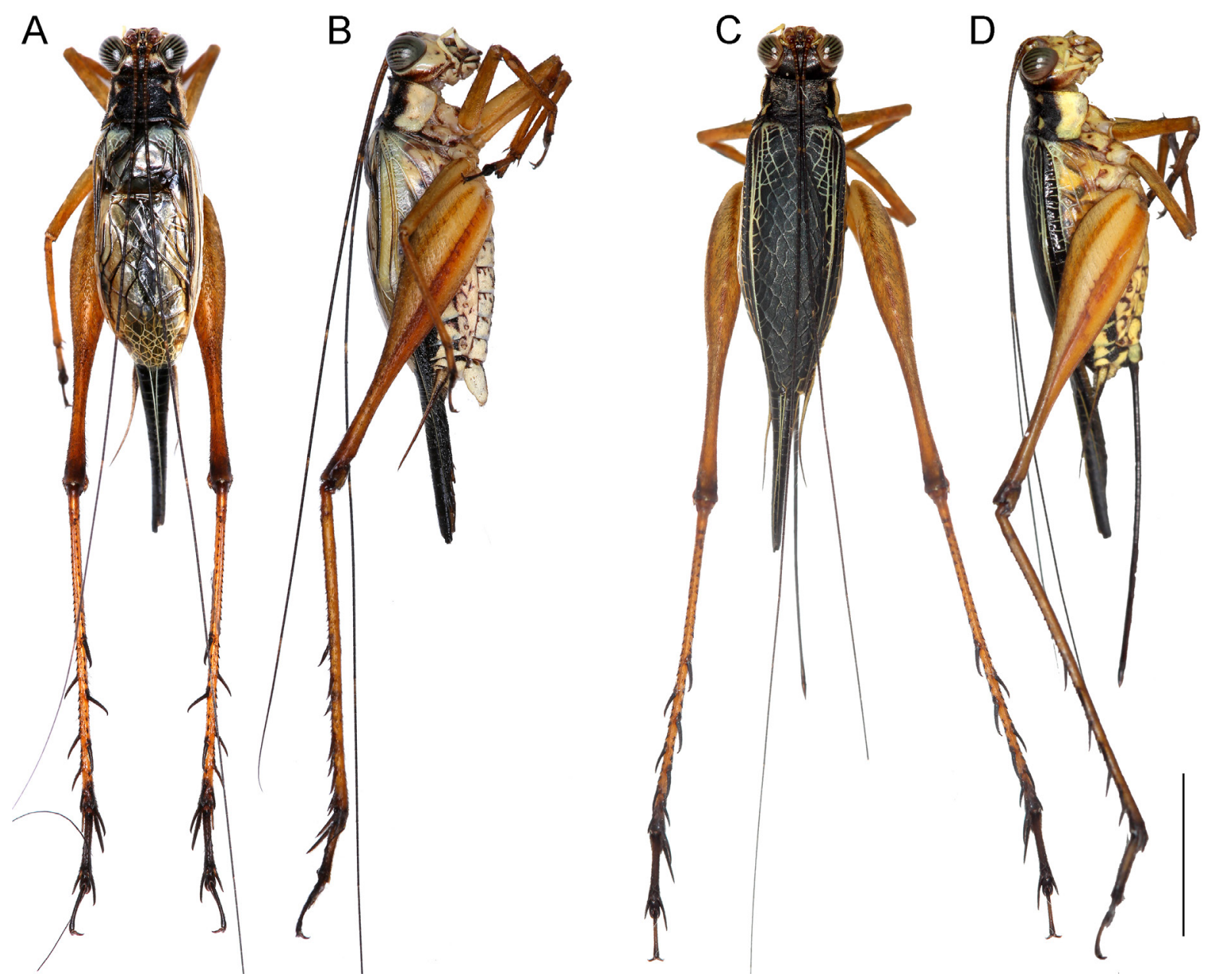

Fig. 1. Habitus of Nisitrus vittatus (Haan, 1844) in dorsal (A, C) and lateral (B, D) views. A-B. §̊. C-D. 오. Scale bar $=5 \mathrm{~mm}$. 

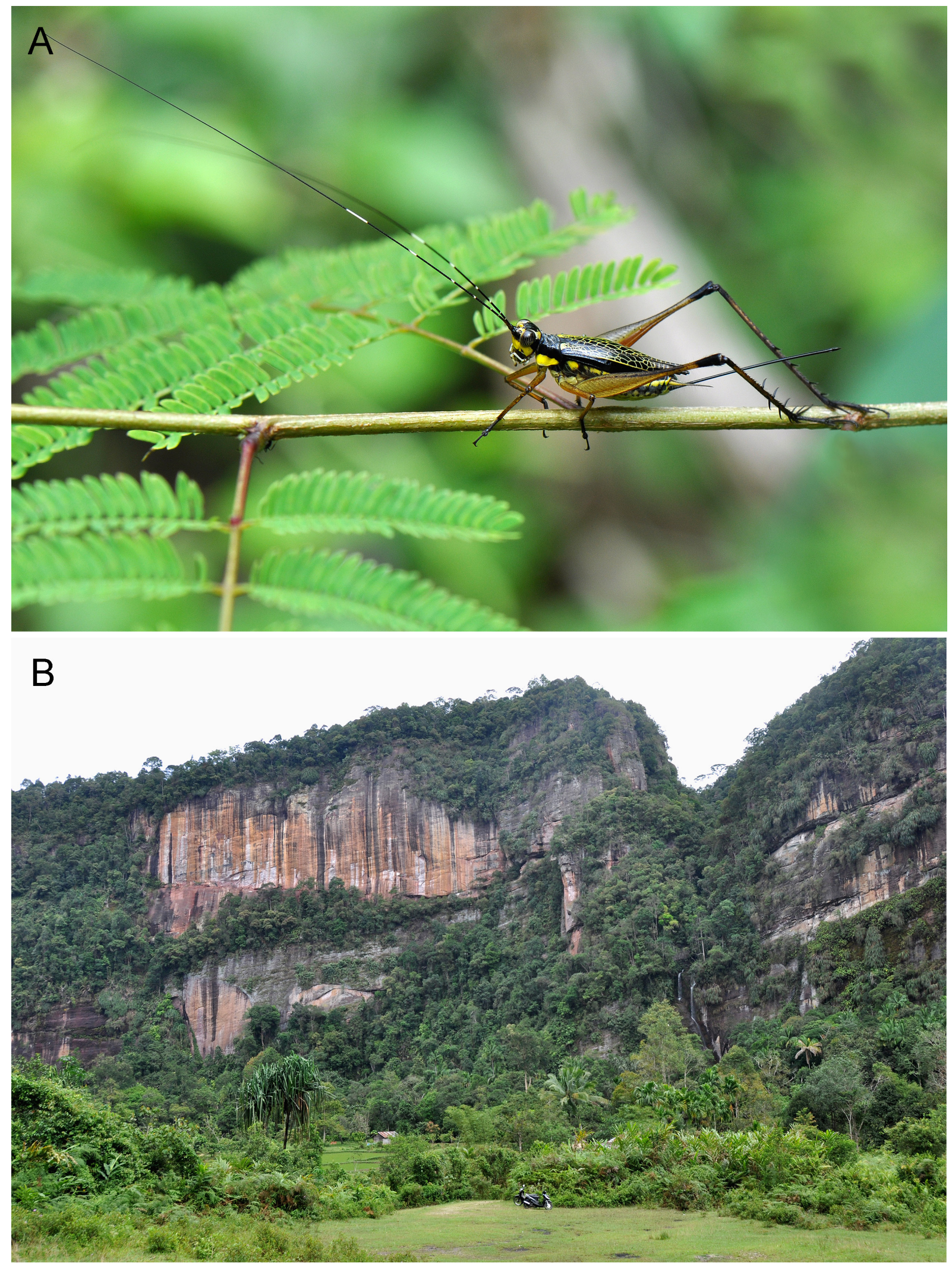

Fig. 2. A. Nisitrus insignis Saussure, 1878, adult ${ }$. B. Natural habitat of a typical Nisitrus Saussure, 1878, Lima Puluh Koto, Sumatra, Indonesia. Photograph source and credits: iNaturalist; Dries Nys and Marion Vancauwenbergh. 
2018). As such, they can easily be spotted by macro photographers (thanks to their flamboyant nature, bright colouration and diurnal nature) and they make charismatic photograph subjects and are also often observed by citizen science initiative participants such as iNaturalist, where they add up to at least 700 observations from 265 observers (iNaturalist 2020).

In the context of the study of the evolution of communication systems in crickets, the genus is also often used as a representative member of the eneopterine clades that produce low-frequency acoustic signals, by comparison to species producing high frequencies (Robillard et al. 2013; ter Hofstede et al. 2015; Schneider et al. 2017). As such, and due to the facility to breed them in captivity, they are also excellent candidates for detailed studies on the acoustic communication in crickets, even if these studies focus mainly on a single species only.

Such studies are also possible because Nisitrus has been recognised as a stable monophyletic group (see Robillard \& Desutter-Grandcolas 2006; Vicente et al. 2017), having been established to be sister to the clade containing both tribes Xenogryllini Robillard, 2004 and Lebinthini Robillard, 2004 (Vicente et al. 2017). While the monophyly of the genus is well supported, the relationships among species of Nisitrus are still unclear, since hitherto four species were represented in the phylogenies. More crucially, this is also attributed to the absence of a systematic revision and species clarification for the genus, and to the fact that several species are potentially awaiting discovery.

The taxonomy of these crickets remains problematic, with species delimitation and identification difficult among many species. In this study, we revise their taxonomy using an integrative approach. By amassing a large collection of ca 450 specimens from numerous natural history collections around the world and citizen science observations and photographs, we examine and evaluate characters of both male and female genitalia, general morphology and colour patterns of both adults and juveniles. We also used acoustics of the crickets to help infer species boundaries and we present a map of the distribution of each species and a key to species.

\section{Material and methods}

\section{Material}

Specimens in MNHN were studied and additional specimens were loaned from AMNH, AMS, BPBM, FRC, GNME, MHN, MNHN, MZB, NHMUK, NMW, RBINS, RMNH, UBDM, ZIN, ZMH, ZMLU and ZRC (see abbreviations below). Finally, part of the specimens studied here correspond to observation data, mostly from iNaturalist website.

Surveys were also conducted by TR in the lowland forests of Singapore in 2009 and 2011. Surveys were conducted by MKT between 2011 and 2019 in the lowland forests of (1) Singapore, (2) Andulau Forest Reserve, Belait and Kuala Belalong, Temburong of Brunei Darussalam; and (3) Sepilok, Sandakan, Sabah, East Malaysia. Opportunistic collection was conducted during daytime. Whenever possible, in-situ images were taken using a Canon EOS 500D digital SLR camera with a compact-macro lens EF $100 \mathrm{~mm} \mathrm{f/2.8}$ Macro USM and Canon Macro Twin Lite MT-24EX was used for lighting and flash. The specimens were preserved in absolute analytical-grade ethanol and later pinned and dry-preserved. A single hind leg from each specimen was also preserved in absolute analytic-grade ethanol for future molecular work. Newly collected specimens are deposited in the collections of the FRC, MNHN, UBDM and ZRC.

\section{Morphology}

Male tegminal veins and cells follow terminology by Desutter-Grandcolas (2003) and Robillard \& Desutter-Grandcolas (2004a) (Fig. 3). Male and female genitalia have been dissected in softened specimens by cutting the membranes between the paraprocts and the subgenital plate, or between the 
ovipositor and the subgenital plate respectively; they have been observed after cleaning with cold $\mathrm{KOH}$, and then kept in glycerine. Male genitalia are named according to Desutter (1987), modified in DesutterGrandcolas (2003) and Robillard \& Desutter-Grandcolas (2004a) (Fig. 4). We also provide terminology used by Gorochov (2015) in square brackets. Female genitalia are named according to Robillard \& Tan (2013). Abbreviations: see below.

\section{Molecular data}

We used a fragment of the mitochondrial gene $12 \mathrm{~S}$ rRNA gene (12S, amplicon $\sim 400 \mathrm{bp}$ ) as a barcoding marker. DNA extraction, PCR amplification, and sequencing for all newly generated sequences were carried out at Service de Systématique moléculaire of the MNHN, following the protocols as described in Dong et al. (2018), including primers and annealing temperatures.

Sequences were cleaned and checked for sequencing errors in Sequencher ver. 4.9 (Gene Codes Co.) or Geneious ver. R9.0.2 (Biomatter Ltd., New Zealand, www.geneious.com; Kearse et al. 2012), and BioEdit ver. 7.0.5.3 (Hall 1999), then blasted with NCBI blast tools, and submitted to GenBank (Table 1).

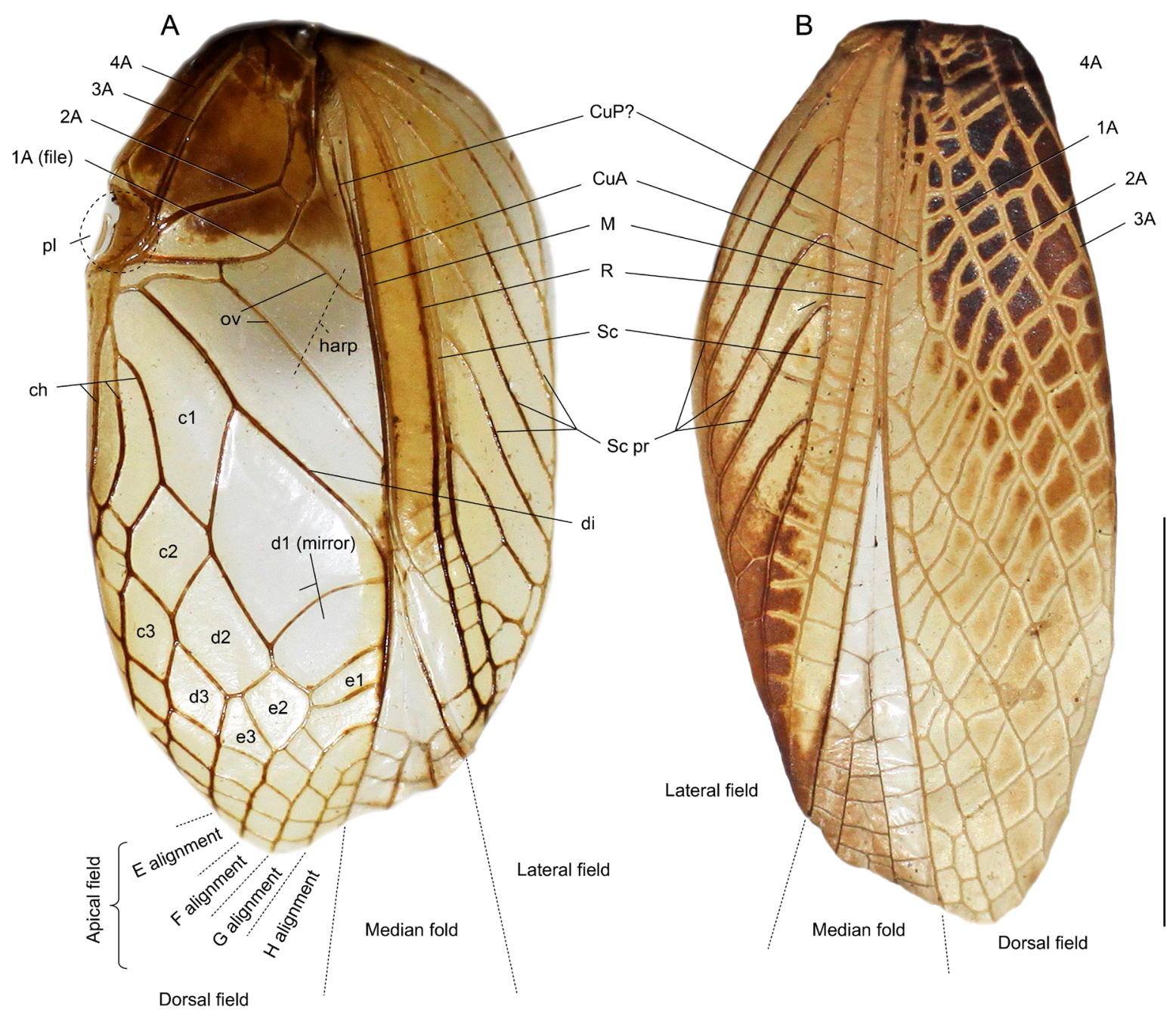

Fig. 3. Forewing venations (with labels of the veins and areas) of Nisitrus vittatus (Haan, 1844). A. $\widehat{O}^{\text {. }}$. B. . . Scale bar $=5 \mathrm{~mm}$. 
The sequences were aligned with MAFFT ver. 7 online (Kuraku et al. 2013; Katoh et al. 2017). The complete combined dataset consisted of 403 aligned base pairs (bp) for a total of 28 terminals, including 3 sequences of the species Paranisitra longipes Chopard, 1925 to represent the sister genus Paranisitra, and 1 sequence of Gryllus bimaculatus De Geer, 1773, used as outgroup in the phylogenetic analysis. Phylogenetic analyses were carried out using the IQ-TREE web server (http://iqtree.cibiv.univie.ac.at/; Trifinopoulos et al. 2016); maximum likelihood phylogenetic reconstruction was run using IQ-TREE ver. 1.6. 2 web portal (Nguyen et al. 2015) (http://iqtree.cibiv.univie.ac.at/) and ModelFinder (Kalyaanamoorthy 2017). Clade support was assessed by conducting 1000 ultrafast bootstrap replicates (Hoang et al. 2017). Branches supported by bootstrap support values (BS) $\geq 70 \%$ were considered strongly supported.

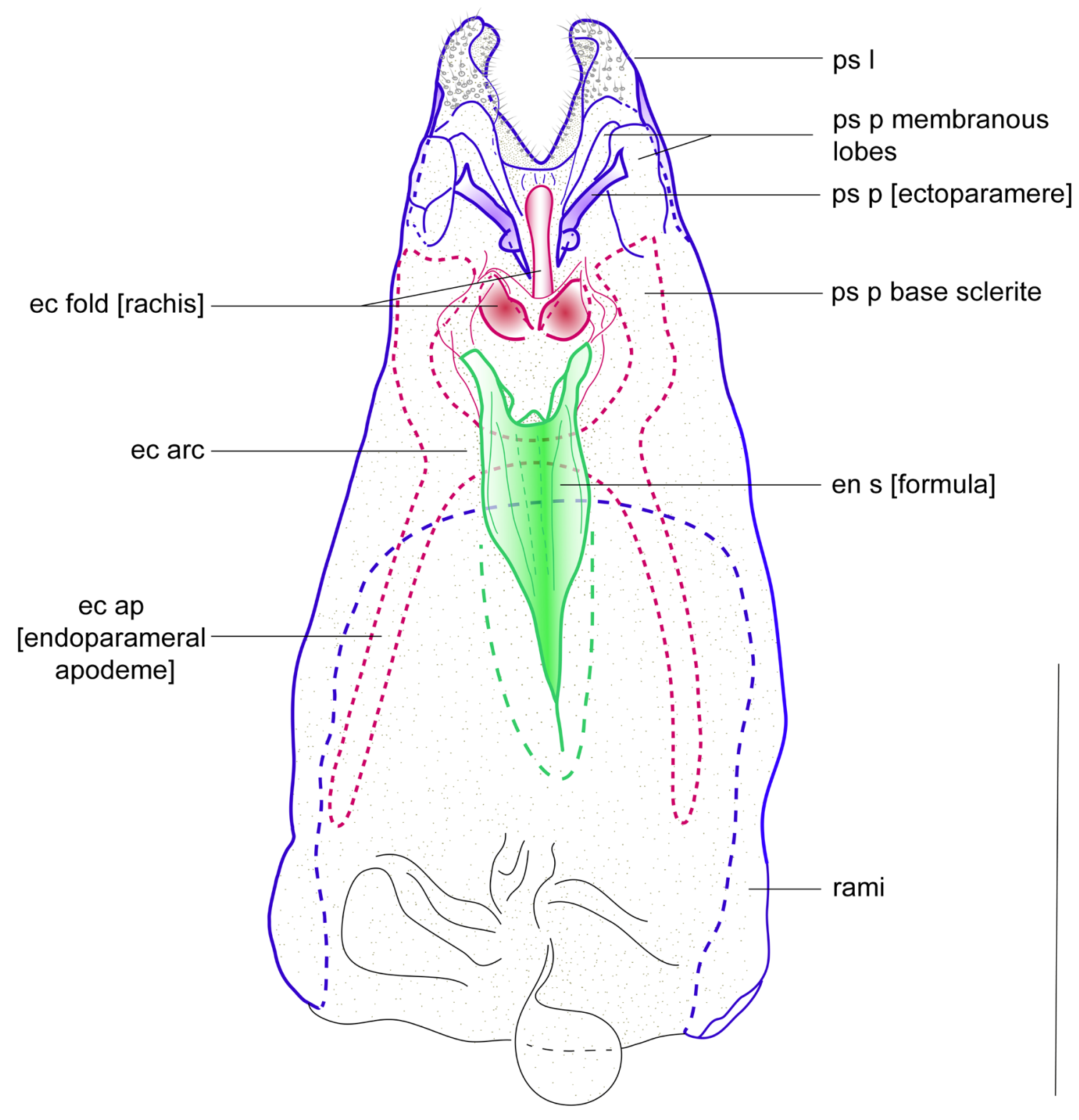

Fig. 4. Drawing of male genitalia of N. malaya Robillard \& Tan sp. nov. (with labels of parts). Abbreviations: see Material and methods; names of structures follow Desutter (1987), modified after Desutter-Grandcolas (2003) and Robillard \& Desutter-Grandcolas (2004a). Terminology used by Gorochov (2015) in square brackets. Scale bar $=1 \mathrm{~mm}$. 
TAN M.K. et al., Revision of Nisitrus (Orthoptera: Eneopterinae)

Table 1. List of specimens and their details used to construct the 12S gene tree.

\begin{tabular}{|c|c|c|c|c|}
\hline Species & Collection/Voucher & Lab code & Origin & $\begin{array}{l}\text { Genbank } \\
\text { accession }\end{array}$ \\
\hline Nisitrus brunnerianus & ZRC & N2Nka1 & Indonesia: Kalimantan & KY595480 \\
\hline $\begin{array}{l}\text { Nisitrus hughtani } \\
\text { sp. nov. }\end{array}$ & ZIN & N34Nnb1 & Indonesia: West Sumatra & MW264327 \\
\hline Nisitrus insignis & MNHN-EO-ENSIF4180 & N5Nin & Indonesia: West Sumatra & KY595491 \\
\hline Nisitrus insignis & ZIN & $\mathrm{N} 35 \mathrm{Nin} 2$ & Indonesia: West Sumatra & MW264328 \\
\hline $\begin{array}{l}\text { Nisitrus malaya } \\
\text { sp. nov. }\end{array}$ & MNHN-EO-ENSIF3134 & Nvith & Malaysia: Selangor & AY905284 \\
\hline $\begin{array}{l}\text { Nisitrus malaya } \\
\text { sp. nov. }\end{array}$ & MNHN-EO-ENSIF2742 & N3NviS & Singapore & MW264323 \\
\hline $\begin{array}{l}\text { Nisitrus malaya } \\
\text { sp. nov. }\end{array}$ & ZRC (UG.17.28) & $\mathrm{N} 47 \mathrm{Nvi}$ & $\begin{array}{l}\text { Malaysia: Ulu Gombak, } \\
\text { Peninsular Malaysia }\end{array}$ & MW264322 \\
\hline Nisitrus musicus & ZIN & N29NboG2 & Malaysia: Borneo, Sabah & MW264324 \\
\hline Nisitrus musicus & MNHN-EO-ENSIF 11070 & $\mathrm{~N} 48 \mathrm{Nmu}$ & Malaysia: Borneo, Sabah & MW264325 \\
\hline Nisitrus vittatus & MNHN-EO-ENSIF1709 & N4NviSA & Malaysia: Borneo, Sabah & MW264317 \\
\hline Nisitrus vittatus & MZB & N6Nka2 & Indonesia: Karimata Is. & MW264321 \\
\hline Nisitrus vittatus & ZIN & N22Ntru2 & Malaysia: Borneo Sabah & MW264307 \\
\hline Nisitrus vittatus & ZIN & N23Nbeng1 & Malaysia: Borneo, Sarawak & MW264308 \\
\hline Nisitrus vittatus & ZIN & N24Nku1 & Malaysia: Borneo, Sabah & MW264309 \\
\hline Nisitrus vittatus & ZIN & N25Nbo1 & Malaysia: Borneo, Sabah & MW264310 \\
\hline Nisitrus vittatus & ZIN & N26Nbo2 & Malaysia: Borneo, Sarawak & MW264311 \\
\hline Nisitrus vittatus & ZIN & N27Nbo3 & Malaysia: Borneo, Sabah & MW264320 \\
\hline Nisitrus vittatus & ZIN & N28Nbo4 & Malaysia: Borneo, Sabah & MW264312 \\
\hline Nisitrus vittatus & ZIN & N30Nku2 & Malaysia: Borneo, Sarawak & MW264313 \\
\hline Nisitrus vittatus & ZIN & N31Nlamp1 & Indonesia: Sumatra, Lampung & MW264318 \\
\hline Nisitrus vittatus & ZIN & N32Nbo5 & Malaysia: Borneo, Sabah & MW264314 \\
\hline Nisitrus vittatus & ZIN & N33Nlamp2 & Indonesia: Sumatra, Lampung & MW264315 \\
\hline Nisitrus vittatus & ZIN & N36Nlamp3 & Indonesia: Sumatra Selatan & MW264319 \\
\hline Nisitrus vittatus & MNHN-EO-ENSIF11069 & N37Nbd1 & $\begin{array}{l}\text { Brunei Darussalam: Kulala } \\
\text { Belalong }\end{array}$ & MW264316 \\
\hline Paranisitra longipes & UPLBMNH & N44Plo & Philippines: Luzon & MW264329 \\
\hline Paranisitra longipes & UPLBMNH & N45Plo & Philippines: Luzon & MW264330 \\
\hline Paranisitra longipes & UPLBMNH & N46Plo & Philippines: Luzon & MW264331 \\
\hline Gryllus bimaculatus & MNHN-EO-ENSIF3524 & Gbi2 & lab-colony & AY905292 \\
\hline
\end{tabular}

\section{Acoustics}

The basic cricket song terminology follows Ragge \& Reynolds (1998). One song unit is called a syllable and corresponds to one opening-closure cycle of the male forewings.

The calls of three species are described (i.e., N. malaya Robillard \& Tan sp. nov. and N. musicus Ingrisch, 1987) and redescribed (i.e., N. vittatus (Haan, 1844)) here having been recorded in the field and/or in the laboratory from specimens collected as juveniles or sub-adults. The recordings were made with a 
modified Condenser Microphone Capsule CM16 (Avisoft Bioacoustics, Berlin), with a flat frequency response from 3 to $150 \mathrm{kHz}$ (R. Specht pers. com.), connected to a Tascam HD-P2 digital recorder ( $96 \mathrm{kHz}$ sampling frequency, 16 bit) in the field, or using Avisoft Triggering Harddisk Recorder ver. 2.97 and an 8-Pre MOTU sound card at a sampling frequency of $96 \mathrm{ksamples} / \mathrm{s}$ (16 bit). Song features were measured using Avisoft Lite ver. 2.0.0. Power spectra using Fast Fourier Transformation (FFT) were generated using the 'meanspec' function at 256000 sampling frequency, using a Hanning window of window length 512 from the R package 'seewave' (Sueur et al. 2008). All recording files are deposited in the Sound Library of the MNHN under accession numbers MNHN-SO-2020-2851 to MNHN-SO-2020-2860.

To examine how the call properties of $N$. malaya sp. nov., $N$. musicus and $N$. vittatus differ, the call properties (which were not mutually independent and likely to be highly intercorrelated) were summarised into major gradients of variation by performing a Principal Coordinates Analysis (PCoA) on the scaled call properties using the 'cmdscale' function in R ver. 3.5.1 (R Development Core Team 2018). The nine call properties are: echeme duration, echeme period, downtime between consecutive echemes, first to third syllable durations, fundamental frequency, frequencies of the second and third harmonics. Gower dissimilarity was used as it can be calculated for a set of descriptors containing continuous values bounded by zero.

\section{Georeferencing of specimen labels}

The description of the localities was manually georeferenced using Google Earth Pro to obtain GPS coordinates. Too imprecise localities were excluded (e.g., only Borneo, Sumatra). Dubious localities were also excluded. For specimens collected during the Midden Oost Borneo Expeditie 1925 in Kalimantan, we georeferenced the localities provided on the map in the book (Buys et al. 1927) (Supp. file 1).

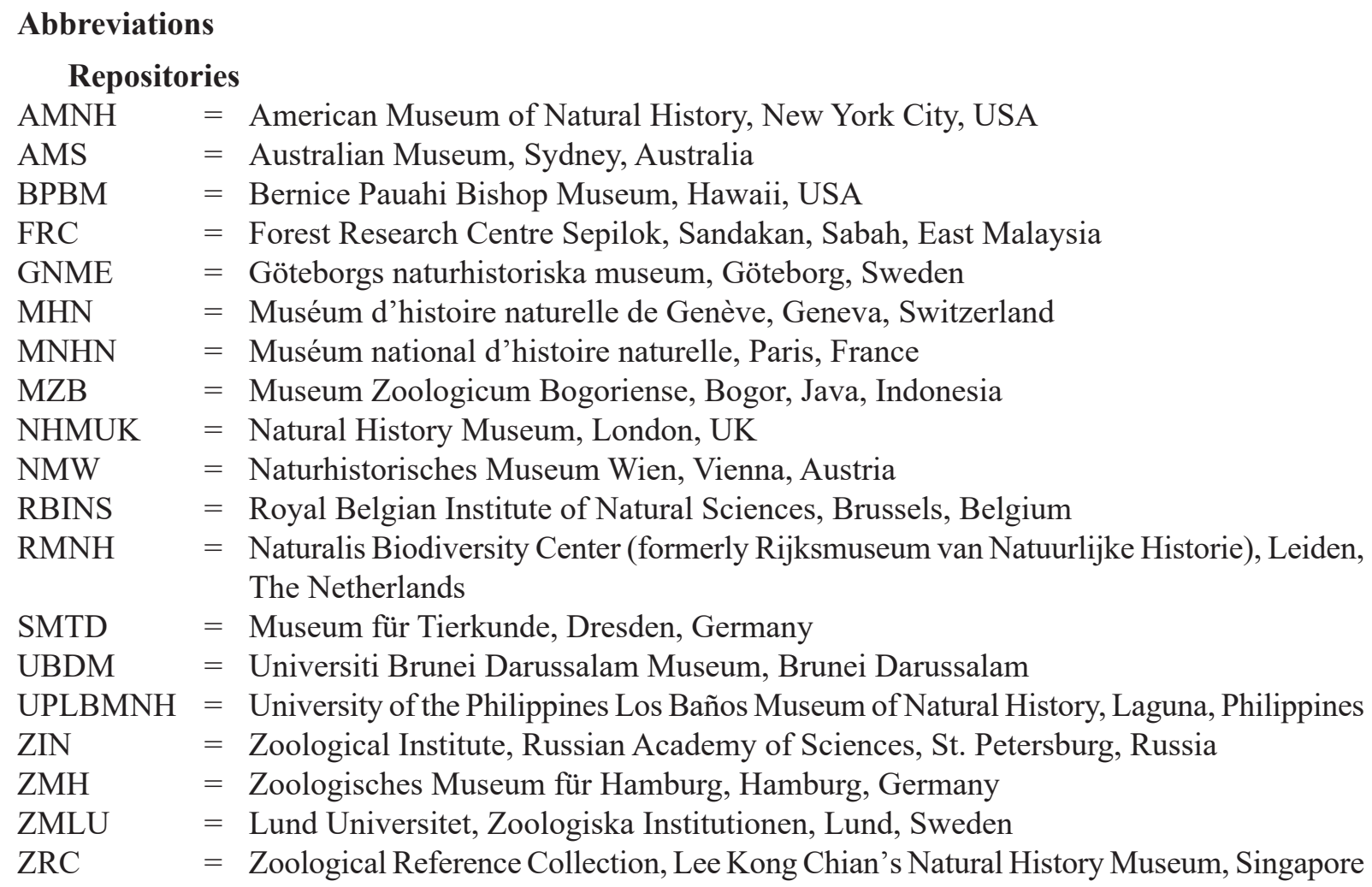

General morphology

I, II, III $\quad$ = front, median, hind respectively (femora, legs, tibiae)

$\mathrm{F} \quad=$ femora 


$$
\begin{aligned}
& \mathrm{FW} \quad=\text { forewing } \\
& \begin{aligned}
\text { Tarsomere III-1 } & =\text { basal segment of hind leg tarsomere } \\
\mathrm{T} & =\text { tibiae } \\
&
\end{aligned} \\
& \text { Tegminal venation (Fig. } 3 \text { ) }
\end{aligned}
$$

$\begin{array}{ll}\text { 1A-4A } & =\text { first to fourth anal veins } \\ \mathrm{c} 1-3 & =\text { first to third cells of } \mathrm{C} \text { alignment } \\ \mathrm{ch} & =\text { chord } \\ \mathrm{CuA} & =\text { anterior cubital vein } \\ \mathrm{CuP} & \text { posterior cubital vein } \\ \mathrm{d} 1 \text { cell (mirror) } & =\text { first cell(s) of } \mathrm{D} \text { alignment } \\ \mathrm{d} 2-3 & =\text { second to third cells of } \mathrm{D} \text { alignment } \\ \mathrm{e} 1-3 & =\text { first to third cells of } \mathrm{E} \text { alignment } \\ \mathrm{ha} & =\text { harp area } \\ \mathrm{M} & =\text { median vein } \\ \mathrm{ov} & =\text { oblique vein } \\ \mathrm{pl} & =\text { plectral area } \\ \mathrm{R} & =\text { radial vein } \\ \mathrm{Sc} & =\text { subcostal vein } \\ \mathrm{Sc} \mathrm{pr} & =\text { subcostal vein projections }\end{array}$

Male genitalia (Fig. 4)

ec arc $=$ ectophallic arc

ec ap = ectophallic apodeme

ec f = ectophallic fold

en ap $=$ endophallic apodeme

en $\mathrm{s}=$ endophallic sclerite

ps $1=$ pseudepiphallic lophi

ps $\mathrm{p}=$ pseudepiphallic paramere

$\mathrm{r} \quad=\mathrm{rami}$

\section{Measurements}

FIIIL $=$ length of hind femora

FIIIW $=$ width of hind femora

$\mathrm{FWL}=$ forewing length

FWW $=$ forewing width (at the level of maximal width)

HWT $=$ hindwing tail

Ias $=$ inner spines on TIII dorsal side, above the spurs

Ibs = inner spines on TIII dorsal side, between the spurs

Oas $=$ outer spines on TIII dorsal side, above the spurs

Obs $=$ outer spines on TIII dorsal side, between the spurs

$\mathrm{OL}=$ ovipositor length

PronL $=$ pronotum length

Pron $\mathrm{W}=$ pronotum width

TIIIL = length of hind tibiae

TaIIIs $=$ spines on outer edge of third hind tarsomere, not including the apical spine 


\section{Results}

Five new species of Nisitrus (Orthoptera Latreille, 1793: Gryllidae Laicharting, 1781: Eneopterinae Saussure, 1874) are described: N. crucius Robillard \& Tan sp. nov. from Borneo; N. danum Robillard \& Tan sp. nov. from Borneo; N. hughtani Robillard \& Tan sp. nov. from Sumatra; N. malaya Robillard \& Tan sp. nov. from Malay Peninsula and N. rindu Robillard \& Tan sp. nov. from Borneo (Table 2). We consider $N$. sumatrensis (Rehn, 1909) as a junior synonym of $N$. insignis Saussure, 1878; and N. marginatus (Walker, 1869) as a junior synonym of $N$. vittatus (Table 1). We also consider N. maculosus (Walker, 1871) as a dubious name (Table 2). In total, we recognise 10 species of Nisitrus: N. brunnerianus Saussure, 1878, N. crucius sp. nov., N. danum sp. nov., N. hughtani sp. nov., N. hyalinus Saussure, 1878, N. insignis, $N$. malaya sp. nov., $N$. musicus, $N$. rindu sp. nov. and N. vittatus (Table 2). The distribution of the nine valid species (excluding $N$. hyalinus) in Southeast Asia is also presented in Fig. 5.

The maximum likelihood tree resulting from the phylogenetic analysis of the mitochondrial gene $12 \mathrm{~S}$ rRNA marker yielded a largely robust topology within the clade of six species of Nisitrus (Fig. 6). Within Nisitrus clade, all species were recovered as monophyletic with high support values, supporting the species delimited by morphology. Nisitrus musicus, $N$. brunnerianus and $N$. hughtani sp. nov. form a well-supported clade (BS of 93.7\%), sister to the clade comprising $N$. vittatus and $N$. malaya sp. nov. (BS of 93.8\%). Specimens of N. vittatus and N. malaya sp. nov. form distinct and well supported clades (BS of $93.4 \%$ and $73.4 \%$, respectively), despite their similarity in adult morphology.

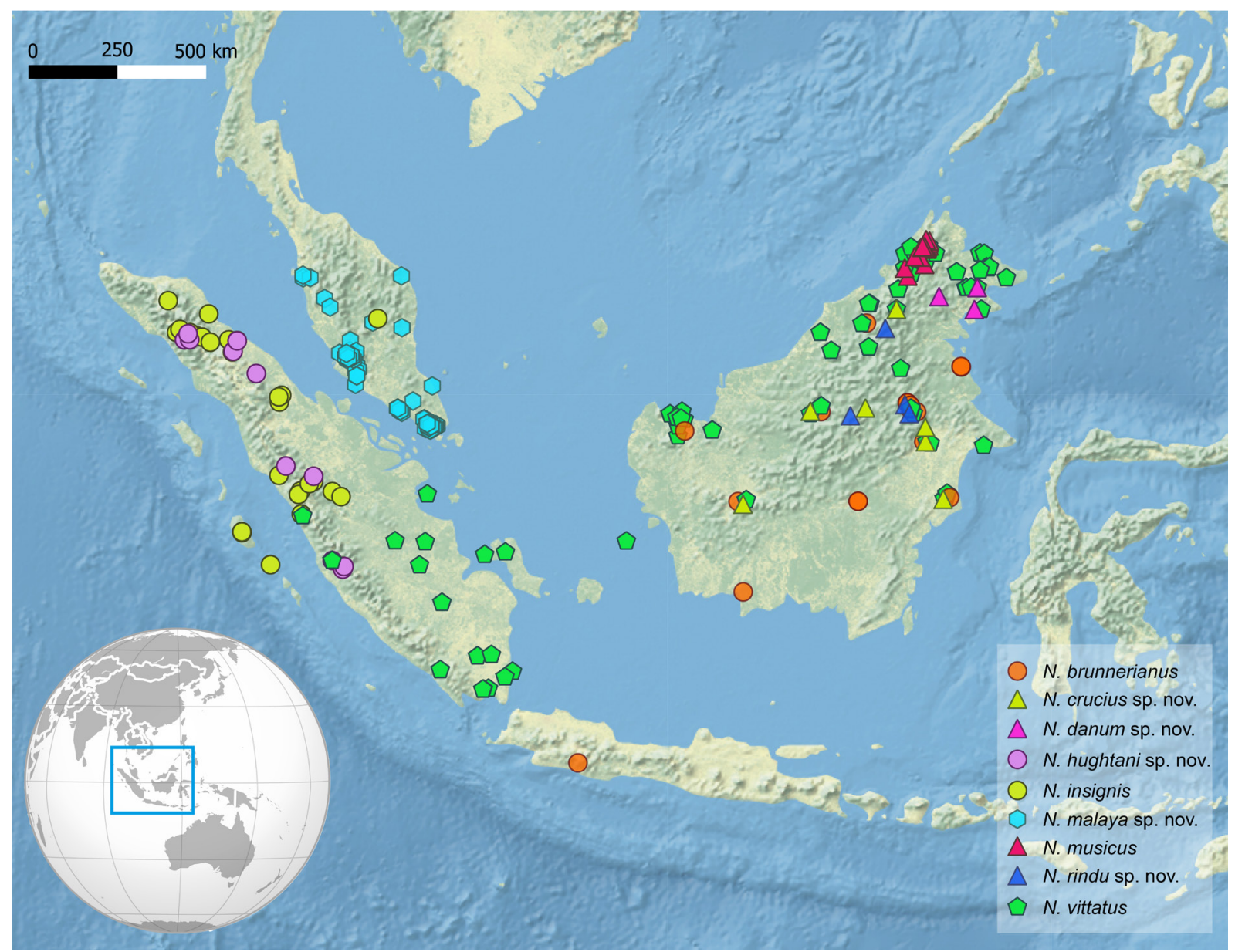

Fig. 5. Map of Southeast Asia showing the distribution of species of Nisitrus Saussure, 1878. Each coloured symbol represents one sampling or observation locality listed in the material in the text. 
Table 2. Status of original species epithets associated with Nisitrus Saussure, 1878.

\begin{tabular}{lll}
\hline Original epithet & Original author and year & Status \\
\hline brunnerianus & Saussure, 1878 & valid (redescribed) \\
crucius & Robillard \& Tan sp. nov. & valid, new species \\
danum & Robillard \& Tan sp. nov. & valid, new species \\
hughtani & Robillard \& Tan sp. nov. & valid, new species \\
hyalinus & Saussure, 1878 & valid, needs further revision \\
insignis & Saussure, 1878 & valid \\
maculosa, maculosus & Walker, 1871 & nomen dubium (new status) \\
malaya & Robillard \& Tan sp. nov. & valid, new species \\
marginata, marginatus & Walker, 1869 & synonym of vittatus (new status) \\
musicus & Ingrisch, 1987 & valid \\
rindu & Robillard \& Tan sp. nov. & valid, new species \\
sumatrensis & Rehn, 1909 & synonym of insignis (new status) \\
vittata, vittatus & Haan, 1844 & valid \\
\hline
\end{tabular}

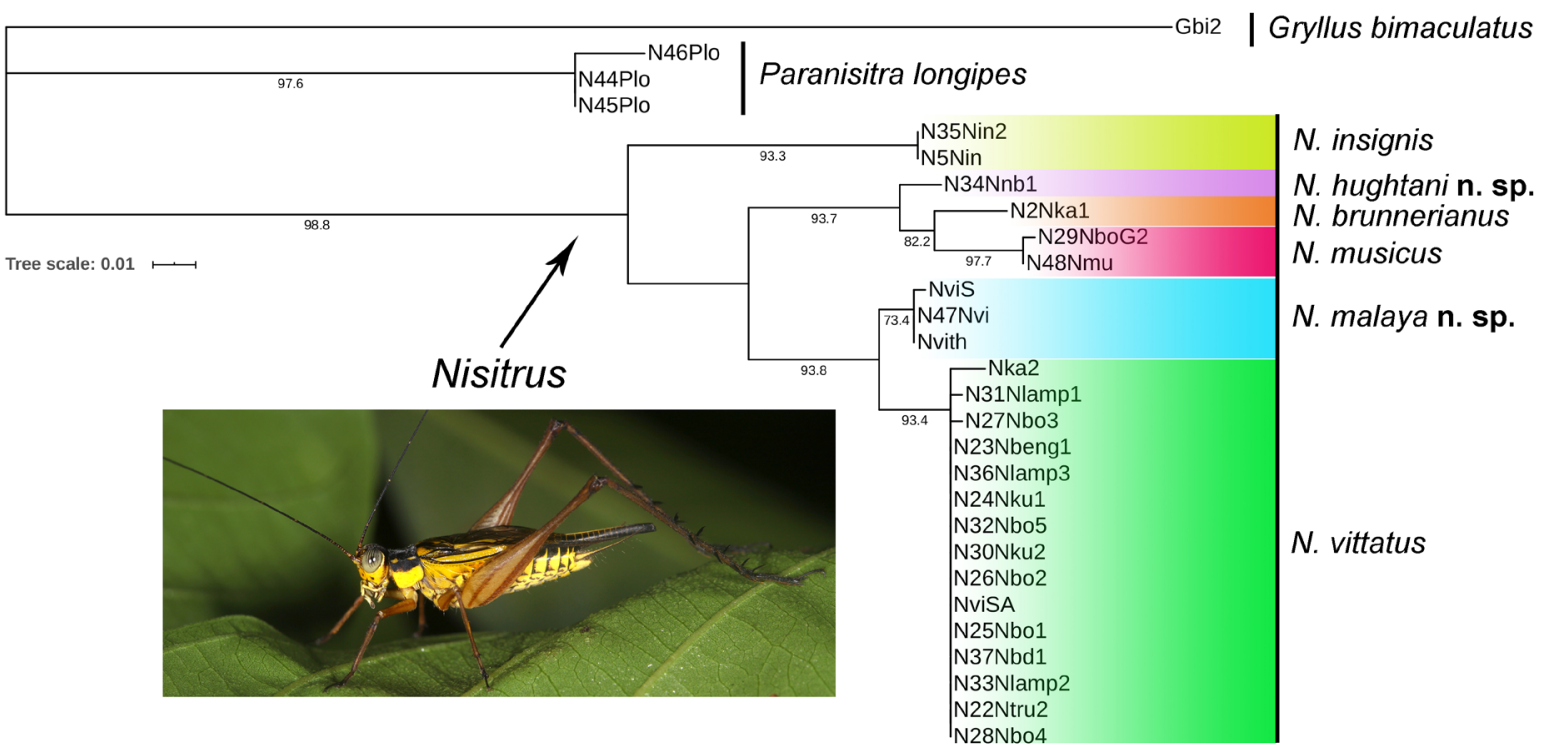

Fig. 6. Maximum likelihood phylogenetic tree based on the 12S marker of six species of Nisitrus Saussure, 1878. Values under branches indicate bootstrap values. 


\title{
Systematic part
}

\author{
Class Insecta Linnaeus, 1758 \\ Order Orthoptera Latreille, 1793 \\ Suborder Ensifera Chopard, 1920 \\ Superfamily Grylloidea Laicharting, 1781 \\ Family Gryllidae Laicharting, 1781 \\ Subfamily Eneopterinae Saussure, 1874 \\ Tribe Nisitrini Robillard, 2004
}

Genus Nisitrus Saussure, 1878

Nisitra Walker, 1869: 91.

Nisitra-Chopard 1940: 199.

Nisitrus - Saussure 1878: 511, 522 (nomen novum for Nisitra Walker). — Chopard 1968: 352. — Desutter-Grandcolas 1990: 239. — Otte 1994: 67. — Preston-Mafham 2000: 2241 (behaviour). Robillard \& Desutter-Grandcolas 2004a: 276; 2004b: 578; 2004c: 304; 2006: 644; 2008: 67 (Nisitrini tribe); 2011: 637. — Robillard et al. 2007: 1265. - Desutter-Grandcolas et al. 2010: 616. — Nattier et al. 2011: 2201 (phylogeny and molecular dating). - Robillard \& Tan 2013: 707 (redescription and diagnosis). - Vicente et al. 2017: 2203 (phylogeny, historical biogeography). - Cigliano et al. 2020 (Orthoptera Species File Online).

\section{Type species}

Nisitra vittatus (Haan, 1844).

\section{Remarks on type species}

Kirby (1906) and Chopard (1968) listed N. vittata as the type species of Nisitra and treated the original type species $N$. marginata Walker, 1869 as a synonym of $N$. vittata. Subsequent authors listed $N$. vittatus as the type species of the replacement name Nisitrus, although Otte (1994) reinstated N. marginatus as a valid species (Braun 2013 in Cigliano et al. 2020). The present revision revalidates the synonymy of $N$. marginatus under $N$. vittatus, making $N$. vittatus the valid type species of the genus.

Diagnosis (emended from Robillard \& Tan 2013)

Among genera of Eneopterinae, Nisitrus is characterised by an elegant, wasp-like, slender and colourful body (Figs 7-9). Size average for subfamily. Colouration vivid, dominantly yellow, whitish and black, with species-specific patterns, particularly in the head (Figs 10-11), pronotum (Figs 11-12) and FWs (Figs 12-14). Characteristic head shape with narrow fastigium and large prominent eyes with thin dorso-ventral black stripes. Pronotum setose, square-shaped to slightly trapezoidal, usually bisinuated posteriorly. Metanotum with large glandular structures in males, made of a wide pit on scutum and a pair of posterior pits on scutellum, with glandular pores mostly organised by groups of 2 or 3 (Fig. 15). FWs more or less as long as abdomen. Male Nisitrus show modified FW venation and characteristic glossy transparency. Hindwings longer than FWs, bicoloured in most species, their base transparent with a wide dark posterior margin. Legs long and thin, FIII with a characteristic narrowed area before knee. Other general traits: TI with two tympana, inner one slit-like, covered by a swollen cuticular expansion; outer tympanum oval, its membrane transversally plicate in dorsal half. TI with three apical spurs; outer dorsal spur missing. TII with four apical spurs, inner longest. TIII with three inner and three outer apical spurs, median longest on each side; four pairs of subapical spurs, inner and outer spurs almost straight, their apex hook-like; TIII serrulate over whole length, slightly furrowed dorsally. Tarsomeres III-1 with one row of dorsal spines on external edge in addition to apical spines. Apical claws of legs slightly indented. Both males and females show characteristic genitalia. 


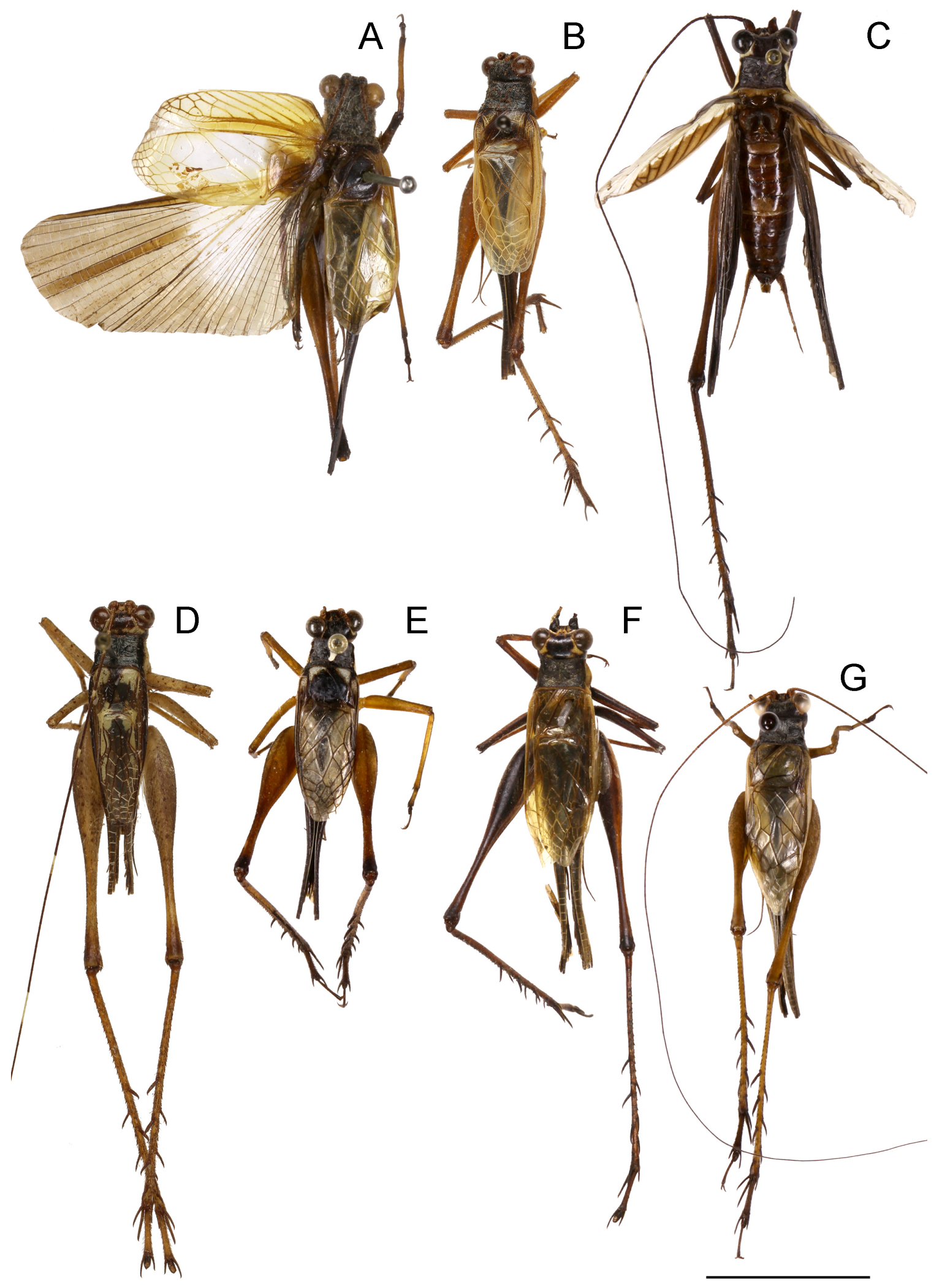

Fig. 7. Habitus of $\widehat{\partial} \partial^{\lambda}$ in dorsal view. A. Nisitrus brunnerianus Saussure, 1878. B. N. crucius Robillard \& Tan sp. nov. C. N. hughtani Robillard \& Tan sp. nov. D. N. insignis Saussure, 1878. E. N. malaya Robillard \& Tan sp. nov. F. N. musicus Ingrisch, 1987. G. N. vittatus (Haan, 1844). Scale bar $=10 \mathrm{~mm}$. 

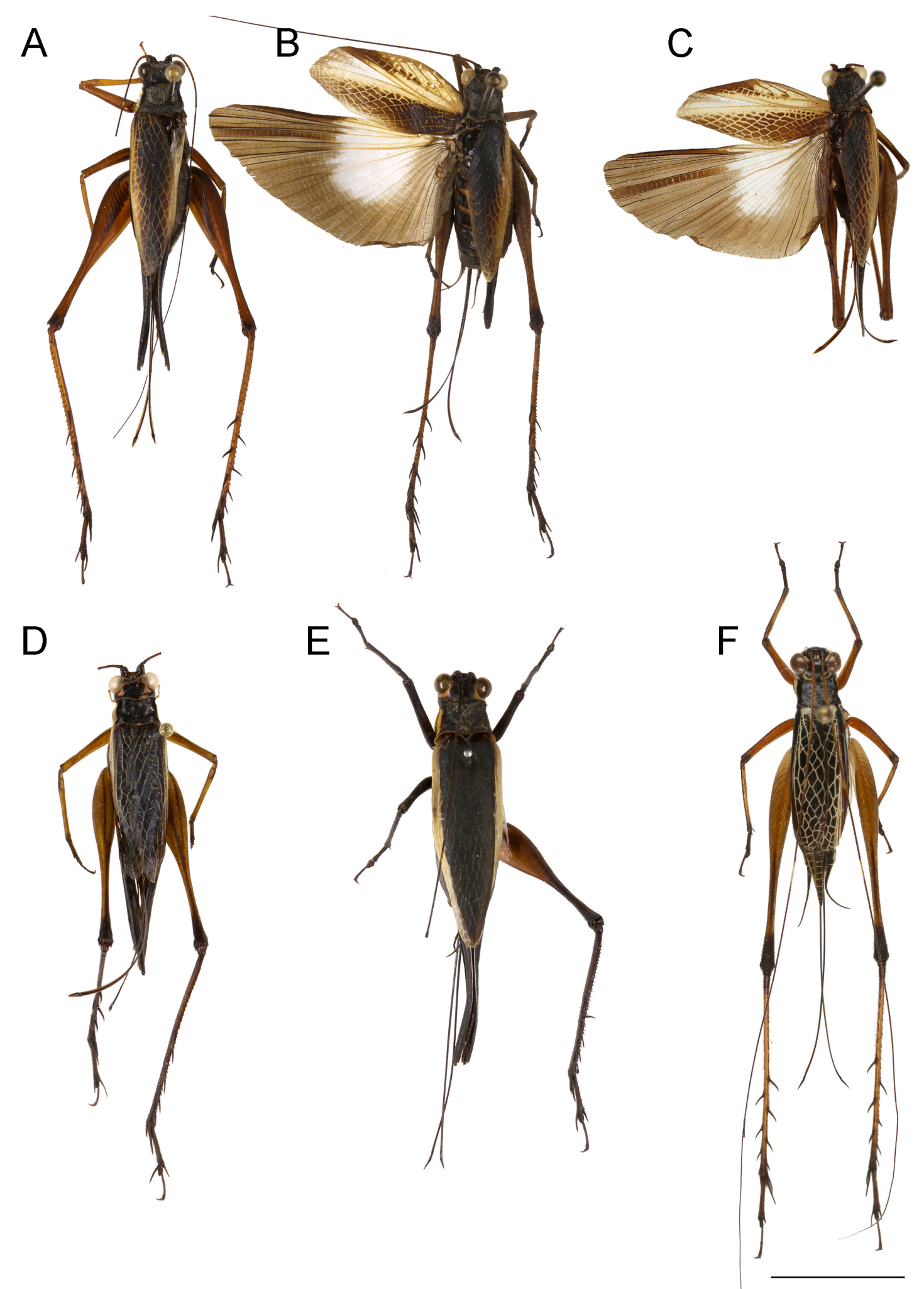

Fig. 8. Habitus of $q Q$ in dorsal view. A-B. Nisitrus brunnerianus Saussure, 1878. C. N. crucius Robillard \& Tan sp. nov. D. N. danum Robillard \& Tan sp. nov. E. N. hughtani Robillard \& Tan sp. nov. F. $N$. insignis Saussure, 1878. Scale bar $=10 \mathrm{~mm}$. 


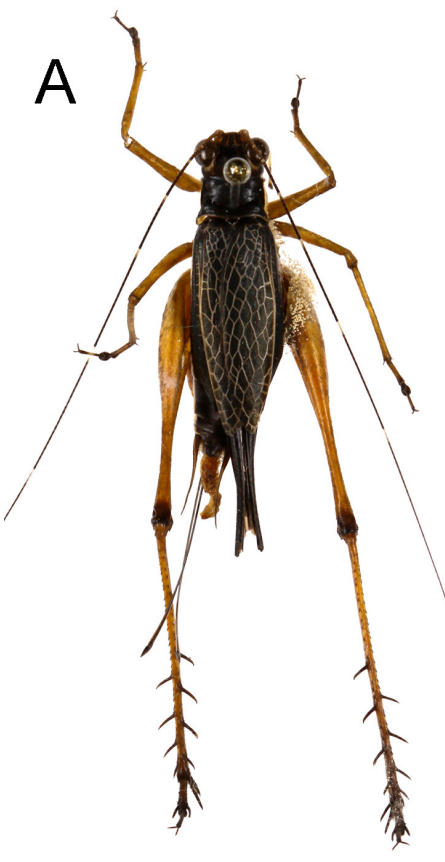

B
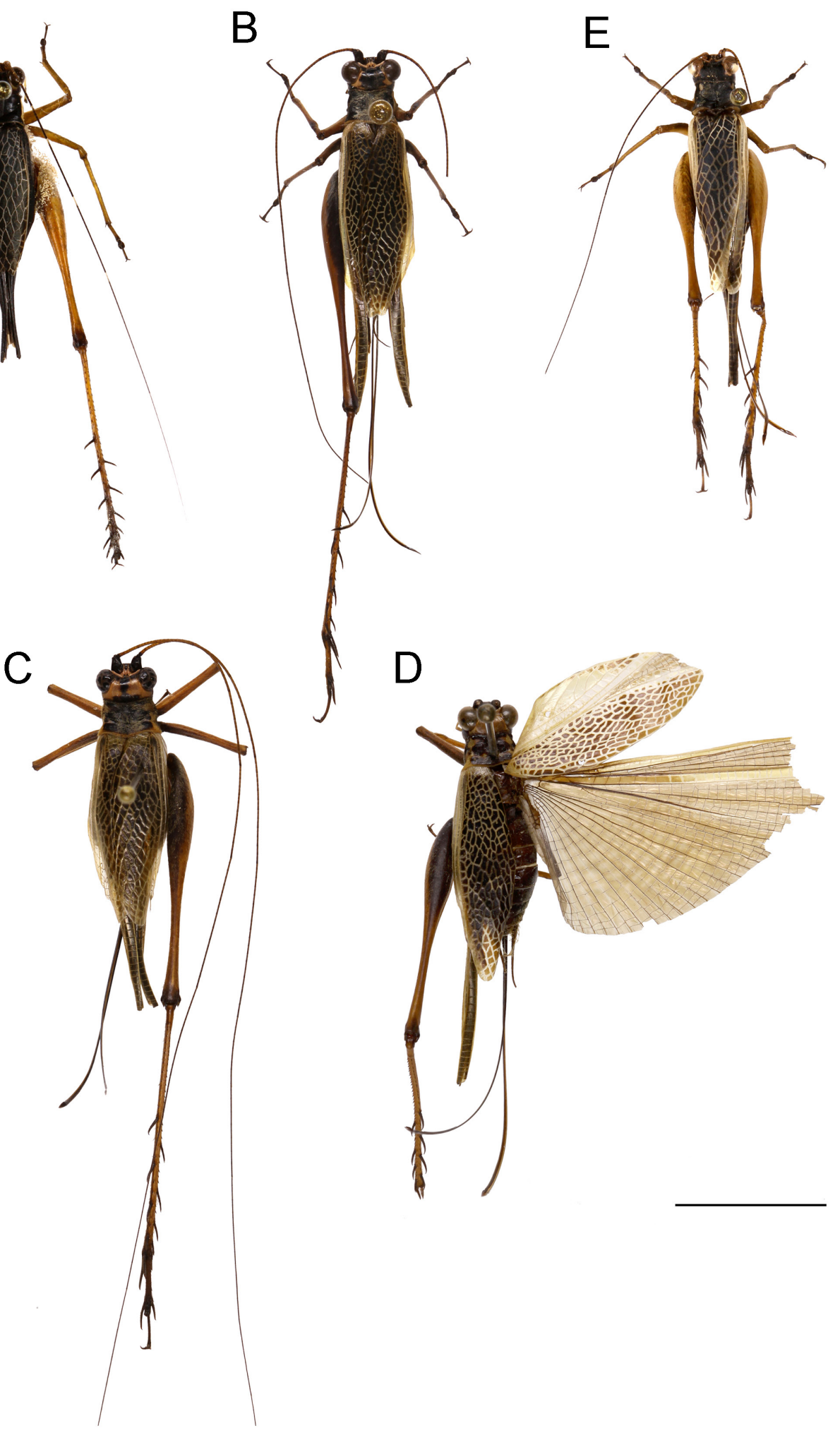

Fig. 9. Habitus of $q \propto$ in dorsal view. A. Nisitrus malaya Robillard \& Tan sp. nov. B. N. musicus Ingrisch, 1987. C-D. N. rindu Robillard \& Tan sp. nov. E. N. vittatus (Haan, 1844). Scale bar $=10 \mathrm{~mm}$. 

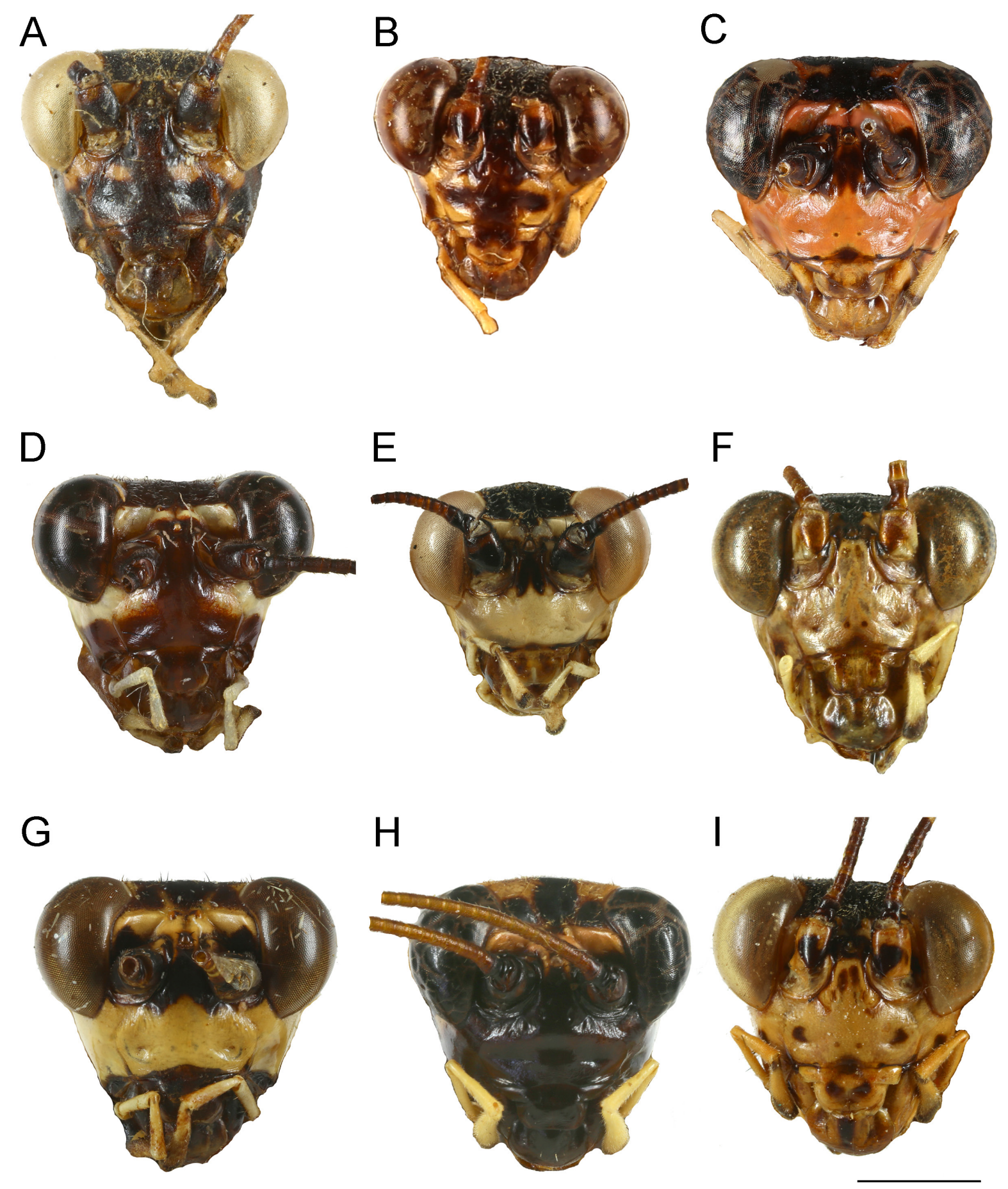

Fig. 10. Face in anterior view. A. Nisitrus brunnerianus Saussure, 1878. B. N. crucius Robillard \& Tan sp. nov. C. N. danum Robillard \& Tan sp. nov. D. N. hughtani Robillard \& Tan sp. nov. E. N. insignis Saussure, 1878. F. N. malaya Robillard \& Tan sp. nov. G. N. musicus Ingrisch, 1987. H. N. rindu Robillard \& Tan sp. nov. I. $N$. vittatus (Haan, 1844). Scale bar $=2 \mathrm{~mm}$. 

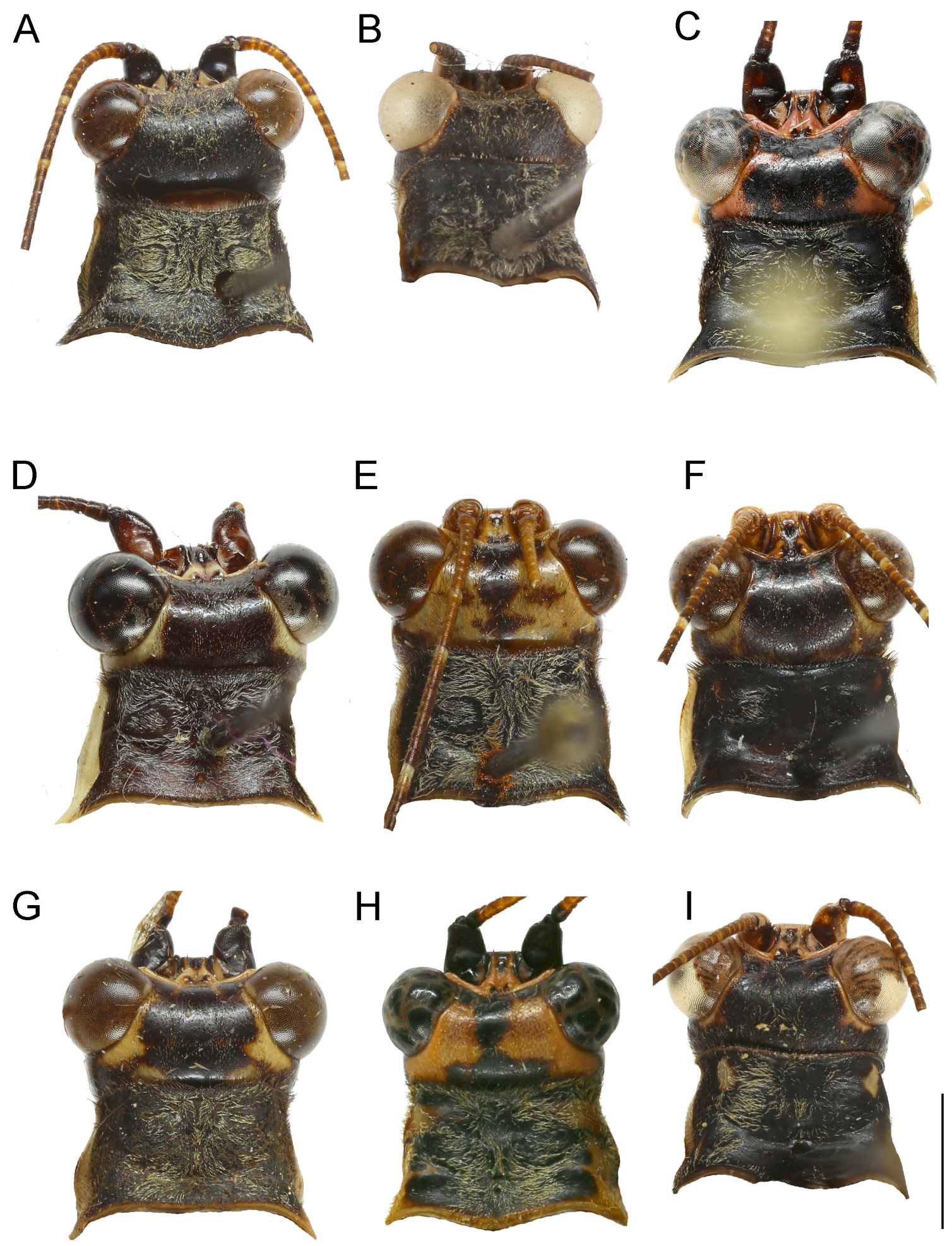

Fig. 11. Head and pronotum in dorsal view. A. Nisitrus brunnerianus Saussure, 1878. B. N. crucius Robillard \& Tan sp. nov. C. N. danum Robillard \& Tan sp. nov. D. N. hughtani Robillard \& Tan sp. nov. E. N. insignis Saussure, 1878. F. N. malaya Robillard \& Tan sp. nov. G. N. musicus Ingrisch, 1987. H. $N$. rindu Robillard \& Tan sp. nov. I. $N$. vittatus (Haan, 1844). Scale bar $=2 \mathrm{~mm}$. 

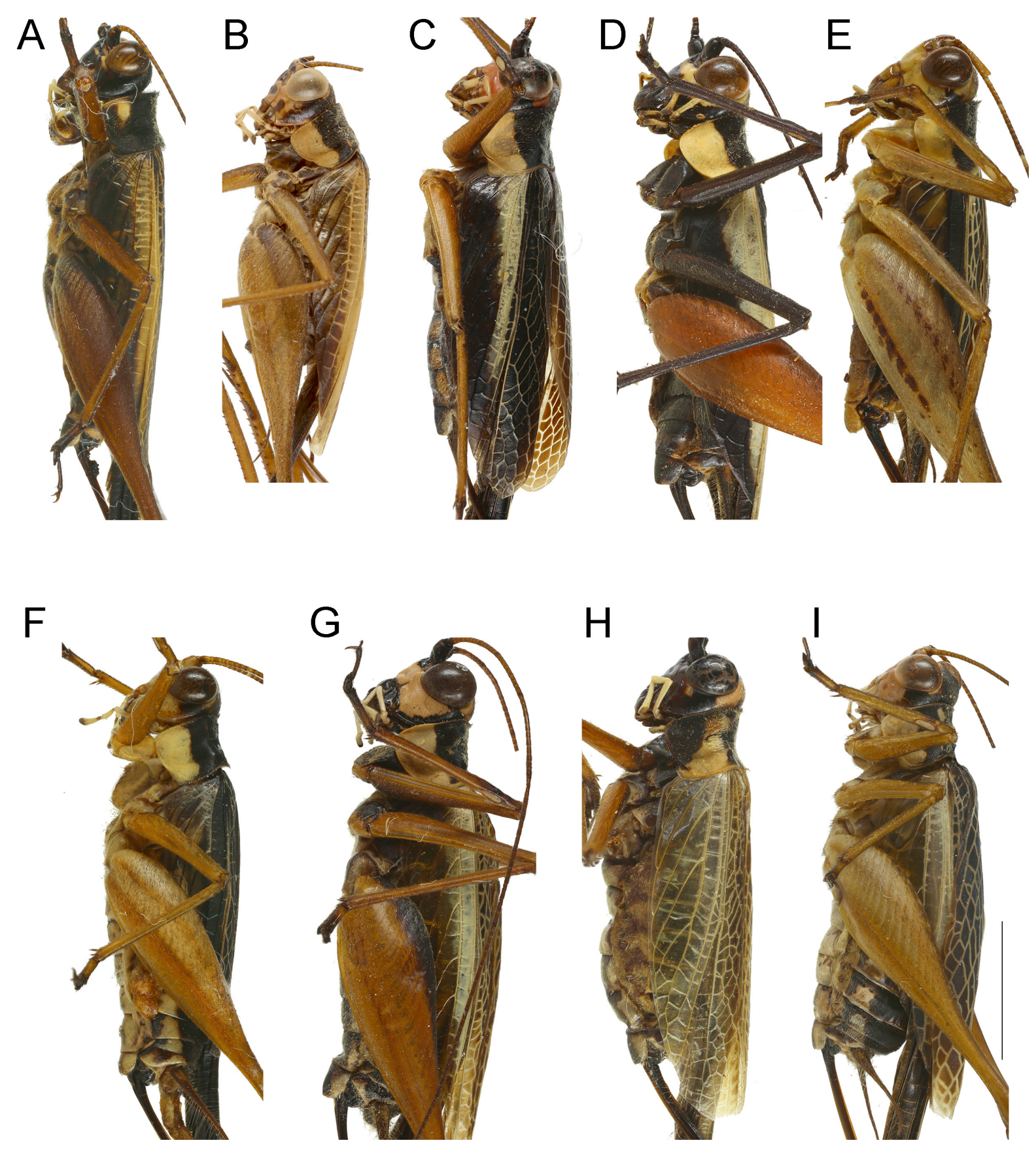

Fig. 12. Body in lateral view. A. Nisitrus brunnerianus Saussure, 1878. B. N. crucius Robillard \& Tan sp. nov. C. N. danum Robillard \& Tan sp. nov. D. N. hughtani Robillard \& Tan sp. nov. E. N. insignis Saussure, 1878. F. N. malaya Robillard \& Tan sp. nov. G. N. musicus Ingrisch, 1987. H. $N$. rindu Robillard \& Tan sp. nov. I. N. vittatus (Haan, 1844). Scale bar $=5 \mathrm{~mm}$. 


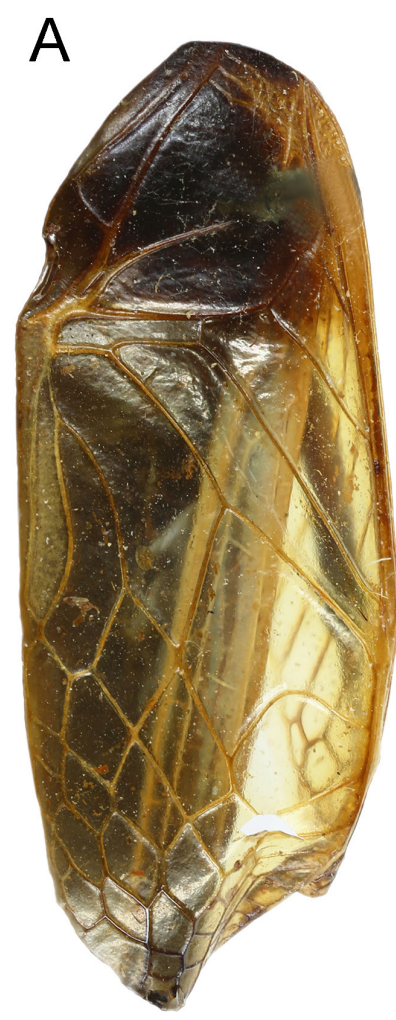

B

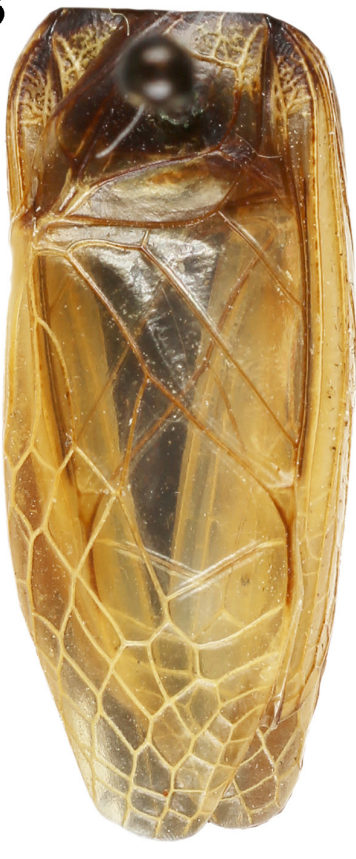

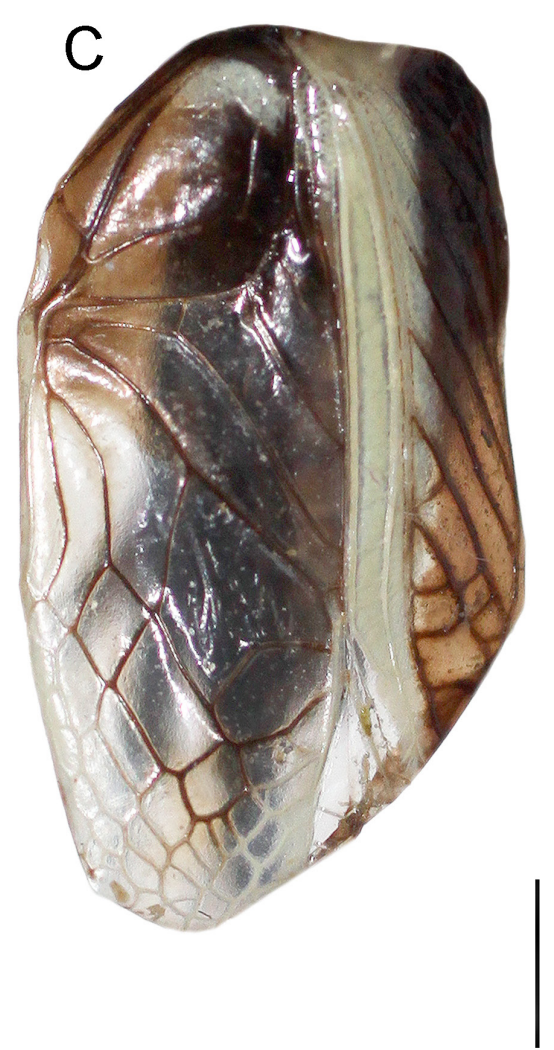

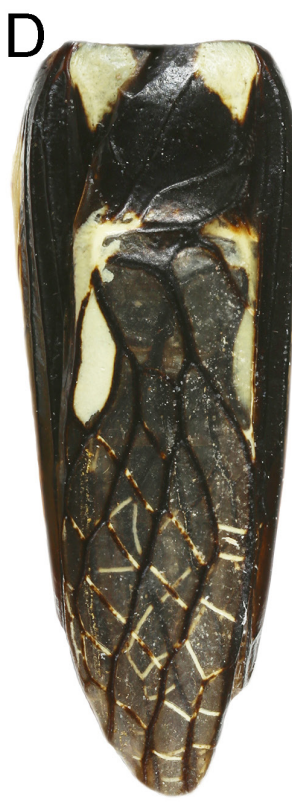

$E$

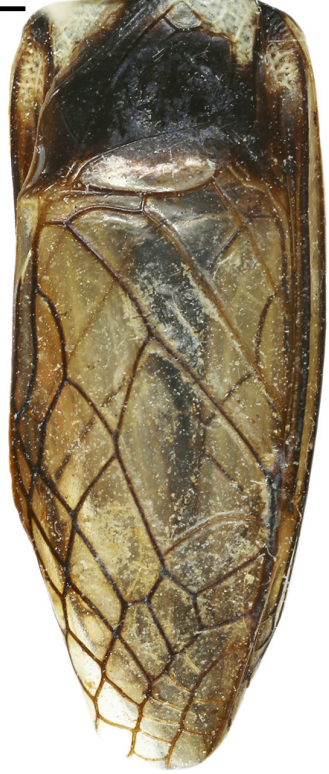

$\mathrm{F}$

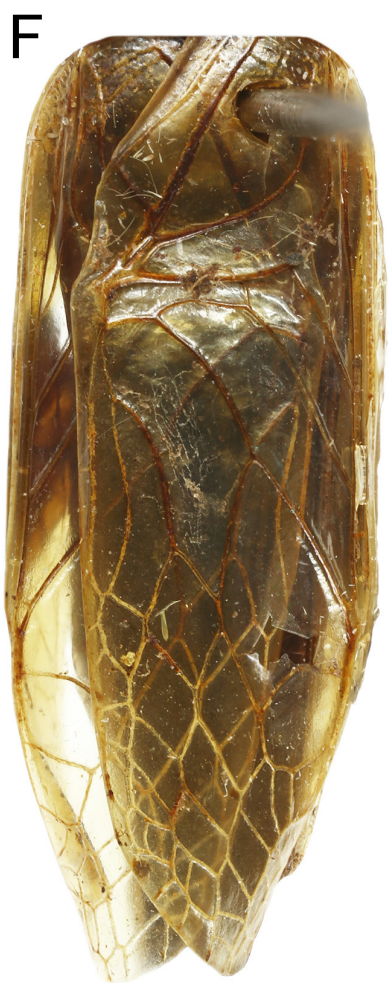

G

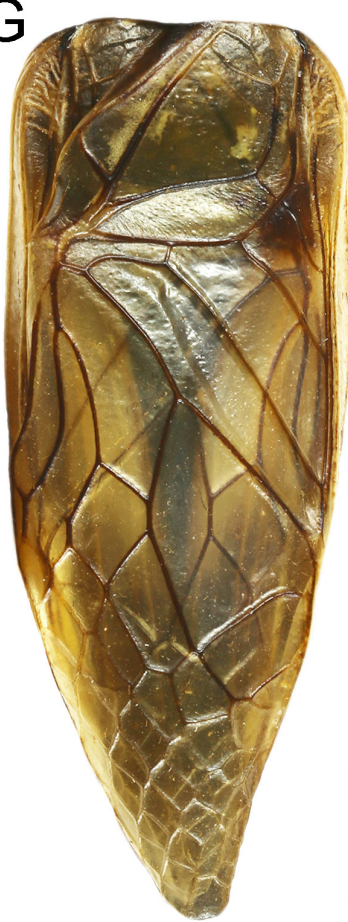

Fig. 13. Male tegmina in dorsal view. A. Nisitrus brunnerianus Saussure, 1878. B. N. crucius Robillard \& Tan sp. nov. C. N. hughtani Robillard \& Tan sp. nov. D. N. insignis Saussure, 1878. E. N. malaya Robillard \& Tan sp. nov. F. N. musicus Ingrisch, 1987. G. N. vittatus (Haan, 1844). Scale bar $=2 \mathrm{~mm}$. 

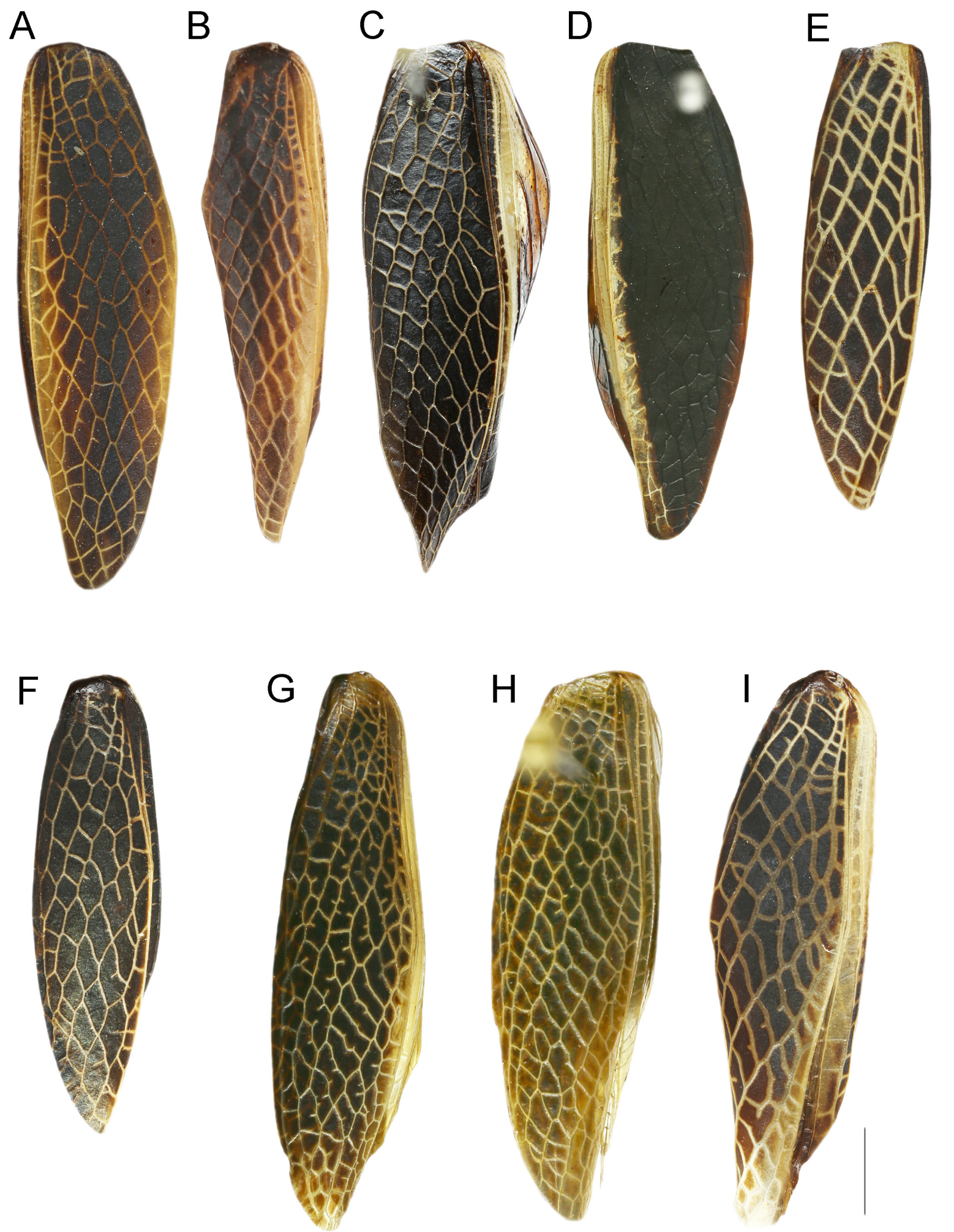

Fig. 14. Female tegmina in dorsal view. A. Nisitrus brunnerianus Saussure, 1878. B. N. crucius Robillard \& Tan sp. nov. C. N. danum Robillard \& Tan sp. nov. D. N. hughtani Robillard \& Tan sp. nov. E. N. insignis Saussure, 1878. F. N. malaya Robillard \& Tan sp. nov. G. N. musicus Ingrisch, 1987. H. $N$. rindu Robillard \& Tan sp. nov. I. $N$. vittatus (Haan, 1844). Scale bar $=2 \mathrm{~mm}$. 
Male genitalia (Fig. 16) with membranous and setose lophi well individualised; pseudepiphallic parameres including two membranous posterior lobes and a sclerotized anterior lobe oriented anteriorly toward median axis of genitalia and carrying a secondary preapical sclerotized lobe; ectophallic arc transverse, incomplete due to a little-sclerotized median area; ectophallic fold narrowed preapically, its apex narrow, located between anterior apex of pseudepiphallic parameres; dorsal part of fold sclerotized, forming two elongated sclerites connected to the median area of arc; ventral part of ectophallic fold membranous, with two strong rounded lateral sclerites of variable shapes. Membrane of endophallic cavity smooth. Female copulatory papilla (Fig. 17) conical, apex generally sclerotized and pointed. Ovipositor typically longer than FIII; apex thin with both dorsal and ventral edges smooth.

\section{Phylogenetic relationships}

Based on previous phylogenetic studies (Robillard \& Desutter-Grandcolas 2004c; Nattier et al. 2011; Vicente et al. 2017), Nisitrus is the sister genus of Paranisitra Chopard, 1925 (revision in Gorochov 2009 and Baroga-Barbecho et al. 2019). The two genera form the Nisitrini tribe (Robillard \& DesutterGrandcolas 2008) and are very close morphologically; Paranisitra is mostly characterised by a lack of wings in both sexes, but except for this, it shares with Nisitrus its general body shape, long thin legs with indented claws, colouration with yellow and black, head shape with large prominent eyes and narrow fastigium, and the general structure of male and female genitalia. Nisitrini are less easy to relate to other clades of Eneopterinae.

\section{Natural history}

Species tend to be found at forest edges and gaps in the forest where the vegetation is more exposed. They are also found among shrubs and herbaceous plants (but not grasses). Nisitrus are observed to be generally diurnal, during which the males can be heard calling and individuals are found foraging in the vegetation. It seems as Nisitrus are mostly herbivorous, feeding on leaves, but also on flowers (Tan et al. 2017). Nisitrus are also observed to congregate with one another on the same plant, sometimes making up of more than 20 individuals of both adults and nymphs. They can be considered a pest in some parts of Southeast Asia (Willemse 2001).

\section{Included species}

Nisitrus brunnerianus from Borneo and Java; $N$. crucius sp. nov. and $N$. danum sp. nov. (both from Borneo); N. hughtani sp. nov. from Sumatra; N. hyalinus from Borneo; N. insignis from Sumatra and Malay Peninsula; N. malaya sp. nov. from Malay Peninsula; N. musicus and N. rindu sp. nov. from Borneo; and N. vittatus from Sumatra and Borneo.
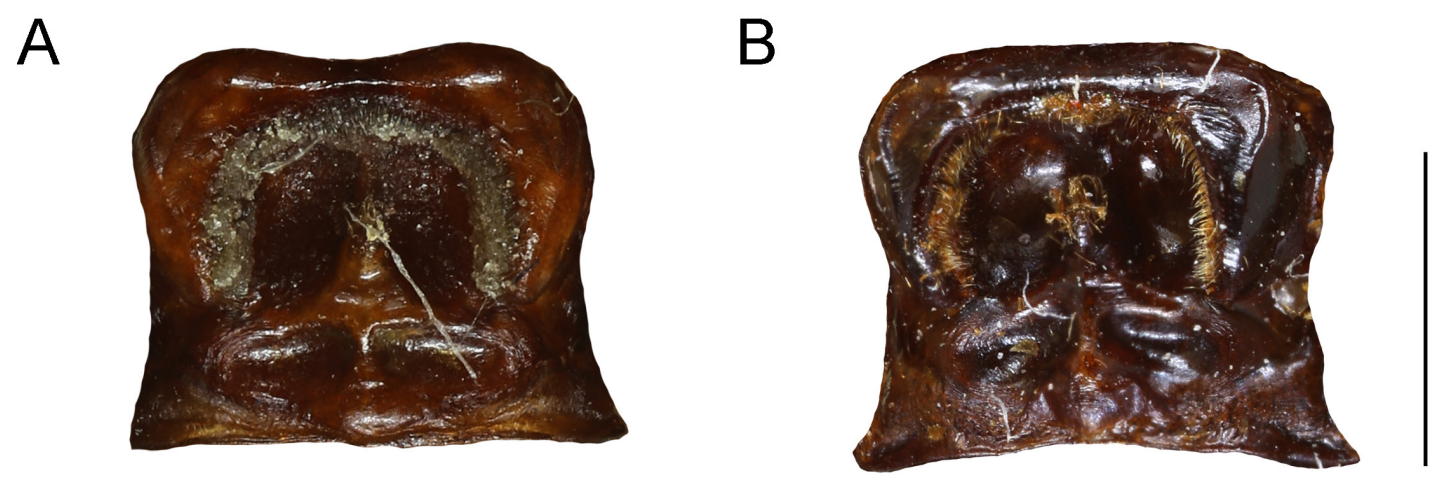

Fig. 15. Metanotal gland. A. Nisitrus hughtani Robillard \& Tan sp. nov. B. N. brunnerianus Saussure, 1878. Scale bar $=2 \mathrm{~mm}$. 

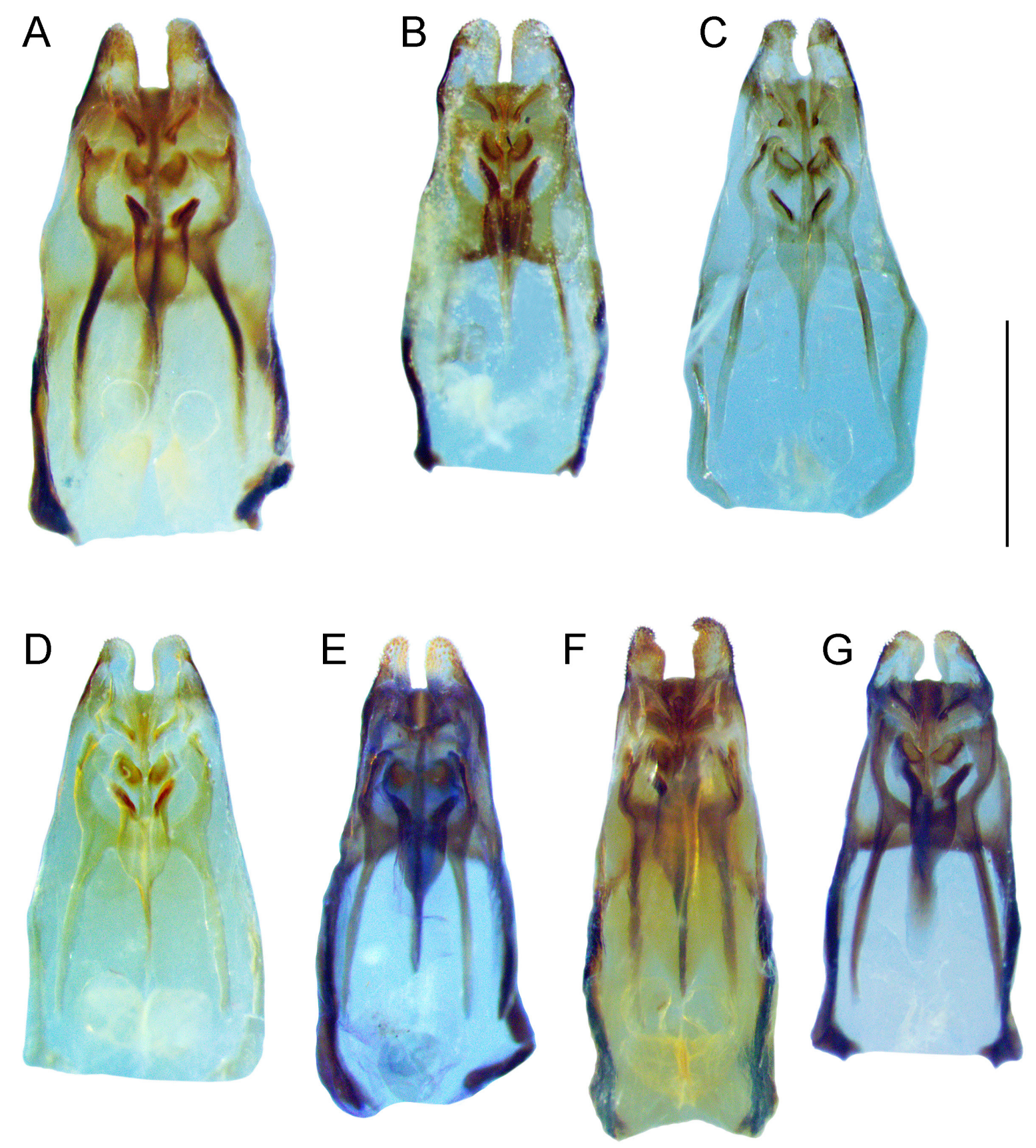

Fig. 16. Male genitalia in ventral view. A. Nisitrus brunnerianus Saussure, 1878. B. N. crucius Robillard \& Tan sp. nov. C. N. hughtani Robillard \& Tan sp. nov. D. N. insignis Saussure, 1878. E. N. malaya Robillard \& Tan sp. nov. F. N. musicus Ingrisch, 1987. G. N. vittatus (Haan, 1844). Scale bar $=1 \mathrm{~mm}$. 

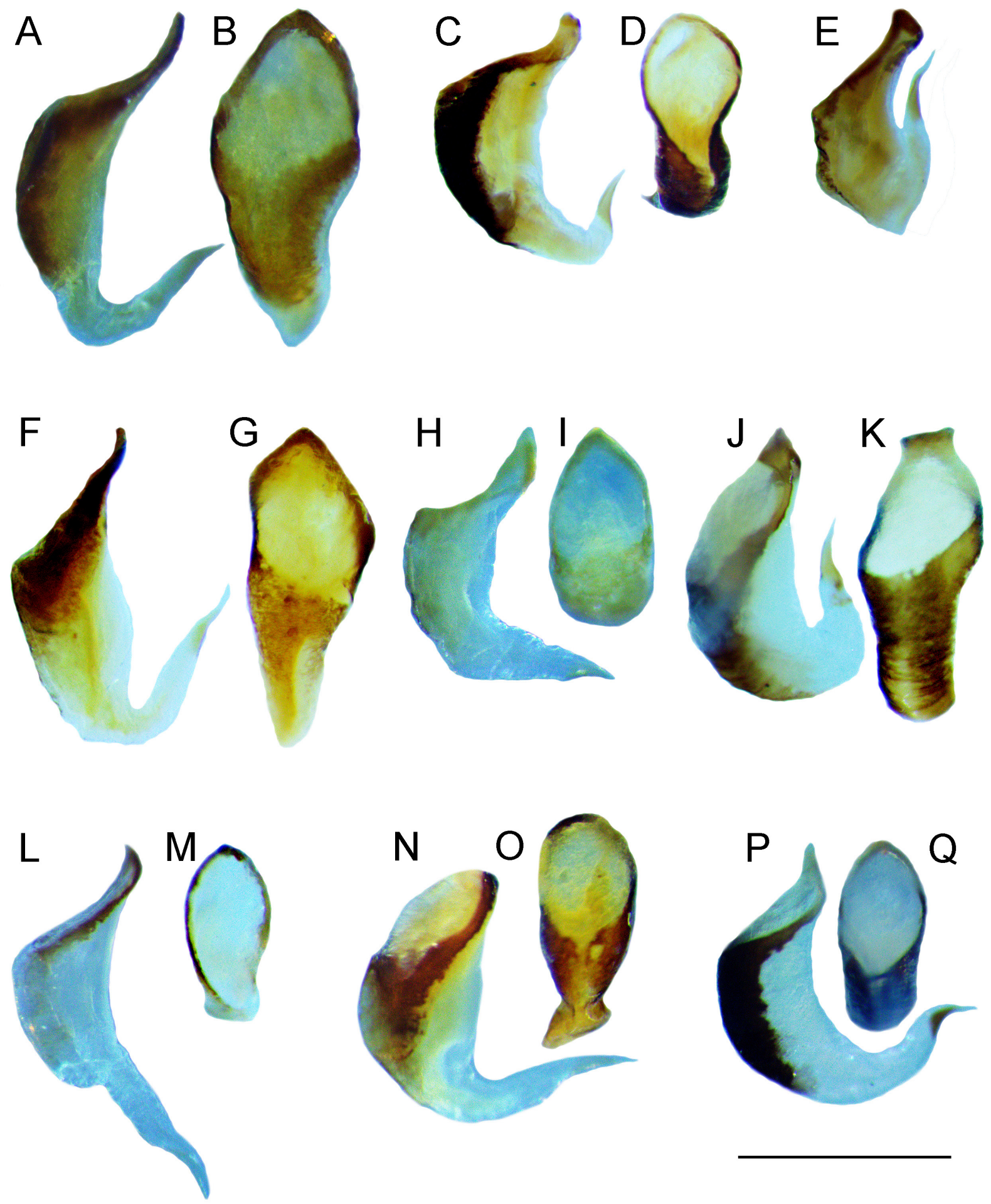

Fig. 17. Female genitalia in lateral (A, C, E, F, H, J, L, N, P) and dorsal (B, D, G, I, K, M, O, Q) views. A-B. Nisitrus brunnerianus Saussure, 1878. C-D. N. crucius Robillard \& Tan sp. nov. E. N. danum Robillard \& Tan sp. nov. F-G. N. hughtani Robillard \& Tan sp. nov. H-I. N. insignis Saussure, 1878. J-K. N. malaya Robillard \& Tan sp. nov. L-M. N. musicus Ingrisch, 1987. N-O. N. rindu Robillard \& Tan sp. nov. P-Q. N. vittatus (Haan, 1844). Scale bar $=0.5 \mathrm{~mm}$. 


\section{Distribution}

Borneo (Sabah and Sarawak States of East Malaysia, Brunei Darussalam, and Kalimantan State of Indonesia), Java, Malay Peninsula (Peninsular Malaysia and Singapore) and Sumatra (Indonesia) (Fig. 5).

\section{Key to the species of Nisitrus Saussure, 1878}

1. Frons mostly black, or with large dark markings (e.g., cross-shaped pattern); gena usually black, although may have yellow band ventral of eye

- Frons mostly yellow, sometimes with small dots but without large dark markings; gena usually yellow

2. FW with longitudinal white stripe around region of $\mathrm{CuA}, \mathrm{M}$ and $\mathrm{R}$ with a distinct margin from black colouration on dorsal field; lateral field usually infumated black ventrally. Distribution: Sumatra N. hughtani Robillard \& Tan sp. nov.

- FW with longitudinal white stripe around region of $\mathrm{CuA}, \mathrm{M}$ and $\mathrm{R}$ darkens progressively towards the dorsal field without a distinct margin from black colouration on dorsal field; lateral field usually light coloured or transparent ventrally. Distribution: Borneo and Java

3. Smaller in size, female FWL typically $<11.3 \mathrm{~mm}$. Frons with a characteristic black cross marking N. crucius Robillard \& Tan sp. nov.

- Larger in size, female FWL typically $>11.8 \mathrm{~mm}$. Frons completely black; without a characteristic black cross marking

4. Dorsum of head completely black. Pronotal lateral lobe either with ventral half yellow or with an oval yellow spot at the anterior end

N. brunnerianus Saussure, 1878

- Dorsum of head pale with some dark markings. Pronotal lateral lobe with a characteristic dorsal yellow band that extends ventrally $\boldsymbol{N}$. rindu Robillard \& Tan sp. nov.

5. Frons with black band between eyes, mouthparts mostly yellow. Body darker; female FW typically with infumated black cells, with lateral parts of dorsal field usually with an infumated yellow longitudinal stripe. Distribution: Borneo (Sabah)

N. danum Robillard \& Tan sp. nov.

- Frons without black band between eyes, mouthparts black. Body usually with more yellow colouration; male FW with some black and white infumation, but generally transparent. Distribution: Borneo, Malay Peninsula and Sumatra

6. Legs usually pale in colouration; FIII with at least one black longitudinal stripe on external face. Male FW with distinct infumated white spots and infumated black pattern near base, sometimes with infumated white patterns around chords, but otherwise transparent, harp very small, with one distinct straight oblique vein; female FW almost always with yellow/white veins. Distribution: Sumatra

N. insignis Saussure, 1878

- Legs usually brown in colouration; FIII with faint or without black longitudinal stripe on external face. Male FW with infumated black pattern near base, sometimes with infumated white spots, but otherwise transparent, harp larger, with 3 oblique veins; female FW sometimes with yellow/white veins. Distribution: Sumatra, Borneo, Malay Peninsula

7. Eyes dark when alive. Frons yellow, face part of fastigium (including scapes) and mouthparts black, maxillary palpi yellow; dorsal part of legs black. Male pseudepiphallus slender. Distribution: Borneo, near Kinabalu area

N. musicus Ingrisch, 1987

- Eyes green when alive. Frons yellow to brown, mouthparts sometimes yellow or brown; legs typically homogenous brown. Pseudepiphallus more robust, broad. Distribution: Sumatra, Borneo, Malay Peninsula 
8. Lighter in colouration. Lateral field of FWs usually light in colouration. Juveniles of pale white colouration with numerous dark stripes all around the body. Female copulatory papilla without truncated lobule at the ventro-anterior end. Distribution: Borneo, Sumatra

N. vittatus (Haan, 1844)

- Darker in colouration. Lateral field of FWs usually dark in colouration. Juveniles of darker colouration, usually grey, their pronotum without longitudinal stripes but dorsal disk sometimes with a large velvety black spot. Female copulatory papilla with a truncated lobule at the ventro-anterior end. Distribution: Malay Peninsula N. malaya Robillard \& Tan sp. nov.

Nisitrus brunnerianus Saussure, 1878

Figs 5, 7A, 8A-B, 10A, 11A, 12A, 13A, 14A, 15B, 16A, 17A-B, 18; Tables 1-3

Nisitrus brunnerianus Saussure, 1878: 516.

Nisitra brunnerianus - Kirby 1906: 87.

Nisitrus brunnerianus - Chopard 1968: 353. — Cigliano et al. 2020 (Orthoptera Species File online). Nisitrus aff. brunnerianus - Vicente 2017: 2203 (phylogeny, historical biogeography).

non Nisitrus brunnerianus - Robillard \& Desutter-Grandcolas 2004a: 276 (morphological phylogeny).

\section{Diagnosis}

This species differs from all known congeners by the following characters: head nearly completely black (sometimes with yellow patch beneath scapes and eyes). Pronotum lateral lobe either black with small brown spot on postero-ventral corner, or black in dorsal half and yellow in ventral half. Male FW with basal area brown with tint of black, otherwise mostly hyaline; veins mostly yellow. Female FW with dorsal field mostly infumated black, with veins dark brown and lighten towards lateral field and apical areas. Legs red brown; FIII black dorso-basally without bands or stripes on external surface; with a distinct black ring before hind knee; hind knee black. Abdomen with tergites black, sternites mostly black. This species is similar to $N$. crucius sp. nov. and $N$. rindu sp. nov. but differs by the combination of these characters: frons nearly completely black (without black cross marking as in $N$. crucius sp. nov.), dorsum of head completely black (vs with yellow margins in $N$. crucius sp. nov. or pale with dark patterns in $N$. rindu sp. nov.) and lateral lobe either with ventral half yellow or with an oval yellow spot at the anterior end (vs with a characteristic dorsal yellow band that extends ventrally in N. rindu sp. nov.).

\section{Material examined}

Lectotype (here designated)

NO COUNTRY • +; "Boncard ded.”; Brunner von Wattenwyl leg.; NMW.

Paralectotype (here designated)

NO COUNTRY • 1 क ; same collection data as for lectotype; NMW.

\section{Additional specimens}

INDONESIA - Kalimantan • 1 \%; [East Kalimantan] "West Borneo, Marah", [near border of Koetai and Beraoe]; $1^{\circ} 42^{\prime} 28^{\prime \prime}$ N, $116^{\circ} 15^{\prime} 40^{\prime \prime}$ E; 10 Aug. 1925; H.C. Siebers leg.; MNHN • 1 ○े; [East Kalimantan] "West Borneo, Marah"; 058'31" N, 116³3'14.8" E; 10-28 Nov. 1925; H.C. Siebers leg.; MNHN-EOENSIF1734 7 우; same collection data as for preceding; MNHN • 2 q $O$; "West Borneo, Midden", [near

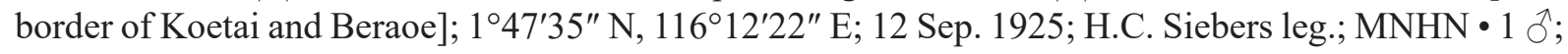
"West Borneo, Midden", [near border of Koetai and Beraoe]; 1 ${ }^{\circ} 50^{\prime} 14^{\prime \prime}$ N, 116 $16^{\circ} 34^{\prime \prime}$ E; 26 Sep. 1925; H.C. Siebers leg.; MNHN-EO-ENSIF1726 • 1 ○’; "West Borneo, Midden", [near Beraoe?]; 1 ${ }^{\circ} 58^{\prime} 53^{\prime \prime}$ N, $116^{\circ} 7^{\prime} 56^{\prime \prime}$ E; 1 Oct. 1925; H.C. Siebers leg.; MNHN-ENSIF1752 • 1 ô; same collection data as for 


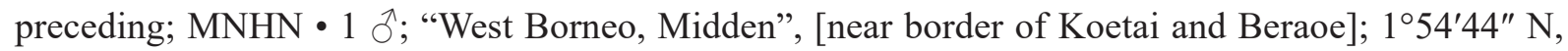
$116^{\circ} 11^{\prime 2} 27^{\prime \prime}$ E; 6 Nov. 1925; H.C. Siebers leg.; MNHN-ENSIF1715 • 2 우; same collection data as for preceding; MNHN • 1 \%; [Melawi Regency] "West Borneo, Melawi”; 0॰35'43" S, 00'46" E; Nov.Dec. 1924; Blanchemanche leg.; MNHN • 1 O; "West Borneo"; 1924; Blanchemanche leg.; MNHN - 1 क; "Lebang Hara"; 25 Nov.-5 Dec. 1924; H. Winkler leg.; ZMH • 1 क; "Samarinda"; 0²9'47" S, $117^{\circ} 8^{\prime 2} 23^{\prime \prime}$ E; M.-E. Walsh leg.; ZMLU • 1 q; Kayan Basin, Bahau; 255'23.2" N, 117³3'13.1" E; 13 Nov.

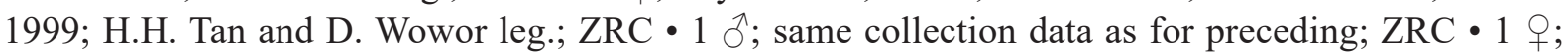
“O. Borneo Pelawan”; May 1937; M.-E. Walsh leg.; ZMLU • 4 우; Penda Siroen, Soengai Maroewai [Sungai Maruwai]; 0³4'1.9" S, 11444'0.5" E; 13 May 1932; Prince Leopold leg.; RBINS • 1 क; same collection data as for preceding; RBINS • 1 \% ; Kumai, West Kotawaringin Regency, Central Kalimantan; $2^{\circ} 55^{\prime} 17.9^{\prime \prime}$ S, 111 ${ }^{\circ} 54^{\prime} 16.4^{\prime \prime}$ E; 24 Jun. 2014; G. Cahyadi leg.; iNaturalist.org/observations/41219515. -

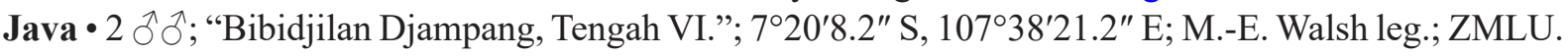

MALAYSIA - Sarawak • 1 \%; Balleh River, Kapit jungle; $1^{\circ} 45^{\prime} 14.51^{\prime \prime}$ N, $113^{\circ} 45^{\prime} 59.00^{\prime \prime}$ E; 15 Apr. 1979; PII: N53; MNHN-EO-ENSIF11260 • 2 q o+; Balleh River, Kapit jungle; $1^{\circ} 45^{\prime} 14.51^{\prime \prime}$ N, $113^{\circ} 45^{\prime} 59.00^{\prime \prime}$ E;

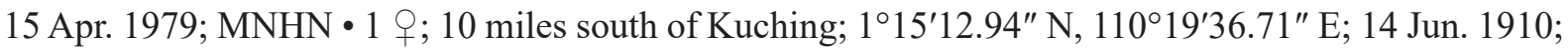
Beebe leg.; MZB • 1 juvenile; "Gunung Mulu NP, Camp 4, Summit Trail”; 4²'40.6" N, 11454'50.8" E; 5950 ft a.s.l.; 19 Jan. 2009; G.J. Svenson leg.; MNHN • 1 क; Sarawak; 1909; C.J. Brooks leg.; NHMUK 012497567 • 1 \%; [Semongoh] "Semongok, on oil palm”; 1²3'51" N, 110¹8'43" E; 19 Dec. 1966; "Salin Iuses” leg.; NHMUK 012497569.

NO COUNTRY • 1 q; "Borneo"; [19]32; "Weir” leg.; AMS-K393086 • 1 क; "Borneo"; 1891; Chopard leg.; MNHN• 1 क; "Federal Malay States”; 1909; C.J. Brooks leg.; NHMUK 012497568.

\section{Redescription}

Relatively large and slender (Figs 7A, 18). Vertex completely black (Fig. 11A). Fastigium velvety black, with anterior margins yellow. Scapes black, posterior end red brown. Antennae red brown with some segments black and with wide whitish rings. Eyes dark green when alive and red brown when dried. Frons generally black, sometimes with yellow to cream-coloured bands above and beneath antennal cavity and along ventral margins of eyes (Fig. 10A). Mouthparts dark red brown to black. Maxillary palpi creamcoloured; apical segment black apically (Fig. 10A). Head lateral side black (Fig. 12A). Pronotum generally black, covered with white setae; dorsal disk trapezoidal, posterior margin bisinuated (Fig. 11A). Lateral lobes of pronotum with two variants: (1) in lectotype, completely black except for a cream-coloured oblong spot near anterior margin (Fig. 12A); (2) dorsal third black, otherwise completely yellow. Legs red brown. FIIIs dark red brown, sometimes with a dorsal black longitudinal stripe; knees dark brown to black; TIIIs brown with black spines and spurs, dark brown to black near distal end; tarsomeres dark brown to black. Hindwings hyaline brown, with a rounded transparent window near internal-basal area; longer than FWs, the dark brown tail exceeding FWs more than twice as long as pronotum. Tergites black, in some segments with cream-coloured transverse stripe at anterior end and/or with pale band laterally; sternites pale, their median area red brown. Cerci cream-coloured, short and conical.

\section{Male}

ForEWINGS. FW colouration (Fig. 13A): dorsal field cells mostly transparent to pale yellow, veins mostly dark brown to black. Basal area brown with tint of black. R brown, Sc projections brown basally, transparent apically. Lateral field yellow brown, apex more transparent. FW venation (Fig. 13A): 1A somewhat straight. Harp slightly longer than wide, with 3 oblique veins, posterior-most vein bifurcated at base. $\mathrm{c} 1$ long and wide, $\mathrm{c} 2$ diamond-shaped; mirror (d1) longer than wide, not rounded, generally separated into two parts by a distinct, roundly bent transverse vein, the posterior part hexagonal, shorter than anterior part. Cell $\mathrm{d} 2$ narrower than $\mathrm{d} 1$. Apical field short and rounded, with 2 wide cell alignments 
posterior to mirror and a narrow apical alignment; veins yellow. Lateral field with 5-6 projections of Sc. Epiproct black. Subgenital plate pale cream, its median area and anterior and posterior margins black.

Genitalia (Fig. 16A). Pseudepiphallus sclerotized, relatively large and broad compared to congeners, anterior margin somewhat broad and straight, posterior margin also straight, lateral margins faintly converging posteriorly. Posterior apex with paired lophi longer than wide (at base), subacute at apex, sclerotized laterally only and covered with strong short setae; spaced apart from one another. Rami swollen preapically, anterior apex somewhat truncated. Pseudepiphallic parameres narrow, divergent posteriorly, their basis membranous, with a sclerotized lobe on anterior apex. Ectophallic arc transverse, complete, with anterior and posterior margins straight. Ectophallic fold strong rounded lateral sclerites appearing bean-shaped. Ectophallic apodemes long and thin, straight and slightly divergent basally. Endophallic sclerite large and sclerotized, its posterior apex with divergent lateral arms and with a short median expansion curved dorsally. Endophallic apodeme with lateral lamellae stout.

\section{Female}

FoREWINGS. FW colouration (Fig. 14A): cells on dorsal field mostly infumated black, gradually becoming yellow near $\mathrm{CuA}, \mathrm{M}$ and $\mathrm{R}$ veins; veins generally black or dark brown, also gradually becoming yellow towards $\mathrm{CuA}, \mathrm{M}$ and R veins; veins near apical area also yellow. Sc projections cream-coloured basally, black apically. Lateral field dark. FW venation: 6-7 strong longitudinal veins on dorsal field, sometimes not smooth; lateral field with 6 projections of Sc.
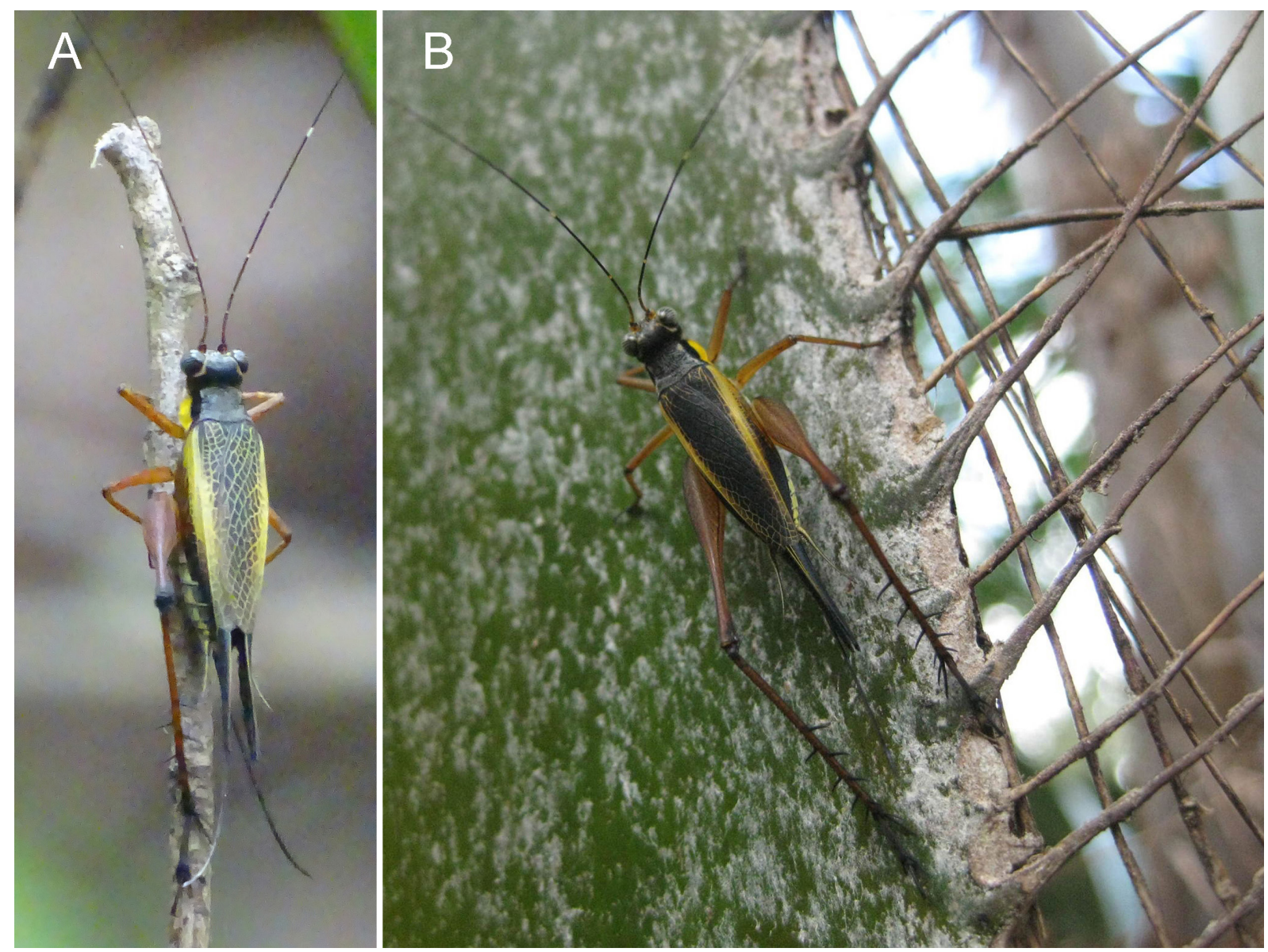

Fig. 18. Nisitrus brunnerianus Saussure, 1878. A. In its natural environment. B. In an oil palm plantation. Photograph source and credits: iNaturalist; James Steamer (A), Ganjar Cahyadi (B). 
Table 3. Measurements of Nisitrus brunnerianus Saussure, 1878 (in mm, means in brackets).

\begin{tabular}{|c|c|c|c|c|c|c|c|c|}
\hline & PronL & PronW & FWL & FWW & HWT & FIIIL & FIIIW & TIIIL \\
\hline Males $(n=4)$ & $\begin{array}{c}2.1-2.3 \\
(2.2)\end{array}$ & $\begin{array}{c}3.6-3.8 \\
(3.7)\end{array}$ & $\begin{array}{c}10.8-11.7 \\
(11.2)\end{array}$ & $\begin{array}{c}4.1-4.8 \\
(4.4)\end{array}$ & $\begin{array}{c}5.1-8.3 \\
(6.8)\end{array}$ & $\begin{array}{c}13.8-14.7 \\
(14.3)\end{array}$ & $\begin{array}{c}2.0-2.6 \\
(2.4)\end{array}$ & $\begin{array}{c}14.3-15.3 \\
(14.8)\end{array}$ \\
\hline \multirow[t]{3}{*}{ Females $(\mathrm{n}=5)$} & $\begin{array}{c}1.9-2.6 \\
(2.2)\end{array}$ & $\begin{array}{c}3.3-3.8 \\
(3.5)\end{array}$ & $\begin{array}{c}11.8-14.6 \\
(13)\end{array}$ & $\begin{array}{c}3.7-4.1 \\
(3.9)\end{array}$ & $\begin{array}{c}7.1-8.4 \\
(7.7)\end{array}$ & $\begin{array}{c}13.8-17.5 \\
(15.9)\end{array}$ & $\begin{array}{c}2.6-3.2 \\
(2.8)\end{array}$ & $\begin{array}{c}12.3-18.7 \\
(15.4)\end{array}$ \\
\hline & & Dorsal s] & ines of TIII & & & & & \\
\hline & Ias & Ibs & Oas & Obs & TaIIIs & \multicolumn{2}{|c|}{ OL } & \\
\hline Males $(n=4)$ & $\begin{array}{c}15-16 \\
(15)\end{array}$ & $2-4$ & $\begin{array}{c}23-26 \\
(25)\end{array}$ & $2-5$ & $2-4$ & \multicolumn{2}{|c|}{-} & \\
\hline Females $(\mathrm{n}=5)$ & $\begin{array}{c}11-15 \\
(14)\end{array}$ & $2-6$ & $\begin{array}{c}19-26 \\
(22)\end{array}$ & $2-5$ & 2 & \multicolumn{2}{|c|}{$\begin{array}{c}14.7-19.9 \\
(17.5)\end{array}$} & \\
\hline
\end{tabular}

GeNITALIA. Ovipositor: on average longer than FIII; apex thin with both dorsal and ventral edges smooth. Copulatory papilla conical, slender, more elongated than congeners; apex folded ventrally, long and slender, pointed; dorsal face with a sclerotized area; ventro-anterior end forming a somewhat triangular $\operatorname{rim}$ (Fig. 17A-B).

\section{Juvenile}

Unknown.

\section{Measurements}

See Table 3.

\section{Ecology}

Unknown.

\section{Distribution}

Borneo (Kalimantan, Sarawak), West Java.

\section{Calling song}

Unknown.

Nisitrus crucius Robillard \& Tan sp. nov. urn:lsid:zoobank.org:act:3140F3A4-21FB-4BB4-ACC6-57BD749A6C3B

Figs 5, 7B, 8C, 10B, 11B, 12B, 13B, 14B, 16B, 17C-D; Tables 2, 4

\section{Diagnosis}

This species differs from all known congeners by the following combination of characters: frons yellow, with a cross-shaped black pattern above mouthparts; face part of fastigium between eyes black. Male FWs with a basal area generally paler; female ovipositor only about as long as FIII. Nisitrus crucius sp. nov. is similar to N. brunnerianus, from which it differs by smaller size and shorter ovipositor. It is also similar in size to $N$. vittatus and $N$. malaya sp. nov. but differs by female FW with cells on dorsal field mostly infumated black, gradually becoming yellow near $\mathrm{CuA}, \mathrm{M}$ and $\mathrm{R}$ veins. 


\section{Etymology}

The species name refers to the dark cross marking on the frons ('crucis' = 'cross', in Latin).

\section{Material examined}

\section{Holotype}

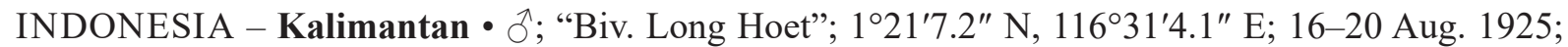
H.C. Siebers leg.; MNHN-EO-ENSIF11261.

\section{Paratypes}

INDONESIA - Kalimantan • 1 q; "Long Navang” [Long Nawang]; Mjöberg leg.; MNHN-EOENSIF11262 • 1 \%; "Midden O. Borneo, Marah"; 058'31" N, 116³3'14.8" E; 10-28 Nov. 1925; H.C. Siebers leg.; MNHN-EO-ENSIF11263 • 1 9; "Biv. Long Hoet"; $1^{\circ} 21^{\prime} 7.2^{\prime \prime}$ N, 116 31'4.1" E; 1620 Aug. 1925; H.C. Siebers leg.; MNHN-EO-ENSIF11264 • 1 q; "Melawi W Borneo"; 0³4'28" S, $111^{\circ} 45^{\prime} 5^{\prime \prime}$ E; Nov.-Dec. 1924; Blanchemanche leg.; MNHN-EO-ENSIF1732 • 1 ô; $^{\top}$ same collection data as for preceding; MNHN-EO-ENSIF11265 • 1 क; "Samarinda"; 0²9'47" S, 117²'23" E; M.-E. Walsh leg.; ZMLU.

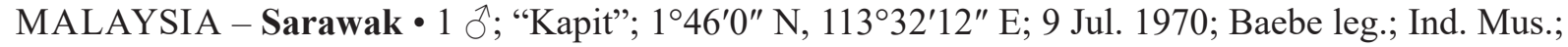

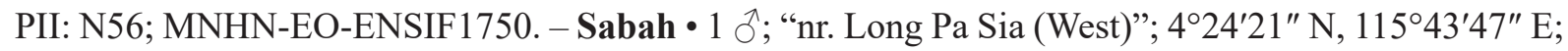
“c. 1200m”; 2-13 Apr. 1987; C. v. Achterberg leg.; RMNH.

NO COUNTRY • 1 क; "Borneo”; 1891; Chaper leg.; MNHN-EO-ENSIF11266.

\section{Description}

Average size (Fig. 7B). Colour pattern somewhat intermediate between N. brunnerianus and N. vittatus. Vertex black with cream-coloured margin around eyes (Fig. 11B). Fastigium velvety black with creamcoloured margins. Scapes black dorsally, sometimes reddish ventrally or along dorso-inner margins. Antennae black. Frons yellow, face part of fastigium black between eyes, with a cross-shaped black pattern above mouthparts; clypeus sometimes darkened, mouthparts dark red brown to black (Fig. 10B). Maxillary palpi cream-coloured. Head lateral side generally black. Pronotal disk black with white setae (Fig. 11B). Lateral lobes of pronotum with dorsal third black, cream-coloured ventrally (Fig. 12B). Legs red brown, sometimes internal-basal area black. FIIIs dark red brown, knees dark brown to black; TIIIs brown with black spines and spurs, dark brown to black near distal end; tarsomeres dark brown to black. Hindwings dark hyaline, with a rounded transparent window near internal-basal area; longer than FWs, the dark brown tail exceeding the FWs about twice as long as pronotum. Tergites black, with a pale band laterally of variable thickness; sternites pale, with a black median area.

\section{Male}

Forewings. FW colouration (Fig. 13B): dorsal field cells mostly transparent; veins mostly creamcoloured, sometimes black. Basal area brown, basally cream-coloured, brown towards distal part. R and Sc projections cream-coloured. Lateral field hyaline, with dorsal parts infumated cream-coloured. FW venation (Fig. 13B): 1A somewhat straight. Harp slightly longer than wide, with 2 oblique veins, distal one bifurcate basally. Cell $\mathrm{c} 1$ long and wide, $\mathrm{c} 2$ diamond-shaped; mirror (d1) longer than wide, not rounded, generally separated into two parts by a distinct straight transverse vein, the posterior part somewhat rectangular, much shorter than anterior part. Cell $\mathrm{d} 2$ narrower than $\mathrm{d} 1$, usually subdivided by accessory veins. Apical field short and rounded, with 3 wide cell alignments posterior to mirror and a narrow apical alignment; veins cream-coloured. Lateral field with 5 projections of Sc. Epiproct black. Subgenital plate pale cream-coloured with median area and anterior and posterior margins black. 
Table 4. Measurements of Nisitrus crucius Robillard \& Tan sp. nov. (in mm, means in brackets).

\begin{tabular}{|c|c|c|c|c|c|c|c|c|}
\hline & PronL & PronW & FWL & FWW & HWT & FIIIL & FIIIW & TIIIL \\
\hline Male holotype & 2.1 & 2.9 & 10.8 & 3.7 & 6.9 & 13.0 & 2.3 & 12.0 \\
\hline Males $(n=3)$ & $\begin{array}{c}1.7-2.1 \\
(1.9)\end{array}$ & $\begin{array}{c}2.9-3.4 \\
(3.1)\end{array}$ & $\begin{array}{c}9.9-10.8 \\
(10.3)\end{array}$ & $\begin{array}{c}3.7-4.2 \\
(4.0)\end{array}$ & $\begin{array}{c}5.3-7.0 \\
(6.4)\end{array}$ & $\begin{array}{c}12.5-13.0 \\
(12.7)\end{array}$ & $\begin{array}{c}2.3-2.8 \\
(2.5)\end{array}$ & $\begin{array}{c}12.0-13.0 \\
(12.5)\end{array}$ \\
\hline \multirow[t]{3}{*}{ Females $(\mathrm{n}=5)$} & $\begin{array}{l}1.9-2.1 \\
(2.0)\end{array}$ & $\begin{array}{c}2.8-3.5 \\
(3.3)\end{array}$ & $\begin{array}{c}10.5-11.7 \\
(11.3)\end{array}$ & $\begin{array}{c}3.0-3.3 \\
(3.2)\end{array}$ & $\begin{array}{c}6.5-8.0 \\
(7.1)\end{array}$ & $\begin{array}{c}13.1-14.5 \\
(13.9)\end{array}$ & $\begin{array}{c}2.6-2.9 \\
(2.7)\end{array}$ & $\begin{array}{c}13.0-15.0 \\
(14.1)\end{array}$ \\
\hline & \multicolumn{4}{|c|}{ Dorsal spines of TIII } & & \multirow{2}{*}{\multicolumn{2}{|c|}{ OL }} & \\
\hline & Ias & Ibs & Oas & Obs & TaIIIs & & & \\
\hline Male holotype & 16 & $3-5$ & 23 & $3-5$ & 4 & \multicolumn{2}{|c|}{-} & \\
\hline Males $(n=3)$ & $\begin{array}{c}13-16 \\
(15)\end{array}$ & $3-5$ & $\begin{array}{c}17-23 \\
(20)\end{array}$ & $3-7$ & 4 & \multicolumn{2}{|c|}{-} & \\
\hline Females $(\mathrm{n}=5)$ & $\begin{array}{c}11-12 \\
(12)\end{array}$ & $3-4$ & $\begin{array}{c}19-20 \\
(20)\end{array}$ & $3-8$ & $3-4$ & \multicolumn{2}{|c|}{$\begin{array}{c}13.8-15.0 \\
(14.3)\end{array}$} & \\
\hline
\end{tabular}

Genitalia (Fig. 16B). Pseudepiphallus sclerotized, stout (small but broad) compared to congeners, anterior margin somewhat broad and straight, posterior margin also straight, lateral margins faintly converging posteriorly. Posterior apex with paired lophi slightly longer than wide (at base), obtuse at apex, sclerotized laterally only and covered with short strong setae; narrowly spaced apart from one another. Rami swollen preapically, anterior apex somewhat truncated. Pseudepiphallic parameres narrow, divergent posteriorly, their basis membranous, with a sclerotized lobe on anterior apex. Ectophallic arc transverse, complete, with anterior and posterior margins straight. Ectophallic fold strong rounded lateral sclerites appearing bean-shaped. Ectophallic apodemes long, straight and slightly divergent basally. Endophallic sclerite large and sclerotized, its posterior apex with divergent lateral arms and with a short median expansion curved dorsally. Endophallic apodeme with lateral lamellae stout.

\section{Female}

ForEWINGS. FW with cells on dorsal field mostly infumated black, gradually becoming yellow near $\mathrm{CuA}, \mathrm{M}$ and R veins; veins generally yellow (Fig. 14B). Sc projections cream-coloured. Lateral field transparent, sometimes infumated black apically.

GeNITALIA. Ovipositor: only slightly longer than FIII. Copulatory papilla conical, smaller and stout; apex folded ventrally, short, pointed; dorsal face with a sclerotized area; ventro-anterior end forming an oval to pyriform rim (Fig. 17C-D).

\section{Juvenile}

Unknown.

\section{Measurements}

See Table 4.

\section{Ecology}

Unknown.

\section{Distribution}

Borneo (Kalimantan, Sabah, Sarawak). 


\title{
Type locality
}

Indonesia, Kalimantan.

\section{Calling song}

Unknown.

\author{
Nisitrus danum Robillard \& Tan sp. nov. \\ urn:Isid:zoobank.org:act:0DEB5BDB-6E85-4691-B5D1-E6258239370A
}

Figs 5, 8D, 10C, 11C, 12C, 14C, 17E, 19; Tables 2, 5

\section{Diagnosis}

This new species differs from all known congeners by face part of fastigium with a black band across eyes and antennal cavity, frons otherwise yellow (reddish on preserved specimens); pronotal lateral lobe black dorsally and yellow ventrally; longitudinal white stripe only between $\mathrm{M}$ and $\mathrm{R}$ and lateral field matted black; Sc projections black. This new species is most similar to $N$. hughtani sp. nov. from Sumatra, but differs by the following characters: smaller in size, vertex black with yellow margin around eyes (instead of cream-coloured), frons with a black band across eyes and antennal cavity (yellow in N. hughtani sp. nov.); frons yellow (instead of black with a cream-coloured band ventral to eyes); mouthparts yellowish with some black spots; lateral part of head with a black band posterior of eye (instead of black with a cream-coloured ring around eye). This species is also similar to N. musicus from Kinabalu range, but differs by mouthparts yellow (instead of black), FIIIs not black dorsally, female papilla, and distribution: $N$. musicus is restricted to the highlands in the Kinabalu range, while $N$. danum sp. nov. occurs in the Danum Valley and Tawau Hill areas at the east of Sabah.

\section{Etymology}

The specific name is a noun in apposition taken from the type locality, Danum Valley, Malaysia.

\section{Material examined}

\section{Holotype}

MALAYSIA - Sabah • + ; Danum Valley Field Centre; 4 57'52.95" N, $117^{\circ} 48^{\prime} 18.25^{\prime \prime}$ E; ca 150 m a.s.l.; 26 May-20 Jun. 1987; C. v. Achterberg and Kennedy leg.; PII: N54; RMNH.

\section{Paratypes}

MALAYSIA - Sabah • 1 q; same collection data as for holotype; RMNH • 1 q; same collection data as for holotype; MNHN-EO-ENSIF10945.

\section{Additional specimens}

MALAYSIA - Sabah • 1 क; Tawau Hill Park; 4²4'0.0" N, 11753'24.0" E; 7 Mar. 2018; C. Elder leg.; iNaturalist.org/observations/19511712 • 1 क ; Danum Valley; 457'42.6" N, 117²41'22.2" E; 2 Oct. 2020; L. Day leg.; iNaturalist.org/observations/21010925.

\section{Description}

Slender and relatively large habitus (Figs 8D, 19). Vertex black with yellow margin around eyes (Fig. 11C). Fastigium velvety black with yellow margins. Scapes dark red brown to black (particularly on the dorsoinner margins). Antennae black with wide whitish rings. Face part of fastigium with a black band across eyes and antennal cavity, otherwise yellow (reddish in preserved specimens); frons almost entirely yellow, including mouthparts, with some black spots (Fig. 10C). Maxillary palpi cream-coloured; apical segment black apically (Fig. 10C). Lateral part of head with a black band posterior to eye (Fig. 12C). Pronotum 
covered with white setae; dorsal disk dark brown to black (Fig. 11C). Lateral lobes of pronotum dorsal third black, vivid yellow ventrally (cream-coloured in preserved specimens) (Fig. 12C). Legs generally red brown, sometimes dorsally darker. FIIIs brown, knees dark brown to black; TIIIs brown with black spines and spurs, dark brown to black near distal end; tarsomeres dark brown to black. Tergites red brown, with a pale band laterally; sternites pale, with red brown median area. Cerci red brown, short and conical.

Male

Unknown.
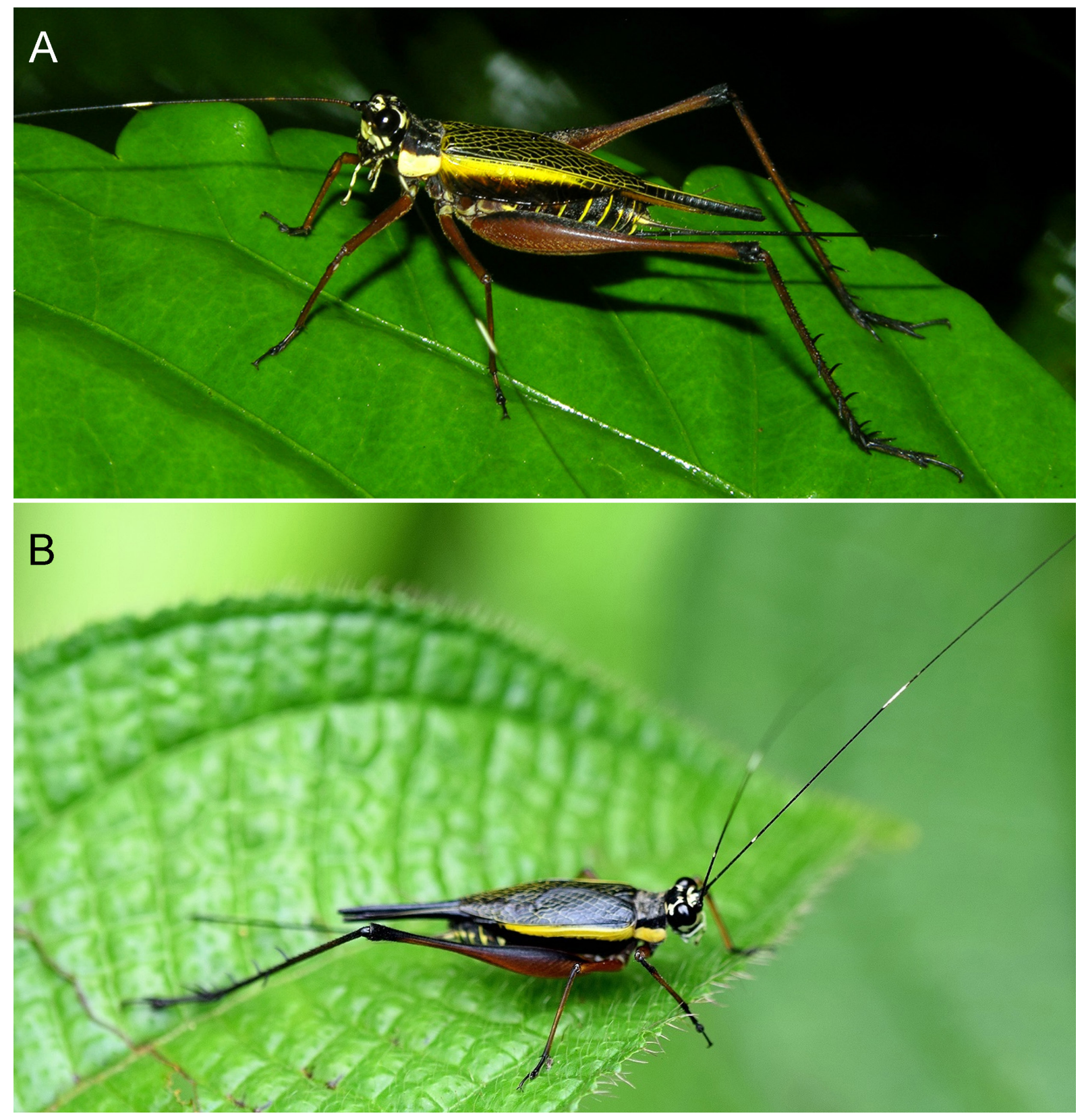

Fig. 19. Nisitrus danum Robillard \& Tan sp. nov., adult $q+$ in their natural environment. Photograph source and credits: iNaturalist; Arthur Anker (A), Charlie Elder (B). 
TAN M.K. et al., Revision of Nisitrus (Orthoptera: Eneopterinae)

Table 5. Measurements of Nisitrus danum Robillard \& Tan sp. nov. (in mm, means in brackets).

\begin{tabular}{lcccccccc}
\hline & PronL & PronW & FWL & FWW & HWT & FIIIL & FIIIW & TIIIL \\
\hline Female holotype & 2.0 & 3.2 & 10.8 & 3.5 & 6.4 & 15.3 & 2.7 & 15.5 \\
Females (n=3) & $2.0-2.3$ & $3.2-3.5$ & $10.8-11.7$ & $3.5-4.2$ & $6.4-7.7$ & 15.3 & 2.7 & 15.5 \\
& $(2.2)$ & $(3.4)$ & $(11.4)$ & $(4.0)$ & $(7.2)$ & $(15.3)$ & $(2.7)$ & $(15.5)$ \\
\cline { 2 - 5 } & Ias & Ibs & Oas & Obs & TaIIIs & OL & \\
\cline { 2 - 6 } & 13 & $2-3$ & 24 & $2-3$ & 2 & 17.2 & \\
Female holotype & NA & NA & NA & NA & NA & $17.2-18.5$ & \\
Females (n=3) & & & & & & $(17.9)$ & \\
& & & & & &
\end{tabular}

\section{Female}

ForEWINGS. FW colouration (Fig. 14C): veins generally yellow; cells infumated black. Longitudinal infumated white stripe only in M and R. Lateral field matted black, Sc projections black. FW venation: 6-7 strong longitudinal veins on dorsal field, cross-veins irregular and often sinuous; lateral field with 6 projections of Sc.

Genitalia. Ovipositor: distinctly longer than FIII; apex thin with both dorsal and ventral edges smooth. Copulatory papilla conical, smaller and stout; apex strongly folded (could be due to the preservation of specimen) ventrally, short, pointed; dorsal face with a sclerotized area (Fig. 17E).

\section{Juvenile}

Unknown.

\section{Measurements}

See Table 5.

\section{Ecology}

Unknown.

\section{Distribution}

Borneo (Sabah).

\section{Type locality}

Malaysia: Sabah.

\section{Calling song}

Unknown.

Nisitrus hughtani Robillard \& Tan sp. nov. urn:lsid:zoobank.org:act:8E5BC124-4F3C-432E-BB94-A19C32128B06

Figs $5,7 \mathrm{C}, 8 \mathrm{E}, 10 \mathrm{D}, 11 \mathrm{D}, 12 \mathrm{D}, 13 \mathrm{C}, 14 \mathrm{D}, 15 \mathrm{~A}, 16 \mathrm{C}, 17 \mathrm{~F}-\mathrm{G}, 20$; Tables 1-2, 6

\section{Diagnosis}

Large and slender species. Head mostly black, but with cream-coloured margin around eyes in both dorsal and lateral views; frons mostly black, but yellow ventral to eyes and antennal cavity; maxillary palpi white. Pronotum dorsal lobe black, lateral lobe mostly white or yellow, its dorsal margin black. Female 
FWs with dorsal field infumated black; lateral field ventrally black; M/R area forming a clearly defined white/yellow stripe. This species is most similar to $N$. danum sp. nov. from Borneo, but differs by the following characters: larger in size, vertex black with cream-coloured margin around eyes (instead of yellow); frons and mouthparts dark red brown to black; frons black with a cream-coloured band ventral to eyes (instead of completely yellow). This species also differs from the sympatric $N$. insignis by frons mostly black (instead of yellow); lateral field M/R area forming a clearly defined white stripe (instead of dark); female FW dorsal field with veins black (instead of yellow) and juvenile colouration.

\section{Etymology}

The new species is named after Prof. Hugh Tiang Wah Tan, a renowned botanist and conservation biologist from Singapore and the PhD supervisor of M.K. Tan.

\section{Material examined}

\section{Holotype}

INDONESIA - Sumatra • +; "Nambaru, Kec. Bundar Pasir Mandage, Kab. Asahan"; 244'24.17" N, 99¹5'02.52" E; 980 m a.s.1.; 5 Aug. 1983; Yusup leg.; MZB.ORTH.12193.

\section{Paratypes}

INDONESIA - Sumatra • 1 \%; same collection data as for holotype; (MZB.ORTH.12192); MNHNEO-ENSIF10946 • 1 क; "Sarapai"; "8 July" 1916; Edward Jacobson leg.; RMNH • 1 ð’; 20 km east of Sasak, environment of Harau Valley National Park; 004'51.79" S, 100³9'08.13" E; 24-26 Nov. 1999; A.V. Gorochov leg.; PIII: N34 Nmb1; ZIN • 1 क; Deli; 3¹9' N, 98 $35^{\prime}$ E; 12 Oct. 1895; W. Burchard

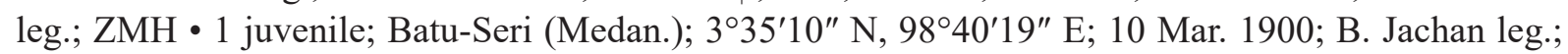
$\mathrm{ZMH} \bullet 1$ juvenile; $20 \mathrm{~km}$ east of Sasak, environment of Harau Valley National Park; 0 04'51.79" S, 100³9'08.13" E; 24-26 Nov. 1999; A.V. Gorochov leg.; ZIN • 1 q; 1877-1878; RMNH.

\section{Additional specimens}

INDONESIA - Sumatra - 1 juvenile; Panti, Pasaman Regency, West Sumatra; 0²0'45.7" N, $100^{\circ} 3^{\prime} 56.4^{\prime \prime}$ E; 25 Jan. 2019; S.B. Shakya leg.; iNaturalist.org/observations/20129372 • 1 o ; Sungai Penuh City, Jambi; $2^{\circ} 05^{\prime} 58.5^{\prime \prime}$ S, 101 ${ }^{\circ} 15^{\prime} 57.8^{\prime \prime}$ E; 18 Jun. 2019; S. Wollney leg.; iNaturalist.org/observations/27481224 • 1 क; Lempur Tengah, Gunung Raya, Kerinci Regency, Jambi; $2^{\circ} 19^{\prime} 24.2^{\prime \prime}$ S, 101³2'11.1" E; 12 Nov. 2019; T. Sanders leg.; iNaturalist.org/observations/36674976 - 1 juvenile; Kerinci, Jambi; $2^{\circ} 15^{\prime} 12.6^{\prime \prime}$ S, 101 ${ }^{\circ} 34^{\prime} 17.0^{\prime \prime}$ E; 12 Aug. 2019; pmaaskant leg.; iNaturalist.org/observations/37984028 • 1 juvenile; Aceh; 3³6'47.6" N, 97²6'23.8" E; 14 Apr. 2009; G. Bohne leg.; iNaturalist.org/observations/27198231 • 1 juvenile; Aceh; 3³6'55.2" N, 97³4'33.3" E; 14 Apr. 2009; G. Bohne leg.; iNaturalist.org/observations/27198588 • 1 juvenile; Aceh; 346'11.5" N, 97³1'57.7" E; 14 Apr. 2009; G. Bohne leg.; iNaturalist.org/observations/27198509 • 1 क; Aceh, Gunung Leuser National Park, Gurah; 346'15" N, 97¹4'25.9" E; 16 Feb. 2014; Michael Kesl leg.; https://www.biolib.cz/en/image/id334434/ • 1 市; Aceh, Gunung Leuser National Park, Gurah; 346 $15^{\prime \prime}$ N, 97¹4'25.9" E; 16 Feb. 2014; Michael Kesl leg.; https://www.biolib.cz/en/image/id334435/・1 juvenile; Aceh, Gunung Leuser National Park, Gurah; 346'15" N, 97¹4'25.9" E; 16 Feb. 2014; M. Kesl leg.; https:/www.biolib.cz/en/image/id334438/ • 2 juveniles; Aceh, Gunung Leuser National Park, Gurah; 346'15" N, 97¹4'25.9" E; 16 Feb. 2014; M. Kesl leg.; https://www.biolib.cz/en/image/id334439/• 1 q; West Sumatra, Gunung Talakmau camp 1; 005'50.1" N, 9956'50.8" E; 15 Mar. 2018; O. Johnson leg.; https://www.inaturalist.org/observations/11085385.

\section{Description}

Habitus large and slender, colouration very contrasting with black, white and vivid yellow when alive (Figs 7C, 20A-B). Vertex black with cream-coloured margin around eyes (Fig. 11D). Fastigium velvety 

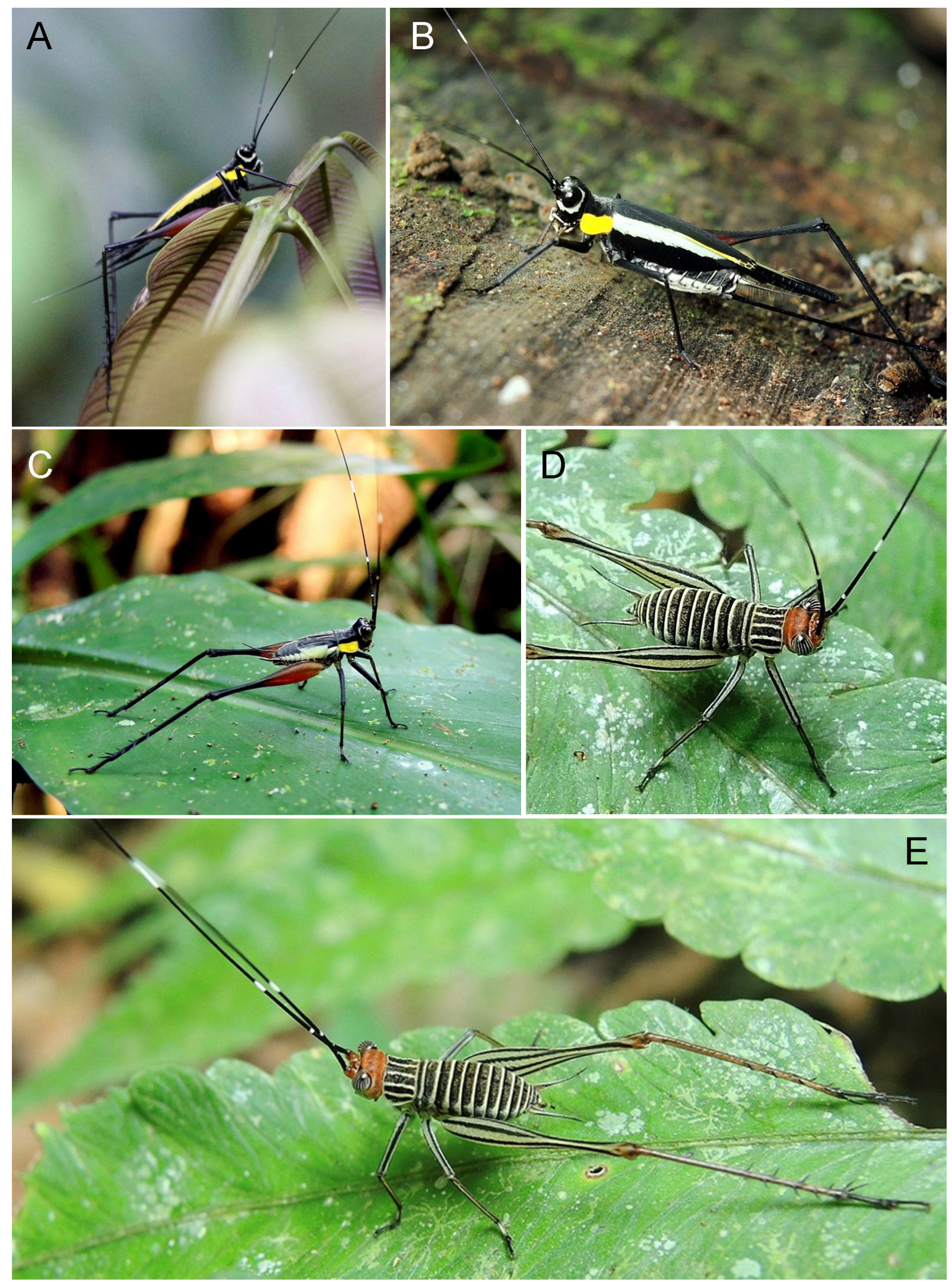

Fig. 20. Nisitrus hughtani Robillard \& Tan sp. nov. in its natural environment in West Sumatra. A-B. Adult 우으. C-E. Juveniles. Photograph source and credits: iNaturalist; Oscar Johnson (A), Michael Kesl (B-E). 
black with cream-coloured margins. Scapes dark red brown to black (particularly on the dorso-inner margins). Antennae black with wide white rings. Frons and mouthparts dark red brown to black, frons cream-coloured (whitish when alive) ventral to eyes (Fig. 10D). Maxillary palpi cream-coloured; apical segment black apically (Fig. 10D). Head lateral side dark coloured, with broad cream-coloured band around eyes extending to area behind eyes (Fig. 12D). Pronotum covered with white setae; dorsal disk velvety black (Fig. 11D). Lateral lobes of pronotum with dorsal-third black, cream-coloured ventrally, vivid yellow when alive (Fig. 12D). Legs dark brown. FIII brown, knees dark brown to black; TIIIs brown with black spines and spurs, dark brown to black near distal end; tarsomeres dark brown to black. Hindwings hyaline brown apically, longer than FWs, the dark brown tail exceeding FW more than twice as long as pronotum. Tergites red brown, with a pale band laterally; sternites pale, with a red brown median area. Cerci red brown.

\section{Male}

ForEWINGS. FW colouration (Fig. 13C): dorsal field cells mostly transparent, veins mostly dark brown to black, cream-coloured in apical field. Basal area brown, basally cream-coloured, brown towards distal part. R cream-coloured, Sc projections cream-coloured basally, black apically. Lateral field brown. FW venation (Fig. 13C): 1A curved, slightly angulated. Harp slightly longer than wide, with 3 oblique veins, basal one bifurcate distally, distal one bifurcate basally. c1 long and wide, c2 diamond-shaped; mirror (d1) longer than wide, not rounded, generally separated into two parts by a distinct transverse vein, the posterior part hexagonal, shorter than anterior part. Cell $\mathrm{d} 2$ narrower than $\mathrm{d} 1$, more or less rectangular. Apical field short and rounded, with 3 wide cell alignments posterior to mirror and a narrow apical alignment. Lateral field with 6 projections of Sc. Epiproct black. Subgenital plate pale cream-coloured with median area, anterior and posterior margins black.

Genitalia (Fig. 16C). Pseudepiphallus sclerotized, large and slender, anterior margin narrow and straight, posterior margin also straight, lateral margins distinctly converging posteriorly. Posterior apex with paired lophi longer than wide (at base), subacute at apex, sclerotized laterally only and covered with short strong setae, narrowly spaced apart from each other. Rami swollen preapically, somewhat sinuous. Pseudepiphallic parameres narrow, divergent posteriorly sclerotized arm base to parameres distinctly curved laterally. Ectophallic arc transverse, complete, with anterior and posterior margins straight. Ectophallic fold strong rounded lateral sclerites appearing bean-shaped. Ectophallic apodemes long, straight and slightly divergent. Endophallic sclerite large and sclerotized, its posterior apex with divergent lateral arms and with a short median expansion curved dorsally. Endophallic apodeme with lateral lamellae and dorsal crest only slightly longer than wide.

\section{Female}

ForEWINGS. FW colouration (Fig. 14D): cells black, veins generally black. Longitudinal white stripe around region of $\mathrm{CuA}, \mathrm{M}$ and $\mathrm{R}$ with a distinct margin against black colouration on dorsal field; Sc projections cream-coloured basally, black apically. Lateral field dark. FW venation: 6-7 strong longitudinal veins on dorsal field; lateral field with 6 projections of Sc.

Genitalia. Ovipositor: distinctly longer than FIII. Copulatory papilla conical, large (similar to $N$. brunnerianus but less slender-possibly due to preservation of specimen); apex folded ventrally, elongated like in $N$. brunnerianus, pointed; dorsal face with a sclerotized area, but less sclerotized than in congeners; ventro-anterior end forming a somewhat triangular rim (Fig. 17F-G).

Juvenile (Fig. 20C-E)

Early instars with a pale colouration with numerous dark stripes all around body. Head generally reddish. Eyes with numerous dark stripes. Pronotum with three thick, dark longitudinal stripes on dorsal disk, one very thick and velvety black stripe between dorsal disk and lateral lobe; another curved stripe on lateral 
TAN M.K. et al., Revision of Nisitrus (Orthoptera: Eneopterinae)

Table 6. Measurements of Nisitrus hughtani Robillard \& Tan sp. nov. (in mm, means in brackets).

\begin{tabular}{|c|c|c|c|c|c|c|c|c|}
\hline & PronL & PronW & FWL & FWW & HWT & FIIIL & FIIIW & TIIIL \\
\hline Female holotype & 2.5 & 4.0 & 14.8 & 4.9 & 8.4 & 16.5 & 2.7 & 16.2 \\
\hline Females $(\mathrm{n}=5)$ & $\begin{array}{c}2.2-2.6 \\
(2.4)\end{array}$ & $\begin{array}{c}3.7-4.0 \\
(3.8)\end{array}$ & $\begin{array}{c}12.5-14.8 \\
(13.6)\end{array}$ & $\begin{array}{c}4.4-4.9 \\
(4.7)\end{array}$ & $\begin{array}{c}8.3-8.7 \\
(8.4)\end{array}$ & $\begin{array}{c}16.5-17.2 \\
(16.8)\end{array}$ & $\begin{array}{c}2.7-3.2 \\
(2.9)\end{array}$ & $\begin{array}{c}16.2-18.0 \\
(17.1)\end{array}$ \\
\hline \multirow[t]{3}{*}{ Male $(\mathrm{n}=1)$} & 2.2 & 3.4 & 10.6 & $?$ & 8.0 & 13.9 & 2.3 & 14.6 \\
\hline & \multicolumn{4}{|c|}{ Dorsal spines of TIII } & & \multirow{2}{*}{\multicolumn{2}{|c|}{ OL }} & \\
\hline & Ias & Ibs & Oas & Obs & TaIIIs & & & \\
\hline Female holotype & 15 & $2-3$ & 22 & $2-3$ & 3 & \multicolumn{2}{|c|}{19.5} & \\
\hline Females $(\mathrm{n}=3)$ & $\begin{array}{c}15-16 \\
(15)\end{array}$ & $2-3$ & $\begin{array}{c}21-24 \\
(22)\end{array}$ & $2-3$ & $2-3$ & \multicolumn{2}{|c|}{$\begin{array}{c}18.6-21.4 \\
(19.5)\end{array}$} & \\
\hline Male $(\mathrm{n}=1)$ & 14 & $2-3$ & 20 & $2-3$ & 2 & \multicolumn{2}{|c|}{ - } & \\
\hline
\end{tabular}

lobe ventral of the thick stripe; stripes never reaching the margins. Fore and middle legs with longitudinal dark stripes. FIII also with longitudinal dark stripes, two dorsally, one on each side; and two ventrally, one on each side. Thoracic (excluding pronotum) and abdominal tergites typically dark or greyish, anterior margin darkest, posterior margin whitish. Cerci whitish with a black stripe.

\section{Measurements}

See Table 6

\section{Ecology}

Unknown.

\section{Distribution}

Northern Sumatra.

\section{Type locality}

Indonesia, northern Sumatra.

\section{Calling song}

Unknown.

\section{Nisitrus hyalinus Saussure, 1878}

Fig. 21; Table 2

Nisitrus hyalinus Saussure, 1878: 516.

Nisitrus hyalinus - Chopard 1968: 353. - Hollier et al. 2013: 487 (no types in MHNG). - Cigliano et al. 2020 (Orthoptera Species File online).

Nisitra hyalina - Kirby 1906: 87. — Chopard 1969: 313.

non Nisitrus hyalinus - Chopard 1929: 110 (record in Siberut may be N. insignis). — Robillard \& Desutter-Grandcolas 2004a: 276 (morphological phylogeny). 


\section{Type locality}

Borneo: Kalimantan, "Benjermassing” [Banjarmasin].

\section{Type details}

Syntypes, RMNH (missing).

\section{Remarks}

The syntypes in RMNH are missing. L. Chopard's records (Chopard 1929) of this species in Mentawai, North Pagi, Siberut and Padang (all part of or related to Sumatra, Indonesia) correspond to specimens of $N$. insignis, while $N$. hyalinus is known only from Borneo. We cannot revise this species owing to the absence of type material and of other specimens from the region of the type locality in the south of Borneo. Nonetheless, we have found images of specimens from Sungai Utik, Embaloh Hulu, Kapuas Hulu Regency, West Kalimantan, albeit not exactly near the type locality in Banjarmasin in South Kalimantan, which could possibly correspond to $N$. hyalinus. These photographs (Fig. 21) match the description by Saussure (1878): "Les élytres latéralement hyalins dans leur partie marginale, d'un noir opaque luisant dans leur partie médiastino-humérale; le champ dorsal brunâtre, réticulé en jaune par mailles plus grandes que chez le N. vittatus. Ailes assez courtes, hyalines, nébuleuses, surtout le long du limbe. Fémurs postérieurs très longs; leur moitié apicale linéaire, comme chez le N. insignis". [The elytra laterally hyaline in their marginal part, a shiny opaque black in their medial-humeral part; the dorsal field brownish, reticulated in yellow with larger meshes than in N. vittatus. Wings rather short, hyaline, nebulous, especially along the limbus. Very long FIII; their apical half linear, as in N. insignis.]

We can also confirm that none of the Bornean specimens examined in this study match the description of $N$. hyalinus. Saussure (1878) repeatedly compared $N$. hyalinus with $N$. vittatus, but not with other Bornean species which differ distinctly from $N$. vittatus (i.e., N. brunnerianus). Nisitrus danum sp. nov. differs
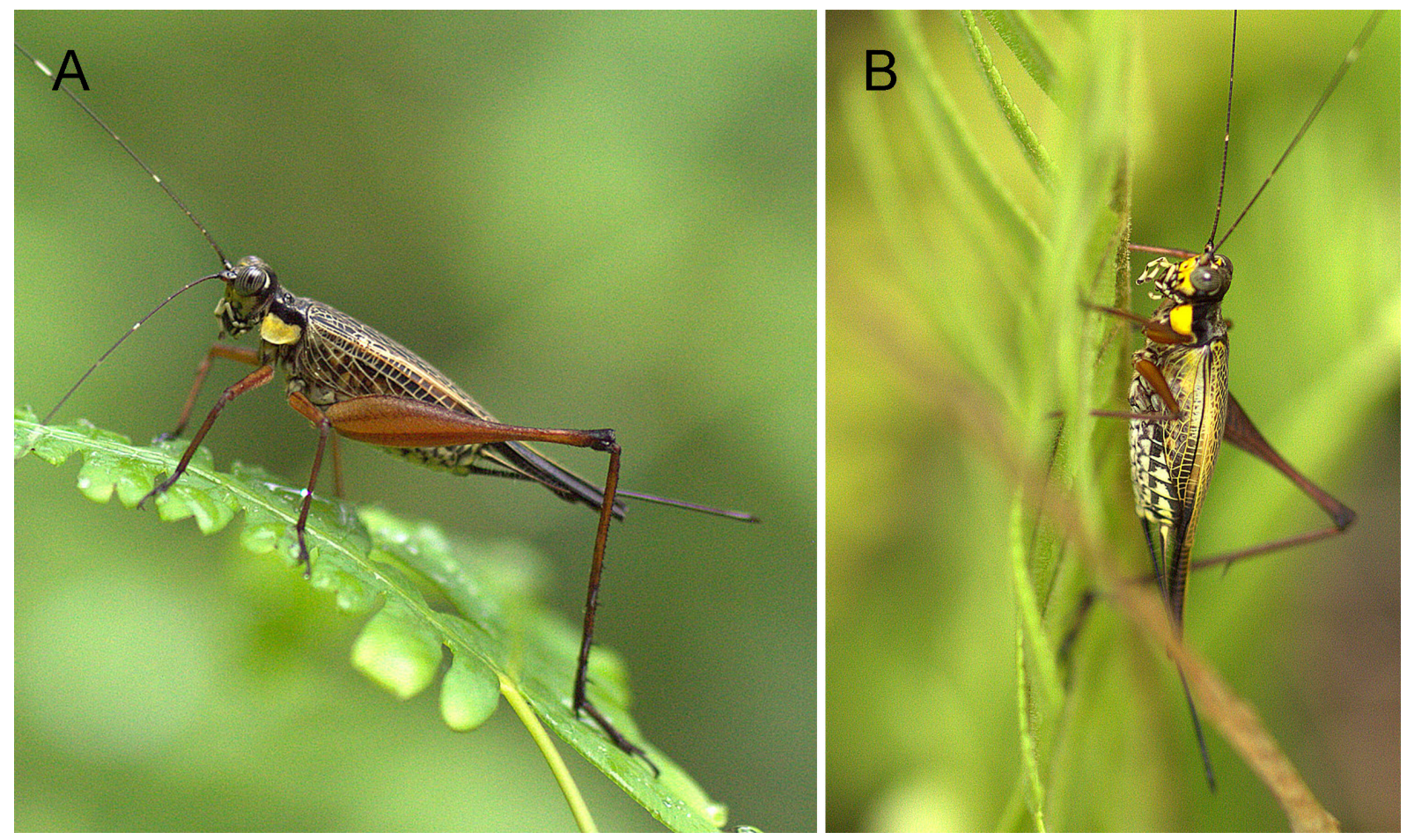

Fig. 21. Nisitrus hyalinus?, adult $q \circ$ in their natural environment. Photograph source and credits: Marcel Silvius. 
from $N$. hyalinus by dorsal field clearly not brownish; lateral field humeral stripe whitish, not shining black; lateral field is not hyaline either. Furthermore, the type locality of $N$. hyalinus from Banjarmasin in southern Kalimantan is quite far from Danum Valley and of a different forest type (Danum Valley is lowland forest, whereas Banjarmasin would have been peat swamp forest). Nisitrus rindu sp. nov. also differs by medial-humeral part not shining black opaque. Given the fact that very few specimens of Nisitrus are known from Southern Borneo, it is likely that $N$. hyalinus is a valid species but rarely collected.

Nisitrus insignis Saussure, 1878

Figs 2A, 5, 7D, 8F, 10E, 11E, 12E, 13D, 14E, 16D, 17H-I, 22; Tables 1-2, 7

Nisitrus insignis Saussure, 1878: 515.

Crystallomorpha sumatrensis Rehn, 1909: 209. Syn. nov.

Nisitra insignis - Kirby 1906: 87. - Chopard 1968: 352.

Nisitrus insignis - Chopard 1968: 352. — Vicente et al. 2017: 2203 (molecular phylogeny). — Hollier et al. 2013: 487 (no types in MHNG). — Cigliano et al. 2020 (Orthoptera Species File online).

Nisitrus sumatrensis - Robillard \& Desutter-Grandcolas 2004a: 276 (morphological phylogeny).

Nisitrus hyalinus - Chopard 1929: 110. — Robillard \& Desutter-Grandcolas 2004a: 276 (morphological phylogeny).

Nisitrus sp. - Preston-Mahfam 2000: 1 (mating behaviour).

\section{Diagnosis}

Of smaller size but stouter habitus than congeners. Vertex coloration ranging from black with creamcoloured margins around eyes and fastigium to cream-coloured with a strong longitudinal black band and one or two faint transverse black band (forming a T- or a cross-shaped black pattern). FIIIs brown, with a brown longitudinal stripe along external ventral half; sometimes dorsal margin with a paler longitudinal stripe. Dorsal field of male FW always with cream-coloured triangular (sometimes rounded) patch, with very distinctly different venation; harp very small, slightly longer than wide, with one distinct straight oblique vein. This species is similar to $N$. malaya sp. nov. and N. vittatus but differs by legs with lighter colouration and dorsum of head yellow with variable black pattern (instead of entirely black). This species also differs from the sympatric $N$. hughtani sp. nov. by smaller size, frons yellow (black in $N$. hughtani sp. nov.) and vertex colouration pattern; FW lateral field M/R area dark (instead of forming a clearly defined white/yellow stripe), and female FW dorsal field with veins yellow (instead of mostly black).

\section{Material examined}

Lectotype (here designated)

INDONESIA - Sumatra • O; "Neit Suma" [North Sumatra]; 1853; Mus. Caes. Vindobon; NMW.

\section{Additional specimens}

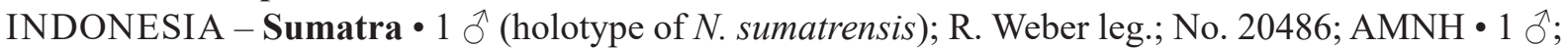
"Mentawei" [Siberut] "Siberoet"; 1²3'17.3" S, 98 56'7.7" E; 22 Sep. 1924; H.H. Karny leg.; MNHN •

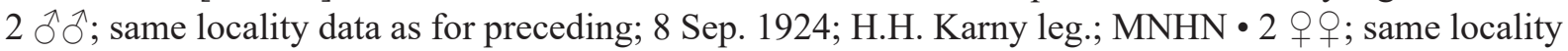
data as for preceding; 8 Sep. 1924; H.H. Karny leg.; identified as Nisitra hyalina by L. Chopard; MNHN - 3 o $\circ$; same locality data as for preceding; 12 Sep. 1924; H.H. Karny leg.; MNHN • 3 q ; same

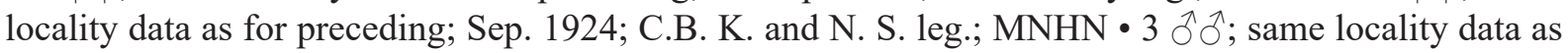
for preceding; Sep. 1924; C.B. K. and N. S. leg.; MNHN; • 1 J ; "Mentawei" Sipora Island; $2^{\circ} 13^{\prime 2} 28.7^{\prime \prime}$ S, 99 40'9.4" E; Oct. 1924; C.B. K. and N. S. leg.; identifed Nisitrus brunnerianus by T. Robillard, 2004; MNHN-EO-ENSIF 1748 • 1 क ; same collection data as for preceding; MNHN • 1 \&; "Mentawei" [Siberut] 


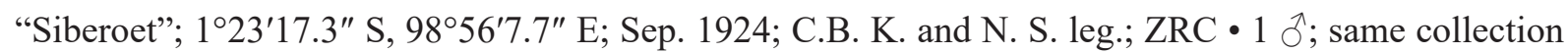
data as for preceding; PII: N55; ZRC • 2 o 9 ; Sibolangit; $3^{\circ} 18^{\prime} 2^{\prime \prime}$ N, 98 $8^{\circ} 34^{\prime} 8^{\prime \prime}$ E; Sep.-Oct. 1929;

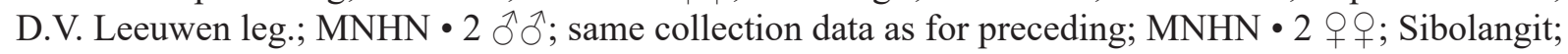
$3^{\circ} 18^{\prime} 2^{\prime \prime}$ N, 98 $8^{\circ} 34^{\prime} 8^{\prime \prime}$ E; 8 Oct. 1925; Fulmek and H. Karny leg.; 2 q 9 ; 20 km east of Sasak environs of Harau Valley National Park; 04'57" S, 100³9'12" E; 600 m a.s.1.; 24-26 Nov. 1999; A.V. Gorochov leg.; ZIN • $3 \mathrm{O}^{\lambda} \mathrm{O}^{\text {; }}$ s same collection data as for preceding; ZIN • 1 q; Pematang Siantar "Pem. Siantar", Research Centre? "Prapat Hutan Penelitian"; 10-1100 m a.s.1.; 10 Mar. 1993; S. Ingrisch leg.; SMTD

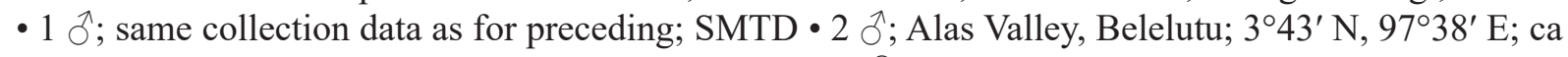
320 m a.s.1.; 3-8 Aug. 1972; J. Krikken leg.; RMNH 1 O; Alas Valley, vicinity of Gumpang; $3^{\circ} 48^{\prime}$ N, 97²9' E; 13 Jun. 1972; J. Krikken leg.; RMNH • 1 क ; Deli Sibolangit Nature Reserve; $3^{\circ} 19^{\prime}$ N, $98^{\circ} 35^{\prime}$ E; 500 m a.s.l.; 29 Jul. 1972; J. Krikken leg.; RMNH 1 人); Soban Ajam; Jul. 1916; E. Jacobson leg.; RMNH - 2 우; Kuala Simpang, lowland forest; 417'3.7" N, 98³'29" E; Jan. 1954; A. Sollaart leg.; RMNH • 1 ; Serdang, Tanjong Morawai; 1882; B. Hagen leg.; RMNH • 2 우; Sumatra Expedition 1877-1878 leg.; RMNH • 1 \%; Ketambe, at Jeb Tenggara; 341'6" N, 97²4'57" E; 350 m a.s.1.; 18 Nov. 1973; H.D. Rijksen

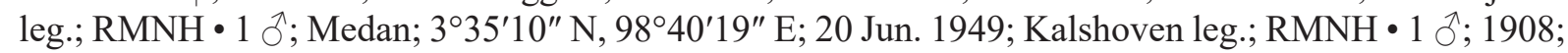

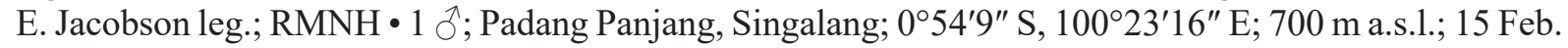
1995; H. Deumer and M. Schaarschmidt leg.; N5; MNHN-EO-ENSIF4180 • 2 qo+; 2 km from Padang Panjang (Taglang) [Talang?]; "3.9.1991”; Wolfram Guidatti leg.; MNHN • 2 ঐ̊ đ̂; [Lubu?] "Lubu Sampin”; 19 Jan. 1885; MHN • 1 q; [Lubu?] "Lubu Sampin"; 2 Dec. 1884; MHN • 2 q ; Padang in Batangproepoe "Pad. Bovenl”; 054'9" S, 100²3'16" E; Nov. 1924; C.B. K. and N. S. leg.; ZRC • 1 O’; Jambi “Djambi”; O. Posthumus leg.; MNHN • 1 万̃ ; "Habinsaran Tangga"; 2 Aug. 1928; J.C. v. d. MeerMohr leg.; MNHN

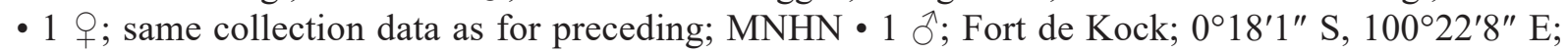
920 m a.s.l.; 1924; E. Jacobson leg.; MNHN • 1 juvenile; same collection data as for preceding; MNHN - 1 q; same collection data as for preceding; MNHN • 1 đ’; Soilak Daras, Korinchi Valley; $1^{\circ} 41^{\prime} 12^{\prime \prime}$ S, 101¹3'46" E; $3100 \mathrm{ft}$ a.s.1.; Mar. 1914; NHMUK • 1 क; Lut ["Laut" ] Tawar; 4³7'36" N, 9651'4" E; 1400 m a.s.1.; 23 Dec. 1929; H.T. Pagdan leg.; NHMUK・1 §’; Dohrn leg.; identified as Nisitrus hyalinus by L. Chopard; MNHN • 1 q; Dohrn leg.; MNHN • 1 क; Padang in Batangproepoe "Pad. Bovenl";

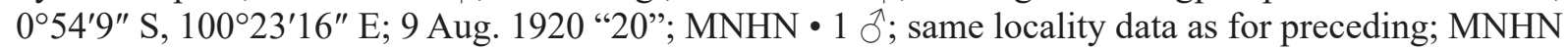
- 3 우; same locality data as for preceding; MNHN • $10^{\top}$; Medan; $3^{\circ} 35^{\prime} 10^{\prime \prime} \mathrm{N}, 98^{\circ} 40^{\prime} 19^{\prime \prime} \mathrm{E}$; Mjöberg leg.; GNME • 1 क; Dolok Baros; 1906; "Maindon" leg.; MNHN • 1 क; Medan Batu-Seri; 335'10" N, 98 40'19" E; 10 Mar. 1900; B. Jachan leg.; ZMH • 1 क; Deli; $3^{\circ} 19^{\prime}$ N, 98 $8^{\circ} 35^{\prime}$ E; 3 Jan. 1896; Gebr.

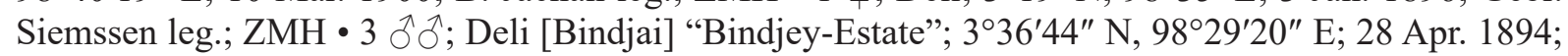
W. Burchard leg.; ZMH $\bullet 1$ क ; same collection data as for preceding; ZMH 1 ภ ; A. Grubauer leg.; ZMH $\bullet$

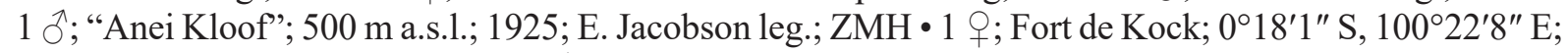

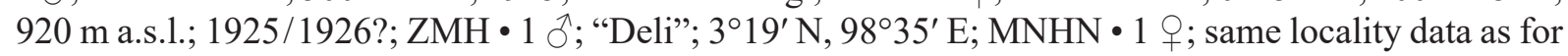

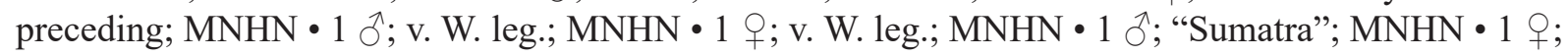
"Sumatra"; MNHN • 3 o ; ; Haran Kloof; 0²7'14.6" S, 101²4'53.192" E; 23 Apr. 1929; Prince Leopold

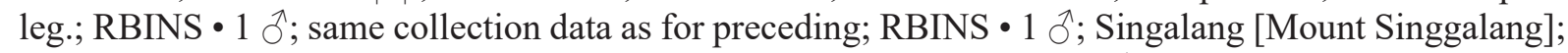
0²4'36" S, 100¹9'51" E; 23 Apr. 1929; Prince Leopold leg.; RBINS・1 ð’; Medan S.O.K. [Deli River];

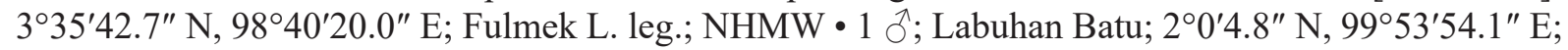
22 Sep. 2020; K.S. Zebua leg.; iNaturalist.org/observations/60403336・ 1 ภ; Labuhan Batu; $2^{\circ} 10^{\prime} 42.9^{\prime \prime} \mathrm{N}$, 9957'25.3" E; 6 Oct. 2020; K.S. Zebua leg.; iNaturalist.org/observations/61849044 • 1 ठ̊; Labuhan Batu; $2^{\circ} 08^{\prime} 7.3^{\prime \prime}$ N, 9952'59.2" E; 6 Oct. 2020; K.S. Zebua leg.; iNaturalist.org/observations/61849074

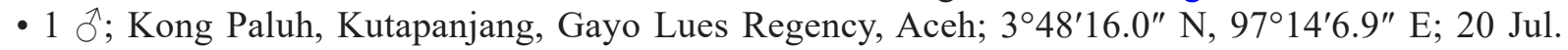
2018; G. Jarasunas leg.; iNaturalist.org/observations/20738568 • 1 क ; Kerinci, Jambi; $2^{\circ} 14^{\prime} 54.4^{\prime \prime}$ S, 101³2'21.3" E; 12 Aug. 2018; pmaaskant leg.; iNaturalist.org/observations/37307112 • 1 ठ; “Ланкат, Северная Суматра, Индонезия" [Langkat, North Sumatra, Indonesia]; 333'6.3" N, 986'37.2" E; 3 May 2019; reflectitur_photons leg.; iNaturalist.org/observations/25730568 • 1 \%; Lima Puluh Koto, ID-SB, ID; $0^{\circ} 6^{\prime} 39.0^{\prime \prime}$ S, 100 40'15.2" E; 6 Jun. 2011; D. Nys and M. Vancauwenbergh leg.; iNaturalist.org/observations/34083286 • 1 \%; Lubuk Landua; 06'19.5" N, 9953'12.3" E; 13 Mar. 2018; O. Johnson leg.; iNaturalist.org/observations/11018930 • 1 خ; Gayo Lues Regency, Aceh; 352'51.7" N, 97¹9'23.1" E; 21 May 2010; ninjawil leg.; iNaturalist.org/observations/9181395. 
MALAYSIA • 4 q $q$; “Camp Jor”, border between Perak and Pahang; 49'43" N, 102 22'20" E; 30 Dec. 1902; Alb. Grubauer leg.; ZMH.

\section{Redescription}

Slightly smaller than other species (Fig. 7D). Vivid yellow, brown and black when alive (Fig. 22A-C). Vertex variable: ranging from black with yellow margins around eyes (mostly in individuals from Sumatra) to cream-coloured with a strong longitudinal black band and one or two faint transverse black bands (forming a T- or cross-shaped black pattern; mostly in individuals from Siberut Islands and Malaysia) (Fig. 11E); dark pattern variable between individuals, some have a narrow pattern appearing more like a longitudinal band. Scapes red brown to black. Antennae red brown (individuals from Siberut) to black (individuals from Sumatra), with wide whitish rings. Frons yellow, cream-coloured to yellow, face part of fastigium brown to dark brown or black between eyes, lighter for individuals from Siberut than from Sumatra (Fig. 10E). Mouthparts dark brown to black in specimens from Sumatra, lighter or sometimes yellow in specimens from Siberut (Fig. 10E). Maxillary palpi cream-coloured; apical segment black apically (Fig. 10E). Head lateral side yellow to cream-coloured, including gena, with a black band posterior to eyes (Fig. 12E). Pronotum dorsal disk black, covered with white setae, rectangular with lateral margin barely widening posteriorly, posterior margin substraight to faintly bisinuous (Fig. 11E). Lateral lobes of pronotum dorsal half black, vivid yellow ventrally (cream-coloured in preserved specimens) (Fig. 12E). Legs generally light grey brown, sometimes with some small dark spots. FIIIs brown, with a brown longitudinal stripe along ventral half (more distinct and darker in individuals from Sumatra); sometimes dorsal margin with a paler longitudinal stripe; knees dark brown to black. TIIIs brown with black spines and spurs, dark brown to black near distal end; tarsomeres dark brown to black. Hindwings hyaline brown apically; longer than FWs and surpassing cerci, forming a black tail with yellow veins exceeding FWs for less than twice the length of the pronotum. Tergites red brown, with a pale band laterally; sternites pale, sometimes with a dark brown median area. Subgenital plate with a dark median area.

\section{Male}

FoREWINGS. FW colouration (Fig. 13D): dorsal field narrow, cells mostly transparent, veins varying from pale yellow to black. Basal area either infumated brown to black (individuals from Sumatra) or almost transparent (individuals from Siberut), but always with a cream-coloured triangular patch (sometimes more rounded). Chords most often with a white patch, most readily observed in individuals from Sumatra. R black, Sc projections black basally, cream-coloured or transparent apically. Lateral field transparent. FW venation (Fig. 13D): 1A curved, slightly angulated. Harp very small, slightly longer than wide, with one distinct straight oblique vein. $\mathrm{c} 1$ long and wide, broader basally; c2 diamond-shaped; mirror (d1) small, longer than wide, not rounded, generally separated into two parts by a transverse vein, the anterior part triangular, about as long as posterior part, posterior part rectangular. Cell $\mathrm{d} 2$ about as wide as $\mathrm{d} 1$, usually subdivided by accessory veins. Apical field short, including one cell alignment posterior to mirror and a narrow apical alignment; its veins cream-coloured. Lateral field transparent, with 5 or 6 projections of Sc. Epiproct black. Subgenital plate with a dark median area. Cerci red brown.

Genitalia (Fig. 16D). Pseudepiphallus sclerotized, stout (medium-sized but broad) compared to congeners, anterior margin somewhat broad and straight, posterior margin also straight, lateral margins faintly converging posteriorly. Posterior apex with paired lophi slightly longer than wide (at base), obtuse at apex, moderately spaced apart from one another. Rami swollen preapically, anterior apex somewhat truncated. Pseudepiphallic parameres narrow. Ectophallic fold rounded lateral sclerites appearing beanshaped to rectangular. Endophallic sclerite wide and rounded laterally, with relatively long lateral arms.

\section{Female}

ForEWINGS. FW colouration (Fig. 14E): base of dorsal field with a yellow area; cells black, veins mostly vivid yellow (cream-coloured in preserved specimens). Region of $\mathrm{CuA}, \mathrm{M}$ and $\mathrm{R}$ black, including the 
veins. Sc projections yellow basally, black apically. Lateral field transparent. FW venation: 6-7 strong longitudinal veins on dorsal field; lateral field with 6 projections of Sc.

GeNITALIA. Ovipositor slightly longer than FIII. Copulatory papilla conical, smaller and stout; apex folded ventrally, stout, broader than congeners, pointed; dorsal face with a sclerotized area, forming a somewhat triangular rim (Fig. 17H-I).
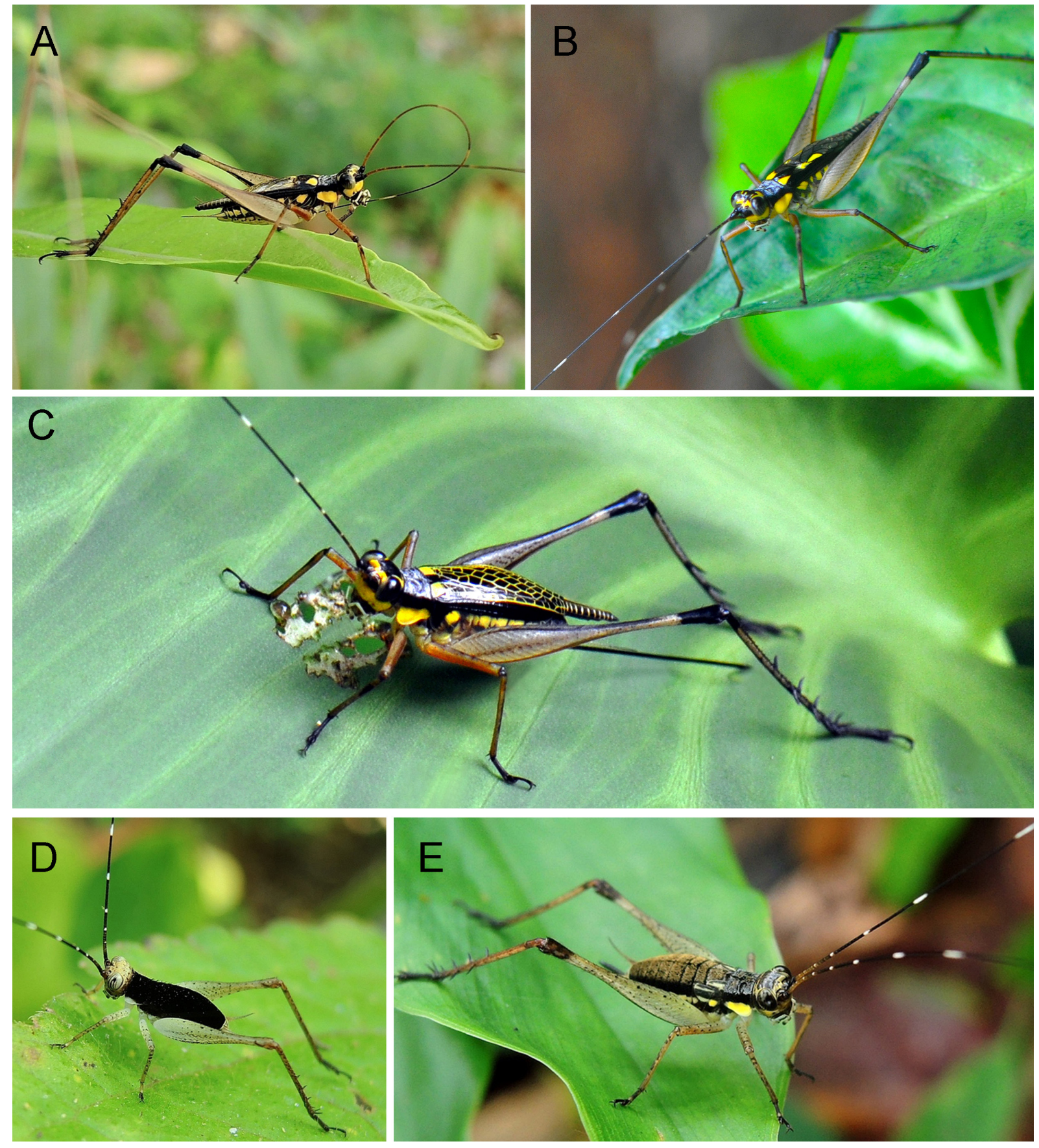

Fig. 22. Nisitrus insignis Saussure, 1878 in its natural environment. A-B. Adult $\widehat{\partial}$ đ. C. Adult $q$. D-E. Nymphs. Photograph source and credits: iNaturalist; Michael Kesl (A, D-E), Oscar Johnson (B), Dries Nys and Marion Vancauwenbergh (C). 
TAN M.K. et al., Revision of Nisitrus (Orthoptera: Eneopterinae)

Table 7. Measurements of Nisitrus insignis Saussure, 1878 (in mm, means in brackets).

\begin{tabular}{|c|c|c|c|c|c|c|c|c|}
\hline & PronL & PronW & FWL & FWW & HWT & FIIIL & FIIIW & TIIIL \\
\hline Males $(n=5)$ & $\begin{array}{c}1.7-2.4 \\
(2.0)\end{array}$ & $\begin{array}{c}2.5-3.2 \\
(2.8)\end{array}$ & $\begin{array}{c}7.3-9.5 \\
(8.7)\end{array}$ & $\begin{array}{c}2.5-2.9 \\
(2.8)\end{array}$ & $\begin{array}{c}3.4-4.6 \\
(3.8)\end{array}$ & $\begin{array}{c}13.9-16.3 \\
(15)\end{array}$ & $\begin{array}{c}2.3-2.9 \\
(2.6)\end{array}$ & $\begin{array}{c}14.3-19.4 \\
(15.8)\end{array}$ \\
\hline \multirow[t]{3}{*}{ Females $(\mathrm{n}=5)$} & $\begin{array}{c}2.1-2.5 \\
(2.2)\end{array}$ & $\begin{array}{c}2.9-3.5 \\
(3.1)\end{array}$ & $\begin{array}{c}10.2-11.4 \\
(10.7)\end{array}$ & $\begin{array}{c}3.0-3.7 \\
(3.3)\end{array}$ & $\begin{array}{c}3.7-4.6 \\
(4.2)\end{array}$ & $\begin{array}{c}16.3-17.6 \\
(17.0)\end{array}$ & $\begin{array}{c}2.7-3.2 \\
(3.0)\end{array}$ & $\begin{array}{c}15.6-18.2 \\
(16.9)\end{array}$ \\
\hline & & Dorsal sp & nes of TIII & & & & & \\
\hline & Ias & Ibs & Oas & Obs & TaIIIs & \multicolumn{2}{|c|}{ OL } & \\
\hline Males $(n=5)$ & $\begin{array}{c}13-15 \\
(14)\end{array}$ & $2-4$ & $\begin{array}{c}19-21 \\
(20)\end{array}$ & $2-6$ & $2-3$ & \multicolumn{2}{|c|}{-} & \\
\hline Females $(\mathrm{n}=5)$ & $\begin{array}{c}13-15 \\
(14)\end{array}$ & $2-5$ & $\begin{array}{c}19-20 \\
(20)\end{array}$ & $2-5$ & 2 & \multicolumn{2}{|c|}{$\begin{array}{c}15.7-17.7 \\
(16.7)\end{array}$} & \\
\hline
\end{tabular}

\section{Juvenile (Fig. 22D-E)}

Young instar with head nearly completely cream-coloured. Pronotum disk velvety black, lateral lobe with dorsal half velvety black and ventral half cream-coloured. Legs generally cream-coloured with small dark spots; tarsi darker. Abdomen with tergites velvety black dorsally, with sternites cream-coloured ventrally. Epiproct cream-coloured. Later instar resembles adult colouration.

\section{Measurements}

See Table 7.

\section{Ecology}

Habitat and mating behaviour, including multiple mating, male guarding behaviour, female eating spermatophores and male-male competition for females, were described in detail by Preston-Mahfam (2000).

\section{Distribution}

Sumatra, Malay Peninsula (Malaysia).

\section{Type locality}

Indonesia: Sumatra.

\section{Calling song}

Unknown.

\section{Remarks}

One syntype of Saussure from Northern Sumatra found in NMW is designated here as the lectotype of the species. Based on comparisons with the type of $N$. sumatrensis, the latter name is considered as a junior synonym of $N$. insignis (new synonymy, see below).

The observed specimen series vary greatly in size and colouration, which made us hesitate between defining one or more species, in particular for the lighter specimens from the Mentawai Islands. To remain conservative, we considered these differences as species variation only, but more information about molecular divergence and acoustic parameters may lead to revise this decision in future studies. 


\section{Nisitrus malaya Robillard \& Tan sp. nov. urn:lsid:zoobank.org:act:AD6647DB-81AE-421B-8433-C4E3D9ACC314}

Figs 4-5, 7E, 9A, 10F, 11F, 12F, 13E, 14F, 16E, 17J-K, 23A-D, 24A-C, 25A-C, 26; Tables 1-2, 8

Nisitrus vittatus - Robillard \& Desutter-Grandcolas 2004a: 276; 2004b: 578; 2004c: 304; 2006: 644; 2008: 67 (Nisitrini tribe); 2011: 637. — Robillard et al. 2007: 1265; 2013: 2002 (mechanism of stridulation). - Desutter-Grandcolas et al. 2010: 616. — Nattier et al. 2011: 2201 (phylogeny and molecular dating). — Tan 2012: 4; 2017: 4. — Tan et al. 2012: 66; 2013a: 220; 2013b: 99; 2015: 47; 2017: 146 (flower-visiting behaviour). — Robillard \& Tan 2013: 707. — Tan \& Robillard 2014: 375. — ter Hofstede et al. 2015: 3245-3252 (communication). - Schneider et al. 2017: 1-12 (tympanum structure).

\section{Diagnosis}

Average size, colouration contrasting with black and yellow, characterised by black vertex, yellow frons and orange brown legs. This new species is very close to $N$. vittatus from which it differs by adult and juvenile colouration, male and female genitalia and calling song. General colouration darker, particularly among FW cells and veins beneath R; R black (instead of cream-coloured as in N. vittatus); in male venation, anal-most and middle chords narrow and nearly parallel with one another (instead of diverging apically), and basal-most chord extend from basal half of middle chord (instead of at/after midpoint). It differs from $N$. vittatus by the male genitalia with pseudepiphallus more robust, broad, anterior margin more strongly concave. Female copulatory papilla with truncated lobule at the ventro-anterior end. Juvenile differs strikingly in the body colour pattern. Male calling song also differs by longer echeme period. This species is also similar to N. crucius sp. nov. in size and habitus, but differs by the absence of cross-shaped black pattern on frons and does not occur in Borneo.

\section{Etymology}

This specific name is a noun in apposition referring to the species' distribution in the Malay Peninsula (including Singapore and Peninsular Malaysia).

\section{Material examined}

\section{Holotype}

SINGAPORE • ○’; Dairy Farm Nature Park; $1^{\circ} 21^{\prime} 44^{\prime \prime}$ N, 10346'9" E; 17 Jul. 2020; M.K. Tan leg.; ZRC.

\section{Paratypes}

MALAYSIA - Selangor • $1 \partial^{\prime}$; Petaling Jaya, Mount Kiara; $3^{\circ} 10^{\prime} 17.44^{\prime \prime} \mathrm{N}, 101^{\circ} 38^{\prime} 42.70^{\prime \prime}$ E; 7 Sep. 2002; T. Robillard leg.; MNHN-EO-ENSIF3132 • 1 ऊ ; same collection data as for preceding; call recording; MNHN-EO-ENSIF3133• 1 ô; same collection data as for preceding; MNHN-EO-ENSIF3134 • 1 ; ; same collection data as for preceding; MNHN-EO-ENSIF11140 • 1 \%; same locality data as for preceding; Aug. 2002; T. Robillard leg.; MNHN-EO-ENSIF11331・1 ; same locality data as for preceding; T. Robillard leg.; PIII: Nvith2; MNHN-EO-ENSIF1708・1 ð̋; 1909; C.J. Brooks leg.; NHMUK.

SINGAPORE • 1 ðં; Bukit Timah, "près de l'entrée de la réserve" [near entrance]; $1^{\circ} 21^{\prime} 6.7^{\prime \prime} \mathrm{N}$, 10346'45.2" E; 92 m a.s.1.; 10 Jun. 2011; T. Robillard leg.; call recording; MNHN-EO-ENSIF3136 • 1 o'; Bukit Timah, "sommet" [summit]; 1²1'16.2" N, 10346'35.9" E; 170 m a.s.1.; 29 Jun. 2009; T. Robillard leg.; call recording MNHN-SO-2016-41; TR9; MNHN-EO-ENSIF3102・ 1 ; ; same locality data as for preceding; 10 Jun. 2011; T. Robillard leg.; TR1; MNHN-EO-ENSIF10948 • 1 đ; Bukit Timah Nature Reserve, Hindhede Trail; $1^{\circ} 20^{\prime} 57.1^{\prime \prime}$ N, 10346'45.2" E; 68 m a.s.1.; 20 Jun. 2011; T. Robillard leg.; TR26;

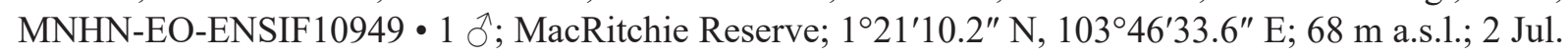
2009; T. Robillard leg.; call recording; MNHN-EO-ENSIF3135 • 1 ' ; MacRitchie Reserve; $1^{\circ} 21^{\prime} 10.2^{\prime \prime} \mathrm{N}$,

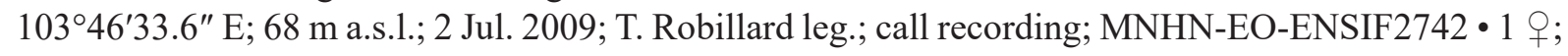


TAN M.K. et al., Revision of Nisitrus (Orthoptera: Eneopterinae)

Mandai; 1²4'52.7" N, 10347'22.2" E; 27 Dec. 2015; M.K. Tan and H. Yeo leg.; C2.F.50; MNHN-EOENSIF11136 • 1 q; same collection data as for preceding; C2.F.51; MNHN-EO-ENSIF11138・1 $\circ$; same collection data as for preceding; C2.F.28; MNHN-EO-ENSIF11137.

\section{Additional specimens}

MALAYSIA • 6 juveniles; Petaling Jaya, Mount Kiara; $3^{\circ} 10^{\prime} 17.44^{\prime \prime}$ N, 101 $1^{\circ} 38^{\prime} 42.70^{\prime \prime}$ E; 7 Sep. 2002; T. Robillard leg.; MNHN 1 juvenile; Kepong FRIM (Forest Research Insitute of Malaysia); $3^{\circ} 13^{\prime} 60^{\prime \prime} \mathrm{N}$,

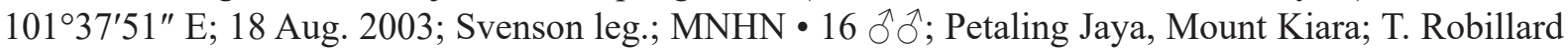
leg.; élevage; MNHN • 11 q ; same collection data as for preceding; MNHN • 1 + ; PD Villa Country Resort, 11, Jln PDV 3, Taman Rakyat, 71050 Teluk Kemang, Negeri Sembilan; 2²7'27.3" N, 101 '52'5.9" E; 17 Feb. 2019; J. Howes leg.; iNaturalist.org/observations/20414064 • 1 क; Bestari Jaya, Selangor; $3^{\circ} 16^{\prime} 7^{\prime \prime}$ N, 101²7'28.6" E; 27 Apr. 2019; S. Siva Perumal leg.; iNaturalist.org/observations/24568214

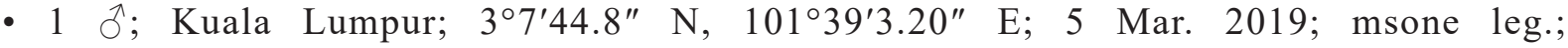

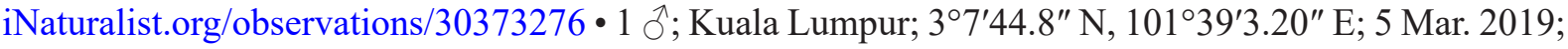

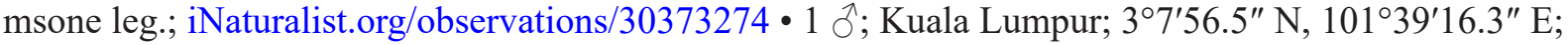
9 Jan. 2019; msone leg.; iNaturalist.org/observations/20052999 • 1 क; Kledong Saiong Forest Eco Park, Perak; 440'59.7" N, 101²' 6.5" E; 25 Jul. 2019; K. Wenyuh leg.; iNaturalist.org/observations/29510836 • 1 q; Bukit Gasing, Petaling Jaya, Selangor; 35'54.3" N, 101³9'29.1" E; 17 Nov. 2006; J. Howes leg.; iNaturalist.org/observations/35667227 • 1 ô; Taman Tugu PT88, Jalan Sultan Salahuddin, Kuala Lumpur, 50480 Kuala Lumpur Federal Territory of Kuala Lumpur; 39'6.28" N, 101 ${ }^{\circ} 41^{\prime} 0.900^{\prime \prime}$ E; 17 Nov. 2019; T. Maul leg.; iNaturalist.org/observations/35769550 • 1 क; Semenyih, Selangor; $2^{\circ} 56^{\prime} 36.2^{\prime \prime} \mathrm{N}, 101^{\circ} 54^{\prime} 4^{\prime \prime}$ E; 3 Dec. 2019; B.C.A. Howes leg.; iNaturalist.org/observations/36316633•1 ô; Bukit Persekutuan, Kuala Lumpur, Federal Territory of Kuala Lumpur; 3 $8^{\prime 2} 21.3^{\prime \prime}$ N, 101 $40^{\prime} 50.6^{\prime \prime}$ E; 11 Jul. 2007; J. Howes leg.; iNaturalist.org/observations/36663502 • 1 \%; Lot 240, Jalan Raja Chulan, Kuala Lumpur, 50250 Kuala Lumpur, Wilayah Persekutuan Kuala Lumpur; $3^{\circ} 9^{\prime} 3.28^{\prime \prime}$ N, 101 $42^{\prime} 7.5^{\prime \prime}$ E; 6 Jan. 2020; T. Maul leg.; iNaturalist.org/observations/37332417 • 1 q; 31600, Perak; 4²7'29.1" N, 101²12'30.5" E; 4 Jan. 2020; M. Ng leg.; iNaturalist.org/observations/37357322 - 1 क; Hutan Lipur Sungai Tua; 320'1.2" N, $101^{\circ} 43^{\prime 2} 26.1^{\prime \prime}$ E; 6 Oct. 2014; T. Kirschey leg.; iNaturalist.org/observations/49430837・ 1 \&; unnamed road, Kampung Padang, 43100 Hulu Langat, Selangor; $3^{\circ} 11^{\prime} 55.2^{\prime \prime}$ N, 10151'4" E; 11 Jan. 2020; F. Cheong leg.; iNaturalist.org/observations/37615383 • 1 ơ; Beranang, Selangor; 256'17.8” N, 101 ${ }^{\circ} 53^{\prime} 56.2^{\prime \prime}$ E; 19 Jan. 2020; M.A.M. Nasir leg.; iNaturalist.org/observations/37730365 • 1 q; Kampung Tanjung Jelai, Jerantut, Pahang; 4 $4^{\prime} 11.1^{\prime \prime} \mathrm{N}, 102^{\circ} 19^{\prime} 0^{\prime \prime}$ E; 20 Feb. 2019; djhiker leg.; iNaturalist.org/observations/24363726

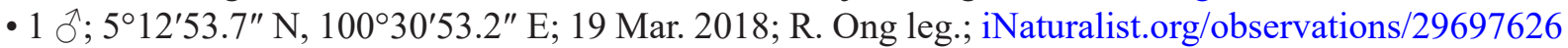
- $1 \mathrm{O}^{\top}$; 53100 Kuala Lumpur, Federal Territory of Kuala Lumpur; $3^{\circ} 13^{\prime} 53.1^{\prime \prime} \mathrm{N}, 101^{\circ} 44^{\prime} 25.8^{\prime \prime}$ E; 15 Feb.

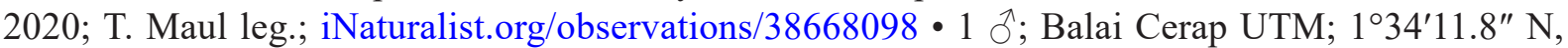

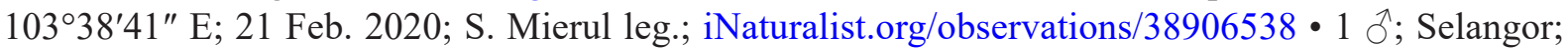
$3^{\circ} 35^{\prime} 39.6^{\prime \prime} \mathrm{N}, 101^{\circ} 44^{\prime} 5.9^{\prime \prime}$ E; 28 Jul. 2019; msone leg.; iNaturalist.org/observations/39490018 • 1 ᄋ;

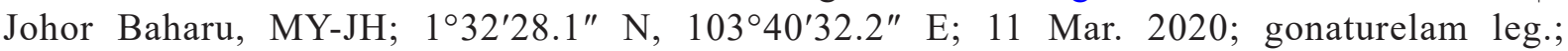
iNaturalist.org/observations/39833380 • $10^{\circ} ; 2^{\circ} 50^{\prime} 40.7^{\prime \prime} \mathrm{N}, 1^{\circ} 1^{\circ} 56^{\prime} 32.2^{\prime \prime}$ E; 1 May 2019; anukma leg.; iNaturalist.org/observations/24256308 • 1 juvenile; Taman Tugu PT88, Jalan Sultan Salahuddin, Kuala Lumpur, 50480 Kuala Lumpur, Federal Territory of Kuala Lumpur; $3^{\circ} 9^{\prime} 6.28^{\prime \prime} \mathrm{N}, 101^{\circ} 41^{\prime} 0.900^{\prime \prime} \mathrm{E}$; 17 Nov. 2019; T. Maul leg.; iNaturalist.org/observations/35769588 • 1 q; Mersing, Johor; $2^{\circ} 25^{\prime} 7.56^{\prime \prime}$ N, 103 ${ }^{\circ}$ 51'22.8" E; 7 Feb. 2020; msone leg.; iNaturalist.org/observations/38427233 • 1 juvenile; Tamarind Springs Jalan 1, Taman Tun Abdul Razak, 68000 Ampang Jaya, Selangor; $3^{\circ} 10^{\prime} 14.6^{\prime \prime} \mathrm{N}, 101^{\circ} 46^{\prime} 14.3^{\prime \prime}$ E; 21 Jun. 2020; T. Maul leg.; iNaturalist.org/observations/50422192 • 1 juvenile; Selama; 5¹3'6.5" N, 10041'36.5" E; 5 Jul. 2020; M. Syarifudin leg.; iNaturalist.org/observations/51984928 • 1 juvenile; Tamarind Springs Jalan 1, Taman Tun Abdul Razak, 68000 Ampang Jaya, Selangor; $3^{\circ} 10^{\prime} 14.6^{\prime \prime}$ N, $101^{\circ} 46^{\prime} 14.3^{\prime \prime}$ E; 5 Sep. 2020; T. Maul leg.; iNaturalist.org/observations/58822053 • 1 ठ; Bentong, Pahang, MY; 3¹8'47.2" N, 10152'49.6" E; 12 Sep. 2020; J. Marriappan leg.; iNaturalist.org/observations/59301449 - 1 juvenile; Tamarind Springs Jalan 1, Taman Tun Abdul Razak, 68000 Ampang Jaya, Selangor; 
$3^{\circ} 10^{\prime} 14.6^{\prime \prime}$ N, 10146'14.3" E; 19 Sep. 2020; T. Maul leg.; iNaturalist.org/observations/60070623 • 1 \%; Jalan Melawati 5, Taman Zoo View, Selangor, MY; 313'0.400" N, 101 ${ }^{\circ} 45^{\prime} 2^{\prime \prime}$ E; 2 Sep. 2020; K.J.M. Anbumani leg.; iNaturalist.org/observations/60166965 • 1 juvenile; Taman Bukit Perdana, 83000 Batu Pahat, Johor; 1०50'53.6" N, 10257'37.3" E; 26 Sep. 2020; J. Neo leg.;

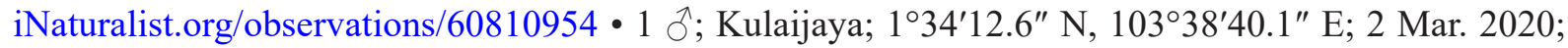
A. Zaidi leg.; iNaturalist.org/observations/39477877 1 juvenile; Tamarind Springs Jalan 1, Taman Tun Abdul Razak, 68000 Ampang Jaya, Selangor; $3^{\circ} 10^{\prime} 14.6^{\prime \prime}$ N, 101²46'14.3" E; 8 Mar. 2020; T. Maul leg.; iNaturalist.org/observations/39698484 • 1 ô'; UTM Skudai, Johor Bahru; 1³3'26.3" N, 10338'14.1" E; 29 Apr. 2020; B. Kumpau leg.; iNaturalist.org/observations/44237939 • 1 juvenile; Kuala Lumpur, 50480 Kuala Lumpur, Federal Territory of Kuala Lumpur; 3ㅇ'23.1" N, 101 ${ }^{\circ} 41^{\prime} 5.9^{\prime \prime}$ E; 26 May 2020; H. Shanmugam leg.; iNaturalist.org/observations/47737528 • 1 \% ; $2^{\circ} 48^{\prime} 23.6^{\prime \prime}$ N, $101^{\circ} 52^{\prime 2} 20.3^{\prime \prime}$ E; 3 May 2020; anukma leg.; iNaturalist.org/observations/47829023 • 1 ô; Klinik Kesihatan Sungai Lembing,

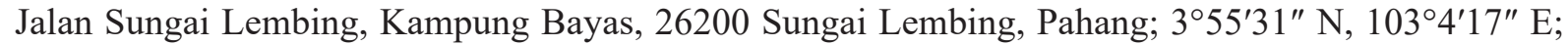
7 Jun. 2020; A. Yusuf leg.; iNaturalist.org/observations/48735148 1 क; Perdana Botanical Gardens, Kuala Lumpur, Federal Territory of Kuala Lumpur; 38'41.7" N, 101²41'10.6" E; 19 Jun. 2020; N. Rahman leg.; iNaturalist.org/observations/50133159 • 1 ; ; Tamarind Springs Jalan 1, Taman Tun Abdul Razak, 68000 Ampang Jaya, Selangor; 3¹0'14.6" N, 10146'14.3" E; 20 Jun. 2020; T. Maul leg.; iNaturalist.org/observations/50276251 • $10^{\top}$; Seberang Perai Selatan; 5०17'13.6" N, 100³0'30" E; 5 Jul. 2020; alexiuslzl leg.; iNaturalist.org/observations/52006113 • 1 q; KJ75 Pertubuhan Peladang, Pekan Batu 14 Hulu Langat, 43100 Hulu Langat, Selangor; 36'50.1" N, 101 ${ }^{\circ} 48^{\prime} 56.3^{\prime \prime}$ E; 19 Jul. 2020; S. Saphian leg.; iNaturalist.org/observations/53567997 • 1 juvenile; Batu Pahat, Johor; ${ }^{\circ} 50^{\prime 2} 28^{\prime \prime}$ N, 102 57'36.8" E; 31 Jul. 2020; diclim_eschsbp leg.; iNaturalist.org/observations/54914512 • 1 ơ; Taman Bukit Perdana, 83000 Batu Pahat, Johor; $1^{\circ} 50^{\prime} 53.6^{\prime \prime}$ N, 102 57'37.3" E; 31 Jul. 2020; ziki_eschsbp leg.; iNaturalist.org/observations/54932721 • 1 juvenile; NCP, Taman Tugu, Kuala Lumpur; $3^{\circ} 9^{\prime} 4.4^{\prime \prime}$ N, 101 41'8.13" E; 9 Aug. 2020; T. Maul leg.; iNaturalist.org/observations/55895941 • 1 \&; NCP, Taman Tugu, Kuala Lumpur; 39'4.4" N, 101 $41^{\prime} 8.13^{\prime \prime}$ E; 9 Aug. 2020; T. Maul leg.; iNaturalist.org/observations/55896227 • 1 juvenile; Jalan Perdana 17, Taman Bukit Perdana, 83000 Batu Pahat, Johor; 1 ${ }^{\circ} 50^{\prime} 53.7^{\prime \prime}$ N, 102 ${ }^{\circ} 7^{\prime} 37.7^{\prime \prime}$ E; 16 Aug. 2020; ziki_eschsbp leg.; iNaturalist.org/observations/56605014 • 1 o, 1 ○; Jalan Perdana 17, Taman Bukit Perdana, 83000 Batu Pahat, Johor; 150'53.7" N, 102 57'37.7" E; 16 Aug. 2020; ziki_eschsbp leg.; iNaturalist.org/observations/56605016 1 juvenile; Taman Bukit Indah, 68000 Ampang Jaya, Selangor; $3^{\circ} 9^{\prime} 34.7^{\prime \prime} \mathrm{N}, 101^{\circ} 46^{\prime} 34.3^{\prime \prime} \mathrm{E}$; 20 Aug. 2020; T. Maul leg.; iNaturalist.org/observations/57008216 • 1 '; Taman Bukit Perdana, 83000 Batu Pahat, Johor; 150'53.6" N, 102 ${ }^{\circ} 57^{\prime} 37.3^{\prime \prime}$ E; 20 Aug. 2020; ziki_ eschsbp leg.; iNaturalist.org/observations/57014573 • 1 क; 83200 Senggarang, Johor; $1^{\circ} 46^{\prime} 20^{\prime \prime} \mathrm{N}$, 103¹'33.1" E; 22 Aug. 2020; ziki_eschsbp leg.; iNaturalist.org/observations/57193924・1 §’; Taman Bukit Perdana 2, 83000 Batu Pahat, Johor; $1^{\circ} 50^{\prime} 32.8^{\prime \prime}$ N, 102 ${ }^{\circ} 57^{\prime} 15^{\prime \prime}$ E; 20 Aug. 2020; tstan_eschsbp leg.; iNaturalist.org/observations/57307974 • 1 O; NCP, Taman Tugu, Kuala Lumpur; 3० $9^{\prime} 4.4^{\prime \prime}$ N, 101 ${ }^{\circ} 41^{\prime} 8.13^{\prime \prime}$ E; 23 Aug. 2020; T. Maul leg.; iNaturalist.org/observations/57311814 • 1 juvenile; Jalan Cenderasari, Kuala Lumpur; $3^{\circ} 8^{\prime} 44.6^{\prime \prime} \mathrm{N}, 101^{\circ} 41^{\prime} 18.5^{\prime \prime}$ E; 30 Aug. 2020; mengarooo leg.; iNaturalist.org/observations/58026678 1 juvenile; Tamarind Springs Jalan 1, Taman Tun Abdul Razak, 68000 Ampang Jaya, Selangor; 3¹0'14.6" N, 101 46'14.3" E; 31 Aug. 2020; T. Maul leg.; iNaturalist.org/observations/58233139 • 1 \%; 83200 Senggarang, Johor; $1^{\circ} 44^{\prime} 6.4^{\prime \prime} \mathrm{N}, 103^{\circ} 4^{\prime} 1.2^{\prime \prime} \mathrm{E}$; 22 Aug. 2020; J. Neo leg.; iNaturalist.org/observations/58578339 • 1 §’; Choa Chu Kang Park; $1^{\circ} 23^{\prime} 11.9^{\prime \prime} \mathrm{N}, 103^{\circ} 44^{\prime} 51^{\prime \prime}$ E; 6 Sep. 2020; mingwei leg.; iNaturalist.org/observations/58695507 • 1 ठ, 1 †; Tamarind Springs Jalan 1, Taman Tun Abdul Razak, 68000 Ampang Jaya, Selangor; $3^{\circ} 10^{\prime} 14.6^{\prime \prime}$ N, $101^{\circ} 46^{\prime} 14.3^{\prime \prime}$ E; 5 Sep. 2020; T. Maul leg.; iNaturalist.org/observations/58826217 • 1 \%; Ampang Jaya, Selangor; $3^{\circ} 13^{\prime} 0.100^{\prime \prime} \mathrm{N}, 101^{\circ} 45^{\prime} 3.5^{\prime \prime}$ E; 20 Sep. 2020; B. Sg leg.; iNaturalist.org/observations/60147373

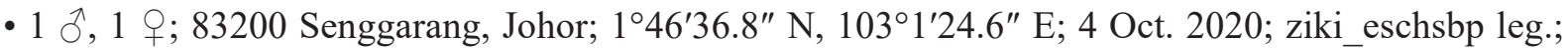
iNaturalist.org/observations/61669789 • 1 juvenile; 83200 Senggarang, Johor; $1^{\circ} 46^{\prime} 36.8^{\prime \prime} \mathrm{N},{ }_{103^{\circ}} 1^{\prime} 24.6^{\prime \prime} \mathrm{E}$; 4 Oct. 2020; ziki_eschsbp leg.; iNaturalist.org/observations/61669797 • 1 §̊; Garden Avenue, 70300 
Seremban, Negeri Sembilan; 240'39.7" N, 10154'2.70" E; 7 Oct. 2020; O.J. Seng leg.; iNaturalist.org/observations/61917637 • 1 §ं; Garden Avenue, 70300 Seremban, Negeri Sembilan; $2^{\circ} 40^{\prime} 53^{\prime \prime}$ N, 101 53 '56.2" E; 7 Oct. 2020; O.J. Seng leg.; iNaturalist.org/observations/61920273• 1 juvenile; Bukit Kiara, 60000 Kuala Lumpur, Federal Territory of Kuala Lumpur; $3^{\circ} 9^{\prime} 12^{\prime \prime}$ N, $101^{\circ} 38^{\prime} 11^{\prime \prime}$ E; 8 Oct. 2020; V. Ganesh leg.; iNaturalist.org/observations/62013556 • 1 juvenile; Kuala Lumpur, Federal Territory of Kuala Lumpur; 3 ${ }^{\circ} 8^{\prime} 20.3^{\prime \prime}$ N, 101 $41^{\prime} 12.6^{\prime \prime}$ E; 8 Oct. 2020; C.W. Chun leg.; iNaturalist.org/observations/62037651 • 1 \%; Perdana Botanical Gardens, Kuala Lumpur, Federal Territory of Kuala Lumpur; 3०8'37.2" N, 101 $41^{\prime} 9.9^{\prime \prime}$ E; 8 Oct. 2020; C.W. Chun leg.; iNaturalist.org/observations/62075913 • 1 ㅇ; $1^{\circ} 50^{\prime} 33.5^{\prime \prime} \mathrm{N}, 102^{\circ} 57^{\prime} 38.2^{\prime \prime} \mathrm{E} ; 10$ Oct. 2020; joyce tan leg.; iNaturalist.org/observations/62628458 • 1 juvenile; Petaling Jaya, Selangor; $3^{\circ} 10^{\prime} 33.6^{\prime \prime} \mathrm{N}$, $101^{\circ} 36^{\prime} 31.1^{\prime \prime}$ E; 25 Oct. 2020; msone leg.; iNaturalist.org/observations/63555073 • 1 juvenile; Petaling Jaya, Selangor; $3^{\circ} 10^{\prime} 33.6^{\prime \prime} \mathrm{N}, 101^{\circ} 36^{\prime} 31.1^{\prime \prime} \mathrm{E}$; 25 Oct.2020; msoneleg.; iNaturalist.org/observations/63555074 - 1 juvenile; Perdana Botanical Gardens, Kuala Lumpur, Federal Territory of Kuala Lumpur; $3^{\circ} 8^{\prime} 37.2^{\prime \prime}$ N, 10141'9.9" E; 8 Oct. 2020; C.W. Chun leg.; iNaturalist.org/observations/62078581 • 1 ô, 1 क ; Gombak; $3^{\circ} 15^{\prime} 41.7^{\prime \prime} \mathrm{N}, 101^{\circ} 38^{\prime} 7^{\prime \prime}$ E; 28 Apr. 2019; Y. Joyce leg.; iNaturalist.org/observations/23581051 • 1 juvenile; Gunung Lambak; $2^{\circ} 1^{\prime} 39^{\prime \prime}$ N, $103^{\circ} 21^{\prime 2} 27^{\prime \prime}$ E; 2 Aug. 2020; howe leg.; iNaturalist.org/observations/55174550 - 1 क; Kuala Terengganu; 5 16 $^{\prime} 55^{\prime \prime}$ N, 1036'32" E; 27 Dec. 2013; Lanzz leg.; https://www.projectnoah. org/spottings/130726139?fbclid=IwAR1CsvK9ownDvtCZtRiad51j9dnh3aKasTEVLyyZGkwfXm1PNj dkKMrq-TM.

SINGAPORE - 1 juvenile; Central Catchment Nature Reserve, "sentier forestier"; $1^{\circ} 22^{\prime} 49^{\prime \prime} \mathrm{N}$,

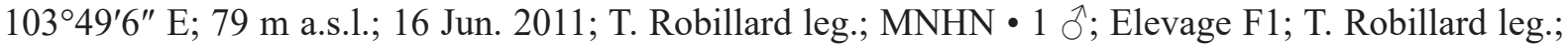

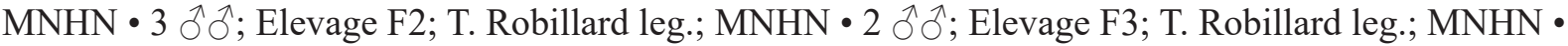

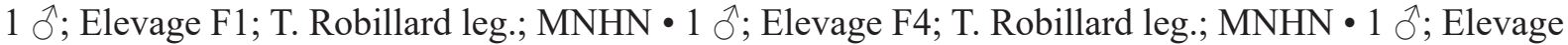

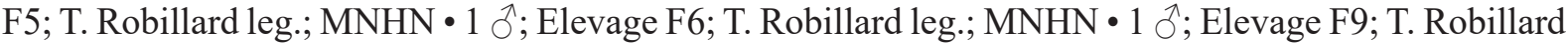

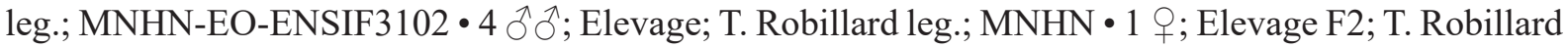
leg.; MNHN • 1 क; Elevage F3; T. Robillard leg.; MNHN • 1 क; Elevage F5; T. Robillard leg.; MNHN - 3 웅 Elevage; T. Robillard leg.; MNHN • 1 + ; Lim Chu Kang; $1^{\circ} 26^{\prime} 46.1^{\prime \prime}$ N, $103^{\circ} 43^{\prime} 45.7^{\prime \prime}$ E; 26 Dec. 2019; E.C. Maxwell leg.; iNaturalist.org/observations/39013226• 1 ठ̊;; Blackmore Drive, Holland Village; $1^{\circ} 19^{\prime} 59.8^{\prime \prime} \mathrm{N}, 103^{\circ} 46^{\prime} 53.1^{\prime \prime} \mathrm{E} ; 27$ Oct. 2020; stefaniek leg.; iNaturalist.org/observations/63613982 • 1 o'; Central Water Catchment; $1^{\circ} 20^{\prime} 48.2^{\prime \prime} \mathrm{N}, 103^{\circ} 50^{\prime} 8.5^{\prime \prime} \mathrm{E} ; 10$ Apr. 2020; M. Finlay leg.;

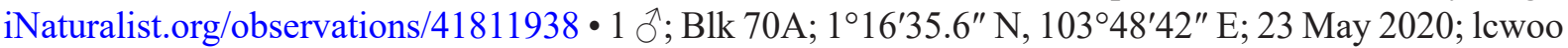
leg.; iNaturalist.org/observations/46927932 • 1 क; Woodlands (SLE) Park Connector, Woodlands; $1^{\circ} 25^{\prime} 36.7^{\prime \prime} \mathrm{N}, 103^{\circ} 47^{\prime} 14.3^{\prime \prime} \mathrm{E}$; 29 May 2020; looiec leg.; iNaturalist.org/observations/47701690 • 1 \%; Champions Way, Woodlands; $1^{\circ} 25^{\prime} 40.1^{\prime \prime} \mathrm{N}, 103^{\circ} 47^{\prime} 16.8^{\prime \prime}$ E; 29 May 2020; looiec leg.; iNaturalist.org/observations/47701715 • 1 juvenile; 36C Lor Halwa 298637; $1^{\circ} 20^{\prime} 10^{\prime \prime} \mathrm{N}, 103^{\circ} 49^{\prime} 22.6^{\prime \prime} \mathrm{E}$; 9 May 2020; flyingswallow123 leg.; iNaturalist.org/observations/48998890 • 1 +; Tanglin; $1^{\circ} 18^{\prime} 2.5^{\prime \prime} \mathrm{N}$, $103^{\circ} 48^{\prime} 41.1^{\prime \prime}$ E; 15 Jun. 2020; D. Rham leg.; iNaturalist.org/observations/49656881 • 1 đं; Yishun; $1^{\circ} 24^{\prime} 51.7^{\prime \prime} \mathrm{N}, 103^{\circ} 50^{\prime} 34.2^{\prime \prime} \mathrm{E}$; 20 Jun. 2020; M. Ng leg.; iNaturalist.org/observations/50287104 1 ठ

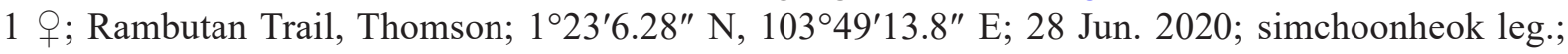
iNaturalist.org/observations/51206798 • 1 juvenile; Tengah; $1^{\circ} 21^{\prime} 58^{\prime \prime} \mathrm{N}, 103^{\circ} 43^{\prime} 47.2^{\prime \prime} \mathrm{E} ; 23 \mathrm{Jun} .2020$; C.W. Gan leg.; iNaturalist.org/observations/51352950 • 1 o ; Bishan; $1^{\circ} 20^{\prime} 57.1^{\prime \prime}$ N, 10349'59.8" E; 27 Jun. 2020; M. Finlay leg.; iNaturalist.org/observations/51885537 • 1 今ं; Bukit Timah Nature Reserve; $1^{\circ} 21^{\prime} 38.8^{\prime \prime} \mathrm{N}, 1^{\circ} 46^{\prime} 38.1^{\prime \prime} \mathrm{E} ; 5$ Jul. 2020; ramesh-birding-butterflying leg.; iNaturalist.org/observations/52003328 • 1 ô; Kent Ridge Park, Pasir Panjang; $1^{\circ} 17^{\prime} 7.28^{\prime \prime}$ N, 1034'28.3" E; 2 Jul. 2020; skm3355 leg.; iNaturalist.org/observations/52035813 • 1 \%; Bef Dairy Farm Road; $1^{\circ} 22^{\prime} 0^{\prime \prime}$ N, $103^{\circ} 46^{\prime} 32^{\prime \prime}$ E; 10 Jul. 2020; N. Sanjai leg.; iNaturalist.org/observations/52529111 • 1 ; Bukit Panjang; $1^{\circ} 21^{\prime} 50.8^{\prime \prime}$ N, 10346'34.2" E; 10 Jul. 2020; N. Sanjai leg.; iNaturalist.org/observations/52536392 • 1 क; Bef Old Upp Thomson Road; $1^{\circ} 23^{\prime} 12.3^{\prime \prime}$ N, $103^{\circ} 49^{\prime} 12.9^{\prime \prime}$ E; 10 Jul. 2020; Y.H. Koh leg.; iNaturalist.org/observations/52542825 • 1 §’; MacRitchie Reservoir; 
$1^{\circ} 20^{\prime} 41.3^{\prime \prime} \mathrm{N}, 103^{\circ} 49^{\prime 20.5}$ " E; 10 Jul. 2020; falseamoebae leg.; iNaturalist.org/observations/52574945 - 1 q; Novena; $1^{\circ} 20^{\prime} 0.598^{\prime \prime}$ N, 10349'39.3" E; 10 Jul. 2020; M. Finlay leg.; iNaturalist.org/observations/52644701 • 1 q; Upper Seletar Reservoir Park; 1 ${ }^{\circ} 23^{\prime} 58.7^{\prime \prime}$ N, 103²48'29.3" E; 10 Jul. 2020; K. Well leg.; iNaturalist.org/observations/52703749 • 1 juvenile; Bukit Panjang; $1^{\circ} 20^{\prime} 52.7^{\prime \prime}$ N, $103^{\circ} 46^{\prime} 30.3^{\prime \prime}$ E; 14 Jul. 2020; M. Nasry leg.; iNaturalist.org/observations/53034819 • 1 O; Rifle Range Link; $1^{\circ} 21^{\prime} 22.6^{\prime \prime} \mathrm{N}, 103^{\circ} 48^{\prime} 6^{\prime \prime} \mathrm{E}$; 12 Jul. 2020; K. Well leg.; iNaturalist.org/observations/53036305 • 1 O; 100 Dairy Farm Road, 679057; 1²1'42.7" N, 10346'31.1" E; 17 Jul. 2020; M. Ng leg.; iNaturalist.org/observations/53356890 • 1 क; 100 Dairy Farm Road, 679057; $1^{\circ} 21^{\prime} 42.7^{\prime \prime} \mathrm{N}, 103^{\circ} 46^{\prime} 31.1^{\prime \prime} \mathrm{E}$; 17 Jul. 2020; M. Ng leg.; iNaturalist.org/observations/53356981 • 1 ô; Central Water Catchment; $1^{\circ} 20^{\prime} 48.7^{\prime \prime} \mathrm{N}, 103^{\circ} 50^{\prime} 8^{\prime \prime}$ E; 12 Jul. 2020; M. Finlay leg.; iNaturalist.org/observations/53451611 • 1 ○; Central Water Catchment; $1^{\circ} 20^{\prime} 46.7^{\prime \prime} \mathrm{N}, 103^{\circ} 50^{\prime} 9.3^{\prime \prime} \mathrm{E}$; $12 \mathrm{Jul}$. 2020; M. Finlay leg.; iNaturalist.org/observations/53451612 • 1 o ; Bishan; $1^{\circ} 20^{\prime} 51.5^{\prime \prime} \mathrm{N}, 103^{\circ} 50^{\prime} 7.70^{\prime \prime} \mathrm{E} ; 12$ Jul. 2020; M. Finlay leg.; iNaturalist.org/observations/53452345 • 1 đ'; Novena; $1^{\circ} 20^{\prime} 8.13^{\prime \prime}$ N, $103^{\circ} 49^{\prime} 40.6^{\prime \prime}$ E; 18 Jul. 2020; M. Finlay leg.; iNaturalist.org/observations/53454664 • 1 q; Upper Thomson Road; $1^{\circ} 23^{\prime} 7.4^{\prime \prime} \mathrm{N}, 103^{\circ} 49^{\prime} 15.6^{\prime \prime}$ E; 19 Jul. 2020; M. Ng leg.; iNaturalist.org/observations/53596352 • 1 q; Wallace Centre, Dairy Farm Nature Park; 1²1'35.3" N, 10346'39" E; 19 Jul. 2020; K. Well leg.;

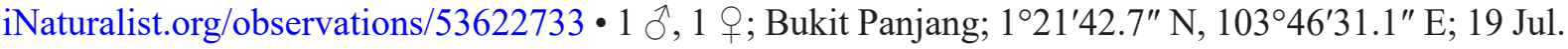
2020; lcwoo leg.; iNaturalist.org/observations/53668007 • 1 juvenile; Dairy Farm Nature Park; $1^{\circ} 21^{\prime} 42.7^{\prime \prime} \mathrm{N}, 1^{\circ}{ }^{\circ} 46^{\prime} 31.1^{\prime \prime} \mathrm{E}$; 19 Jul. 2020; lcwoo leg.; iNaturalist.org/observations/53673593 • 1 ○;;

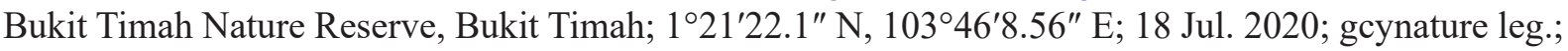
iNaturalist.org/observations/53775496 • 1 o $^{\top} ; 1^{\circ} 22^{\prime} 22.5^{\prime \prime} \mathrm{N}, 103^{\circ} 49^{\prime} 26.6^{\prime \prime} \mathrm{E}$; 24 Jul. 2020; noahartpradid leg.; iNaturalist.org/observations/54131093 • 1 juvenile; Windsor Park; $1^{\circ} 21^{\prime} 41.3^{\prime \prime} \mathrm{N}, 1^{\circ} 3^{\circ} 49^{\prime} 35.5^{\prime \prime} \mathrm{E}$;

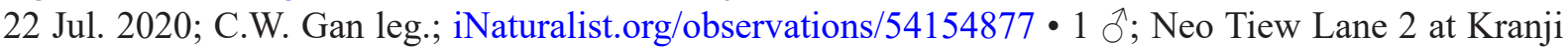
Marsh; $1^{\circ} 25^{\prime} 0.80^{\prime \prime} \mathrm{N}, 103^{\circ} 43^{\prime} 34.2^{\prime \prime} \mathrm{E}$; $25 \mathrm{Jul} .2020$; K. Well leg.; iNaturalist.org/observations/54259065 - 1 क; Central Water Catchment; ${ }^{\circ} 22^{\prime} 26.3^{\prime \prime} \mathrm{N}, 1^{\circ} 3^{\circ} 49^{\prime} 13.6^{\prime \prime} \mathrm{E}$; 26 Jul. 2020; gracelsy leg.; iNaturalist.org/observations/54379190 • 1 o $^{\prime}$; Thomson Nature Park; $1^{\circ} 22^{\prime} 56^{\prime \prime} \mathrm{N}, 103^{\circ} 49^{\prime} 19.5^{\prime \prime} \mathrm{E} ; 30 \mathrm{Jul}$. 2020; K. Well leg.; iNaturalist.org/observations/54847762 • 1 ô, 1 q; Thomson Nature Park; $1^{\circ} 23^{\prime \prime} 7.4^{\prime \prime} \mathrm{N}$, 10349'15.6" E; 31 Jul. 2020; S. Chan leg.; iNaturalist.org/observations/54945933 • 1 o'; Thomson Nature Park; 1²3'7.4" N, 10349'15.6" E; 31 Jul. 2020; S. Chan leg.; iNaturalist.org/observations/54946444 • 1 juvenile; Lorong Pelita, Thomson; ${ }^{\circ} 22^{\prime} 58.8^{\prime \prime}$ N, $103^{\circ} 49^{\prime} 17.3^{\prime \prime}$ E; 31 Jul. 2020; yeehwa leg.;

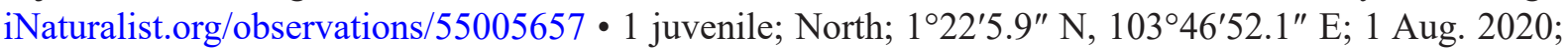
S.G. Wen leg.; iNaturalist.org/observations/55005954 • 1 đ, 1 \%; Central Water Catchment; $1^{\circ} 23^{\prime} 49.1^{\prime \prime} \mathrm{N}$, 10348'13" E; 2 Aug. 2020; S.K. Yung leg.; iNaturalist.org/observations/55122889 • 1 juvenile; Sungei Buloh Wetland Reserve; 1²6'46.2" N, 10343'39.7" E; 2 Aug. 2020; K. Well leg.; iNaturalist.org/observations/55167429 • 1 गे; Botanic Gardens, Holland Village; $1^{\circ} 18^{\prime} 28.8^{\prime \prime} \mathrm{N}$,

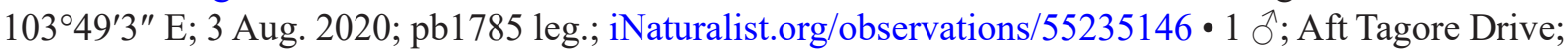
$1^{\circ} 23^{\prime} 5.78^{\prime \prime} \mathrm{N}, 103^{\circ} 49^{\prime} 14.9^{\prime \prime} \mathrm{E}$; 8 Aug. 2020; lcwoo leg.; iNaturalist.org/observations/55762965 • 1 juvenile; Bukit Drive, Bukit Timah; $1^{\circ} 20^{\prime} 54.5^{\prime \prime}$ N, 1034ㄴ $29.8^{\prime \prime}$ E; 2 Aug. 2020; gcynature leg.; iNaturalist.org/observations/56017697 • 1 ơ $^{\circ}$; Central Water Catchment; $1^{\circ} 20^{\prime} 44.7^{\prime \prime} \mathrm{N}, 103^{\circ} 50^{\prime} 10.1^{\prime \prime} \mathrm{E}$; 8 Aug. 2020; T.Z. Wan leg.; iNaturalist.org/observations/56103224 • 1 juvenile; Andrews Avenue, Sembawang; $1^{\circ} 27^{\prime} 26.8^{\prime \prime} \mathrm{N}, 103^{\circ} 50^{\prime} 21.1^{\prime \prime} \mathrm{E}$; 11 Aug. 2020; K. Well leg.; iNaturalist.org/observations/56116568 - 1 P; Mandai; $1^{\circ} 25^{\prime} 3.5^{\prime \prime}$ N, 10347'27.8" E; 16 Aug. 2020; S.K. Yung leg.; iNaturalist.org/observations/56602046 • 1 \%; Central Water Catchment; $1^{\circ} 23^{\prime} 50.7^{\prime \prime} \mathrm{N}, 1^{\circ} 03^{\circ} 48^{\prime} 20.3^{\prime \prime} \mathrm{E}$; 16 Aug. 2020; kangmin leg.; iNaturalist.org/observations/56625952 • 1 juvenile; Bukit Panjang; $1^{\circ} 21^{\prime} 2.5^{\prime \prime} \mathrm{N}, 103^{\circ} 46^{\prime} 44.2^{\prime \prime}$ E; 3 Aug. 2020; T.Z. Wan leg.; iNaturalist.org/observations/56827799 • 1 juvenile; Admiralty West Park Connector, Woodlands; $1^{\circ} 27^{\prime} 4.4^{\prime \prime} \mathrm{N}, 103^{\circ} 46^{\prime} 48^{\prime \prime}$ E; 18 Aug. 2020; M. Farook leg.; iNaturalist.org/observations/56946793 • 1 o ; Lower Peirce Reservoir; 1²2'12.3" N, 10349'23.1" E; 21 Aug. 2020; G. Lim leg.; iNaturalist.org/observations/57110204 • 1 क; Bukit Batok East Avenue 2, Bukit Batok Nature Park Playground; 1²0'59.3" N, 10345'49" E; 22 Aug. 2020; V. Lim leg.; iNaturalist.org/observations/57189865 • 1 juvenile; Bukit Batok; 1²0'58.6" N, 10345'51.6" E; 
TAN M.K. et al., Revision of Nisitrus (Orthoptera: Eneopterinae)

22 Aug. 2020; V. Lim leg.; iNaturalist.org/observations/57191688 • 1 ठ̊; Lim Chu Kang; $1^{\circ} 25^{\prime} 7.5^{\prime \prime}$ N, 10343'15.6" E; 23 Aug. 2020; S.K. Yung leg.; iNaturalist.org/observations/57315540 • 1 क; Lower Peirce Reservoir Park; 1 ${ }^{\circ} 22^{\prime} 23^{\prime \prime}$ N, 10349'26.8" E; 23 Aug. 2020; darkendaltrax leg.; iNaturalist.org/observations/57315659 • 1 क; Upper Seletar Reservoir Park; 1²4'3.20" N, 10348'25.3" E; 23 Aug. 2020; S. Chan leg.; iNaturalist.org/observations/57317179 • 1 juvenile; $1^{\circ} 20^{\prime} 46.7^{\prime \prime} \mathrm{N}$, 10353'9.63" E; 23 Aug. 2020; lowch leg.; iNaturalist.org/observations/57318298 • 1 क; Bukit Timah Nature Reserve; 1 ${ }^{\circ} 21^{\prime} 51.1^{\prime \prime}$ N, 10346'33.2" E; 24 Aug. 2020; noahartpradid leg.; iNaturalist.org/observations/57429535 • 1 ơ $^{\prime}$; Lower Peirce Reservoir; $1^{\circ} 22^{\prime} 12.3^{\prime \prime}$ N, $103^{\circ} 49^{\prime 2} 23.1^{\prime \prime}$ E; 29 Aug. 2020; G. Lim leg.; iNaturalist.org/observations/57916937 • 1 o ; Lim Chu Kang; 1 ${ }^{\circ} 25^{\prime} 1.2^{\prime \prime}$ N, $103^{\circ} 43^{\prime} 32.3^{\prime \prime}$ E; 3 Aug. 2020; S.K. Yung leg.; iNaturalist.org/observations/58007762 • 1 ô, 1 q; Upper Thomson Road; $1^{\circ} 23^{\prime} 7.4^{\prime \prime} \mathrm{N}, 103^{\circ} 49^{\prime} 15.6^{\prime \prime} \mathrm{E}$; 10 Jul. 2020; C. Tongleg.; iNaturalist.org/observations/58179315

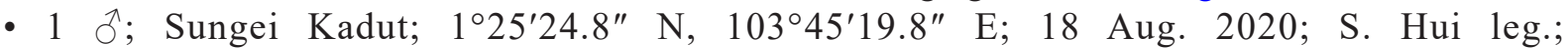
iNaturalist.org/observations/58230167 • 1 ऊ, 1 q; Champions Golf Course, Bukit Timah; $1^{\circ} 20^{\prime} 24.1^{\prime \prime} \mathrm{N}$, $103^{\circ} 47^{\prime} 54.6^{\prime \prime} \mathrm{E}$; 28 Aug. 2020; noahartpradid leg.; iNaturalist.org/observations/58407499 • 1 क; Ang Mo Kio; $1^{\circ} 22^{\prime} 52.5^{\prime \prime} \mathrm{N}, 103^{\circ} 49^{\prime} 16.8^{\prime \prime}$ E; 6 Sep. 2020; lowch leg.; iNaturalist.org/observations/58680372 • 1 juvenile; Zhenghua Park; $1^{\circ} 22^{\prime} 36.2^{\prime \prime} \mathrm{N}, 1^{\circ} 3^{\circ} 46^{\prime} 34.8^{\prime \prime}$ E; 6 Sep. 2020; S. Chan leg.;

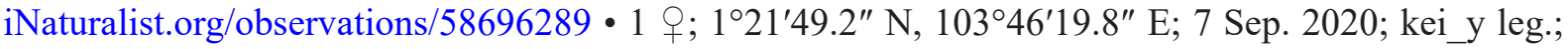

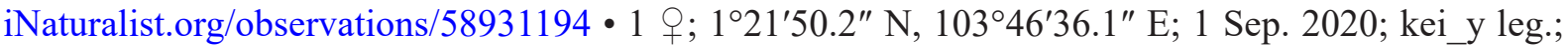
iNaturalist.org/observations/58931653 • 1 juvenile; Bef Mandai Road; $1^{\circ} 24^{\prime} 37.2^{\prime \prime}$ N, 103²4'41.8" E; 4 Sep. 2020; T.Z. Wan leg.; iNaturalist.org/observations/58957627 • 1 ภ, 1 \&; Dairy Farm Nature Park; $1^{\circ} 21^{\prime} 42.7^{\prime \prime}$ N, 10346'31.1" E; 9 Sep. 2020; S. Chan leg.; iNaturalist.org/observations/59036868 • 1 ;; Central Water Catchment; $1^{\circ} 22^{\prime} 16.5^{\prime \prime} \mathrm{N}, 1^{\circ} 3^{\circ} 46^{\prime} 46.2^{\prime \prime}$ E; 9 Sep. 2020; S. Chan leg.; iNaturalist.org/observations/59038833 - 1 juvenile; Upper Seletar Reservoir Park; 1 ${ }^{\circ} 24^{\prime} 3.20^{\prime \prime}$ N, 1034'ㄹ'25.3" E; 11 Sep. 2020; S. Chan leg.; iNaturalist.org/observations/59209460 • 1 q; Novena;

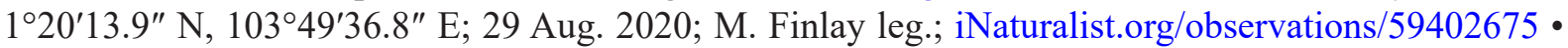
$1 \mathrm{O}^{\prime}$; Central Water Catchment; $1^{\circ} 23^{\prime} 47.7^{\prime \prime}$ N, $103^{\circ} 48^{\prime} 12.1^{\prime \prime}$ E; 13 Sep. 2020; S.K. Yung leg.; iNaturalist.org/observations/59419512 • 1 क; Central Water Catchment; $1^{\circ} 23^{\prime} 48.8^{\prime \prime} \mathrm{N}, 103^{\circ} 48^{\prime} 13.1^{\prime \prime} \mathrm{E}$; 13 Sep. 2020; S.K. Yung leg.; iNaturalist.org/observations/59419728 • 1 क ; $1^{\circ} 23^{\prime} 5.28^{\prime \prime}$ N, $103^{\circ} 49^{\prime} 21.3^{\prime \prime}$ E; 15 Sep. 2020; kei y leg.; iNaturalist.org/observations/59666269 • 1 गे; $1^{\circ} 22^{\prime} 56.7^{\prime \prime} \mathrm{N}, 103^{\circ} 49^{\prime} 16.8^{\prime \prime}$ E; 15 Sep. 2020; kei y leg.; iNaturalist.org/observations/59666275 • 1 q; Champions Golf Course, Bukit Timah; $1^{\circ} 20^{\prime} 28.3^{\prime \prime} \mathrm{N}, 103^{\circ} 47^{\prime} 53.7^{\prime \prime} \mathrm{E}$; 16 Sep. 2020; noahartpradid leg.; iNaturalist.org/observations/59759002 - 1 क; Bukit Panjang; $1^{\circ} 21^{\prime} 44.3^{\prime \prime} \mathrm{N}, 1^{\circ} 3^{\circ} 46^{\prime} 36.1^{\prime \prime}$ E; 20 Sep. 2020; M. Nasry leg.;

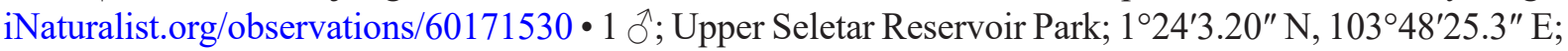
19 Sep. 2020; S. Chan leg.; iNaturalist.org/observations/60189103 • 1 q; Kranji Marshes, Neo Tiew Lane 2; $1^{\circ} 25^{\prime} 0.80^{\prime \prime} \mathrm{N}, 103^{\circ} 43^{\prime} 35.7^{\prime \prime}$ E; 20 Sep. 2020; mingwei leg.; iNaturalist.org/observations/60196972 • 1 q; $1^{\circ} 19^{\prime} 14.3^{\prime \prime} \mathrm{N}, 103^{\circ} 40^{\prime} 42.2^{\prime \prime} \mathrm{E}$; 20 Sep. 2020; prakashbr leg.; iNaturalist.org/observations/60402098 •

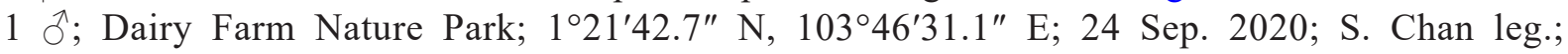

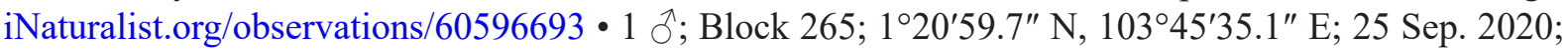
yq_1810 leg.; iNaturalist.org/observations/60696154 - 1 गे; Tanglin; $1^{\circ} 19^{\prime} 11.3^{\prime \prime} \mathrm{N}, 103^{\circ} 48^{\prime} 54.3^{\prime \prime} \mathrm{E}$; 26 Sep. 2020; scarlett26 leg.; iNaturalist.org/observations/60807200 • 1 juvenile; Bukit Panjang; $1^{\circ} 21^{\prime 2} 2.6^{\prime \prime}$ N, $103^{\circ} 46^{\prime} 56.7^{\prime \prime}$ E; 26 Sep. 2020; S. Chan leg.; iNaturalist.org/observations/60811750 • 1 O; Dairy Farm Nature Park; 1²1'42.7" N, 10346'31.1" E; 26 Sep. 2020; S. Chan leg.; iNaturalist.org/observations/60817045 • 1 juvenile; Bukit Panjang; 1²1'14.6" N, 10346'37" E; 27 Sep. 2020; S. Chan leg.; iNaturalist.org/observations/60972069 • 1 क; Thomson Nature Park; $1^{\circ} 23^{\prime} 7.5^{\prime \prime} \mathrm{N}$, $103^{\circ} 49^{\prime} 15.6^{\prime \prime}$ E; 1 Oct. 2020; G. Lim leg.; iNaturalist.org/observations/61387731 • 1 ô; Queenstown; $1^{\circ} 17^{\prime} 6.70^{\prime \prime} \mathrm{N}, 103^{\circ} 47^{\prime} 29^{\prime \prime}$ E; 6 Oct. 2020; S.K. Yung leg.; iNaturalist.org/observations/61843628 • 1 \%; Thomson Nature Park; 1²2'53.3" N, 10349'20.1" E; 4 Oct. 2020; patricialorenz leg.;

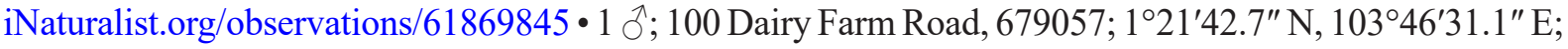
9 Oct. 2020; C. Tong leg.; iNaturalist.org/observations/62099010 • 1 O$^{\top}$; Tanglin, Swan Lake; $1^{\circ} 18^{\prime} 28.5^{\prime \prime} \mathrm{N}$, $103^{\circ} 48^{\prime} 55.2^{\prime \prime}$ E; 11 Oct. 2020; L.J. Yi leg.; iNaturalist.org/observations/62263904 • 1 ô, 1 q; Botanic 
Gardens; $1^{\circ} 18^{\prime} 49.7^{\prime \prime}$ N, $103^{\circ} 48^{\prime} 57.2^{\prime \prime}$ E; 11 Oct. 2020; lcwoo leg.; iNaturalist.org/observations/62384745 - 1 ठ̊; Holland Village; $1^{\circ} 19^{\prime} 50.5^{\prime \prime} \mathrm{N}, 103^{\circ} 46^{\prime} 52.7^{\prime \prime}$ E; 13 Oct. 2020; geledek leg.; iNaturalist.org/observations/62453318 • 1 juvenile; Unnamed Road; $1^{\circ} 26^{\prime} 31.8^{\prime \prime} \mathrm{N}, 103^{\circ} 44^{\prime} 9^{\prime \prime} \mathrm{E}$; 13 Oct. 2020; S.K. Yung leg.; iNaturalist.org/observations/62472505 • 1 o $^{\circ}$; Central Water Catchment; $1^{\circ} 22^{\prime} 24.8^{\prime \prime} \mathrm{N}$, $103^{\circ} 49^{\prime 2} 27.8^{\prime \prime}$ E; 16 Oct. 2020; Y. Jun leg.; iNaturalist.org/observations/62719526 • 1 o'; Yio Chu Kang; $1^{\circ} 24^{\prime} 7.06^{\prime \prime} \mathrm{N}, 103^{\circ} 49^{\prime} 4.78^{\prime \prime}$ E; 17 Oct. 2020; M. Ng leg.; iNaturalist.org/observations/62797963 • 1 \%; Central Water Catchment; $1^{\circ} 23^{\prime} 58.7^{\prime \prime}$ N, 10348'28.6" E; 18 Oct. 2020; S.K. Yung leg.; iNaturalist.org/observations/62877098 • 1 o'; HortPark; $1^{\circ} 16^{\prime} 43.5^{\prime \prime} \mathrm{N}, 103^{\circ} 48^{\prime} 6.56^{\prime \prime}$ E; 18 Oct. 2020; S. Chan leg.; iNaturalist.org/observations/62896486 • 1 q ; Kent Ridge Park; $1^{\circ} 17^{\prime} 2^{\prime \prime}$ N, 1034' $28.6^{\prime \prime}$ E; 18 Oct. 2020; S. Chan leg.; iNaturalist.org/observations/62898852 • 1 đ̊; Woodlands; $1^{\circ} 26^{\prime} 59.6^{\prime \prime} \mathrm{N}$, $103^{\circ} 46^{\prime} 43.2^{\prime \prime}$ E; 19 Oct. 2020; Y. Jun leg.; iNaturalist.org/observations/63007200 • 1 क; Holland Village; $1^{\circ} 19^{\prime} 49.8^{\prime \prime} \mathrm{N}, 103^{\circ} 46^{\prime} 53^{\prime \prime} \mathrm{E}$; 20 Oct. 2020; irwin88 leg.; iNaturalist.org/observations/63062077 • 1 \%; Holland Village; $1^{\circ} 20^{\prime} 2.78^{\prime \prime} \mathrm{N}, 1^{\circ} 3^{\circ} 46^{\prime} 53.7^{\prime \prime}$ E; 20 Oct. 2020; rocherussel leg.; iNaturalist.org/observations/63062082 • 1 o ; Holland Village; $1^{\circ} 19^{\prime} 50.3^{\prime \prime} \mathrm{N}, 103^{\circ} 46^{\prime} 52.8^{\prime \prime} \mathrm{E} ; 20$ Oct. 2020; khim99 leg.; iNaturalist.org/observations/63062122 • 1 q; Bukit Timah Road, Holland Village; $1^{\circ} 20^{\prime} 8^{\prime \prime} \mathrm{N}, 103^{\circ} 46^{\prime} 53.2^{\prime \prime} \mathrm{E}$; 20 Oct. 2020; i328026 leg.; iNaturalist.org/observations/63062126・1 O ; BukitTimah; $1^{\circ} 19^{\prime} 33.5^{\prime \prime} \mathrm{N}, 103^{\circ} 46^{\prime} 51.5^{\prime \prime} \mathrm{E} ; 20$ Oct.2020; kangmin leg.; iNaturalist.org/observations/63076249 - $1 \mathrm{O}^{\top}$; Central Water Catchment; $1^{\circ} 21^{\prime} 18.5^{\prime \prime} \mathrm{N}, 1^{\circ} 3^{\circ} 47^{\prime} 49.8^{\prime \prime}$ E; 23 Oct. 2020; C. Tong leg.; iNaturalist.org/observations/63332336 • 1 q; Central Water Catchment; $1^{\circ} 21^{\prime} 18.5^{\prime \prime} \mathrm{N}, 103^{\circ} 47^{\prime} 49.8^{\prime \prime} \mathrm{E}$; 23 Oct. 2020; C. Tong leg.; iNaturalist.org/observations/63332337 • 1 웅 Novena; $1^{\circ} 20^{\prime} 7.20^{\prime \prime} \mathrm{N}$, 1034'43.2" E; 22 Oct. 2020; M. Finlay leg.; iNaturalist.org/observations/63354764・1 §, 2 qo+; Novena; $1^{\circ} 20^{\prime} 7.78^{\prime \prime}$ N, $103^{\circ} 49^{\prime} 43.2^{\prime \prime}$ E; 22 Oct. 2020; M. Finlay leg.; iNaturalist.org/observations/63354765 - 1 O; Novena; $1^{\circ} 20^{\prime} 7.70^{\prime \prime} \mathrm{N}, 1^{\circ} 3^{\circ} 49^{\prime} 41.1^{\prime \prime}$ E; 18 Oct. 2020; M. Finlay leg.; iNaturalist.org/observations/63357376 • 1 o'; Novena; $1^{\circ} 20^{\prime} 8.8^{\prime \prime} \mathrm{N}, 103^{\circ} 49^{\prime} 44.2^{\prime \prime}$ E; 18 Oct. 2020; M. Finlay leg.; iNaturalist.org/observations/63357384 • 1 ò, 1 \% ; Central Water Catchment; $1^{\circ} 23^{\prime} 55.5^{\prime \prime} \mathrm{N}$, $103^{\circ} 46^{\prime} 40.1^{\prime \prime}$ E; 23 Oct. 2020; M. Finlay leg.; iNaturalist.org/observations/63371589 • 1 juvenile; Kent Ridge Park; $1^{\circ} 17^{\prime} 2^{\prime \prime}$ N, $103^{\circ} 47^{\prime} 28.6^{\prime \prime}$ E; 24 Oct. 2020; S. Chan leg.; iNaturalist.org/observations/63383652

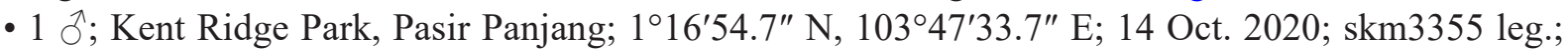
iNaturalist.org/observations/63400835 • 1 juvenile; Hindhede Nature Park; $1^{\circ} 20^{\prime} 56.1^{\prime \prime} \mathrm{N}, 103^{\circ} 46^{\prime} 32.6^{\prime \prime} \mathrm{E}$; 25 Oct. 2020; lcwoo leg.; iNaturalist.org/observations/63466017 • 1 đ; Aft W'Lands Waterfront Park; $1^{\circ} 27^{\prime 2} 2.89^{\prime \prime}$ N, $103^{\circ} 46^{\prime} 47^{\prime \prime}$ E; 29 Oct. 2020; S.G. Wen leg.; iNaturalist.org/observations/63750085 • 1?; Bukit Panjang; $1^{\circ} 21^{\prime} 37.7^{\prime \prime}$ N, 10346 $37.3^{\prime \prime}$ E; 30 Oct. 2020; M. Nasry leg.;

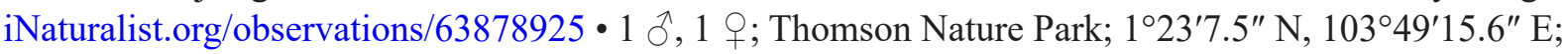
12 Jul. 2020; G. Lim leg.; iNaturalist.org/observations/52933922 • 1 ơ; Sungei Buloh Wetland Reserve; $1^{\circ} 26^{\prime} 53.1^{\prime \prime}$ N, 10343'28.5" E; 28 Dec. 2013; T.K. Hui leg.; iNaturalist.org/observations/19011702.

\section{Description}

Habitus similar to $N$. vittatus (Figs 7E, 23A-D): vertex black with cream-coloured margin around eyes (Fig. 11F). Fastigium velvety black with cream-coloured margins. Scapes dark red brown to black (particularly on dorso-inner margins). Antennae black with wide whitish rings. Frons and mouthparts most often yellow with a few dark spots (Fig. 10F). Maxillary palpi cream-coloured, apical segment black apically. Head lateral side yellow, with a wide black band posterior to eye (Fig. 12F). Pronotum covered with white setae; dorsal disk dark red brown to black (Fig. 11F); lateral lobes of pronotum dorsal third black, vivid yellow ventrally (cream-coloured in preserved specimens) (Fig. 12F). Legs dark orange brown. FIIIs brown, knees dark brown to black; TIIIs brown with black spines and spurs, dark brown to black near distal end; tarsomeres dark brown to black. Hindwings hyaline brown apically, transparent basally; longer than FWs, forming a dark brown tail exceeding FWs for more than twice the length of pronotum. Tergites red brown, with a pale band laterally; sternites pale, with a red brown median area. Cerci red brown, lighter dorsally. 
TAN M.K. et al., Revision of Nisitrus (Orthoptera: Eneopterinae)
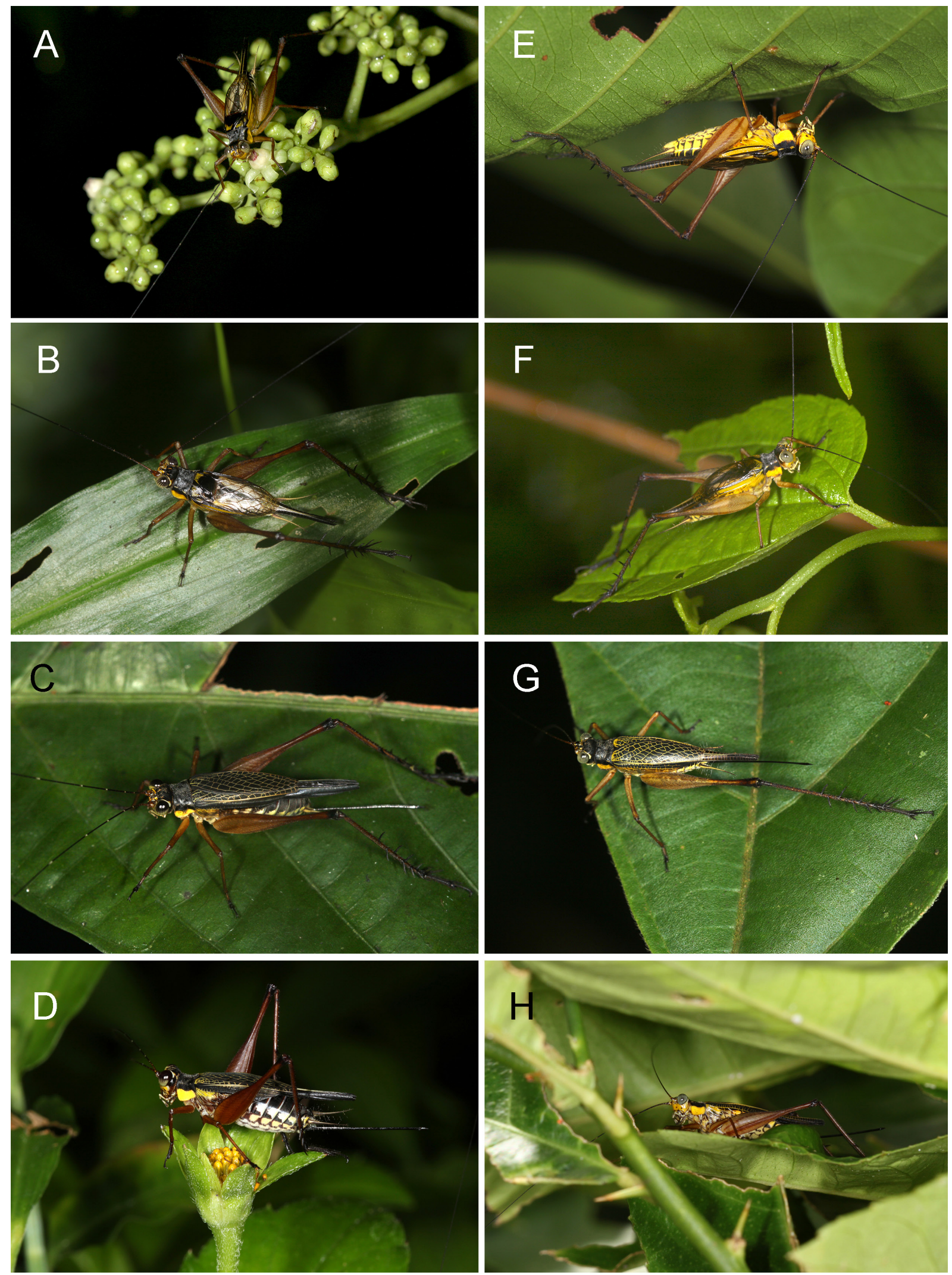

Fig. 23. A-D. Nisitrus malaya Robillard \& Tan sp. nov. E-H. N. vittatus (Haan, 1844). Adult $\widehat{\partial} \widehat{\partial}$ (A-B, $\mathrm{E}-\mathrm{F})$ and $\circ$ + $(\mathrm{C}-\mathrm{D}, \mathrm{G}-\mathrm{H})$ in their natural environment. Photograph credit: Ming Kai Tan. 


\section{Male}

ForEWINGS. FW colouration (Fig. 13E): dorsal field cells mostly transparent, veins mostly dark brown to black. Basal FW area black (instead of cream-coloured or brown as in N. vittatus), with a relatively small cream-coloured patch basally. R black (instead of cream-coloured as in $N$. vittatus), Sc projections cream-coloured basally, black apically. Apex of dorsal field somewhat truncated. Lateral field dark. FW venation (Fig. 13E): 1A curved, slightly angulated. Harp slightly longer than wide, with 3 oblique veins, basal one bifurcated distally, distal one bifurcated basally. $\mathrm{c} 1$ long and wide, $\mathrm{c} 2$ diamond-shaped; mirror (d1) longer than wide, not rounded, generally separated into two parts by a distinct transverse vein, the posterior part nearly rectangular, shorter than anterior part. Cell $\mathrm{d} 2$ narrower than $\mathrm{d} 1$. Anal-most and middle chords narrow and nearly parallel; basal-most chord extending from basal half of middle chord. Apical field short and rounded, with 3 wide cell alignments posterior to mirror and a narrow apical alignment; veins cream-coloured. Lateral field with 5 projections of Sc. Epiproct black. Subgenital plate pale cream-coloured with median area and anterior and posterior margins black.

Genitalia. Very similar to $N$. vittatus (Fig. 16E) but differ by pseudepiphallus faintly less robust and broad, anterior margin more strongly concave. Rami more strongly curved.
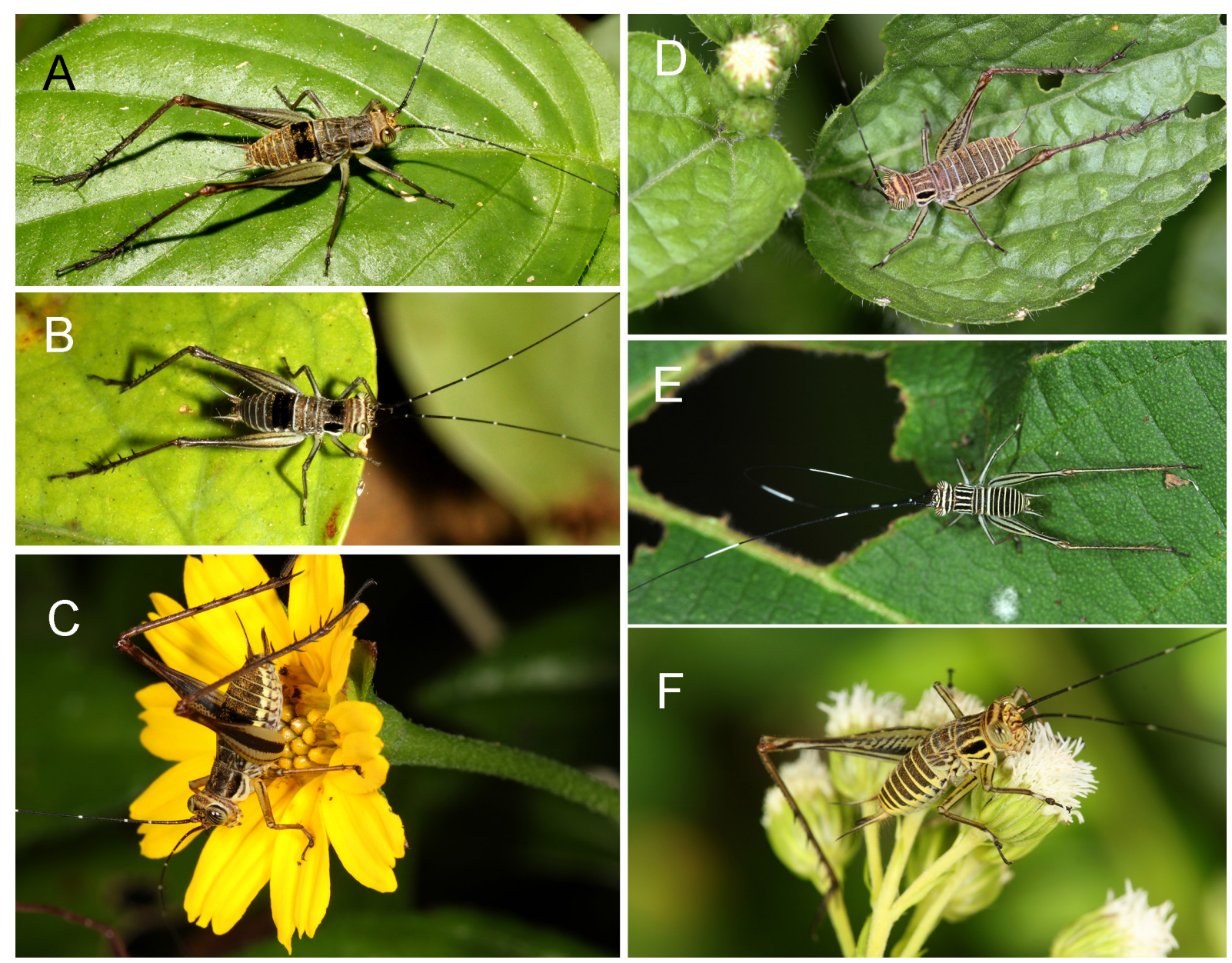

Fig. 24. Nymphs in their natural environment. A-C. Nisitrus malaya Robillard \& Tan sp. nov. D-F. N. vittatus (Haan, 1844). Photograph credit: Ming Kai Tan. 
TAN M.K. et al., Revision of Nisitrus (Orthoptera: Eneopterinae)

Table 8. Measurements of Nisitrus malaya Robillard \& Tan sp. nov. (in mm, means in brackets).

\begin{tabular}{|c|c|c|c|c|c|c|c|c|}
\hline & PronL & PronW & FWL & FWW & HWT & FIIIL & FIIIW & TIIIL \\
\hline Male holotype & 1.8 & 2.7 & 10.2 & 3.4 & 6.6 & 13.6 & 2.5 & 12.9 \\
\hline Males $(\mathrm{n}=5)$ & $\begin{array}{c}1.7-2.1 \\
(1.9)\end{array}$ & $\begin{array}{l}2.7-3.4 \\
\text { (3) }\end{array}$ & $\begin{array}{c}7.9-9.9 \\
(8.9)\end{array}$ & $\begin{array}{c}3.1-3.7 \\
(3.4)\end{array}$ & $\begin{array}{c}3.6-6.3 \\
(5.2)\end{array}$ & $\begin{array}{c}11.3-13.3 \\
(12.6)\end{array}$ & $\begin{array}{c}1.9-2.7 \\
(2.4)\end{array}$ & $\begin{array}{c}9.7-13.1 \\
(11.8)\end{array}$ \\
\hline \multirow[t]{3}{*}{ Females $(\mathrm{n}=5)$} & $\begin{array}{c}1.7-2.2 \\
(2.0)\end{array}$ & $\begin{array}{c}2.5-3.1 \\
(2.8)\end{array}$ & $\begin{array}{c}9.2-10.6 \\
(9.9)\end{array}$ & $\begin{array}{c}3.2-3.4 \\
(3.3)\end{array}$ & $\begin{array}{c}5.3-6.8 \\
(6.2)\end{array}$ & $\begin{array}{c}12.6-14.2 \\
(13.3)\end{array}$ & $\begin{array}{c}2.2-3.0 \\
(2.6)\end{array}$ & $\begin{array}{c}11.3-13.6 \\
(12.6)\end{array}$ \\
\hline & \multicolumn{4}{|c|}{ Dorsal spines of TIII } & & \multirow{2}{*}{\multicolumn{2}{|c|}{ OL }} & \\
\hline & Ias & Ibs & Oas & Obs & TaIIIs & & & \\
\hline Male holotype & 14 & 2 & 19 & $2-4$ & 2 & \multicolumn{2}{|c|}{-} & \\
\hline Males $(\mathrm{n}=5)$ & $\begin{array}{c}12-15 \\
(14)\end{array}$ & $2-3$ & $\begin{array}{c}19-21 \\
(20)\end{array}$ & $2-4$ & $2-3$ & \multicolumn{2}{|c|}{-} & \\
\hline Females $(n=5)$ & $13(13)$ & $1-3$ & $17(17)$ & $2-5$ & $2-3$ & \multicolumn{2}{|c|}{$\begin{array}{c}11.1-13.7 \\
(12.3)\end{array}$} & \\
\hline
\end{tabular}

\section{Female}

ForEWINGS. FW colouration (Fig. 14F): cells black, veins generally cream-coloured. Without distinct longitudinal white stripe around region of $\mathrm{CuA}, \mathrm{M}$ and $\mathrm{R}$ with distinct margin from black colouration on dorsal field; Sc projections cream-coloured basally, black apically. Lateral field dark. FW venation: 6-7 strong longitudinal veins on dorsal field; lateral field with 6 projections of Sc.

Genitalia. Ovipositor about as long as FIII. Copulatory papilla conical, small and stout; apex folded ventrally, short, pointed; dorsal face with a sclerotized area; ventro-anterior end forming a truncated lobule (Fig. 17J-K).

Juvenile (Fig. 24 A-C)

Differing from that of $N$. vittatus by darker colouration, usually grey, never as white as $N$. vittatus. Stripes on head similar to $N$. vittatus but sometimes very faint; pronotum dorsal disk homogeneously dark grey, without longitudinal stripes; sometimes with a large velvety black spot. Legs grey with dark stripes, but stripes not as distinct as in $N$. vittatus. Abdominal tergites dark grey, their posterior margins thinly lined with yellow, not forming a pattern of transverse stripes. In some individuals, first and second abdominal tergites with a particularly dark (black), velvety band.

\section{Measurements}

See Table 8.

\section{Ecology}

This species can be found among shrubs and herbaceous plants (but not grasses) (Fig. 27). The adults and nymphs from Singapore and Malaysia (previously reported as $N$. vittatus) have been reported to feed on the flower parts of a varieties of native (e.g., Dillenia suffruticosa (Griff.) Martelli) and exotic weedy (e.g., Lantana camara L.) plant species (Tan et al. 2017). They also feed on the foliages of understory plants such as Piper sarmentosum Roxb. (Fig. 27). In Singapore, N. malaya sp. nov. can be found abundantly in the understory where Piper sarmentosum dominates.

\section{Distribution}

Malay Peninsula (Singapore and Peninsular Malaysia [northern limit at the state of Penang]) (Fig. 5). 
Type locality

Singapore.

Calling song (Singapore, $\mathrm{n}=4$ males, 20 echemes; MNHN-SO-2851-2854) (Fig. 25A-C)

At $27.3^{\circ} \mathrm{C}$, the calling song consists of bouts of highly variable length, ranging from a few seconds to several minutes. Each bout is composed of short echemes made of triplets of syllables; echeme duration is $32.3 \pm 2.8 \mathrm{~ms}(29.0-37.56 \mathrm{~ms})$; echeme period is $64.5 \pm 4.3 \mathrm{~ms}(59.5-75.5 \mathrm{~ms})$; downtime between consecutive echemes is $32.1 \pm 4.4 \mathrm{~ms}(24.3-41.3 \mathrm{~ms})$. Durations for the first to third syllables of the triplet

N. malaya sp. nov.

A

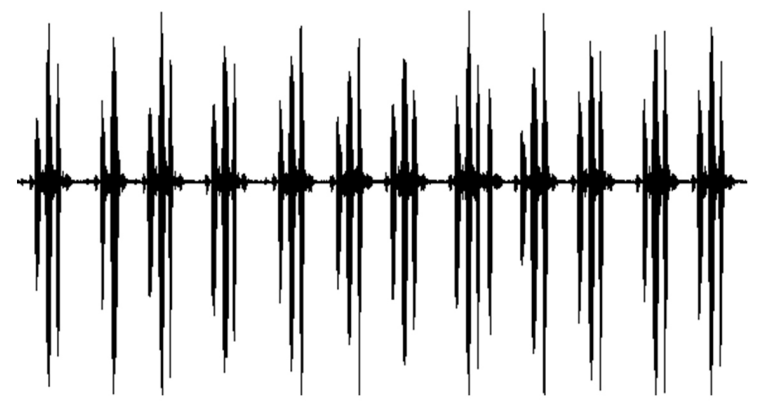

B

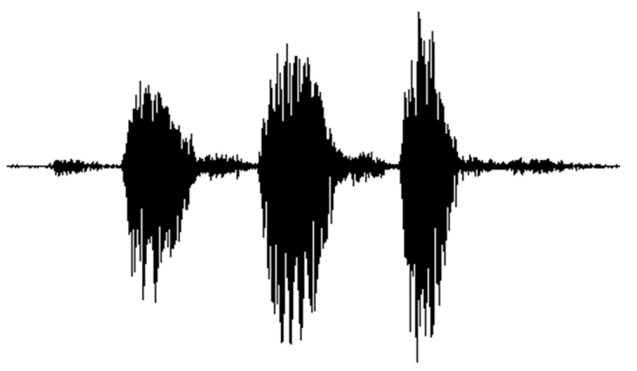

C

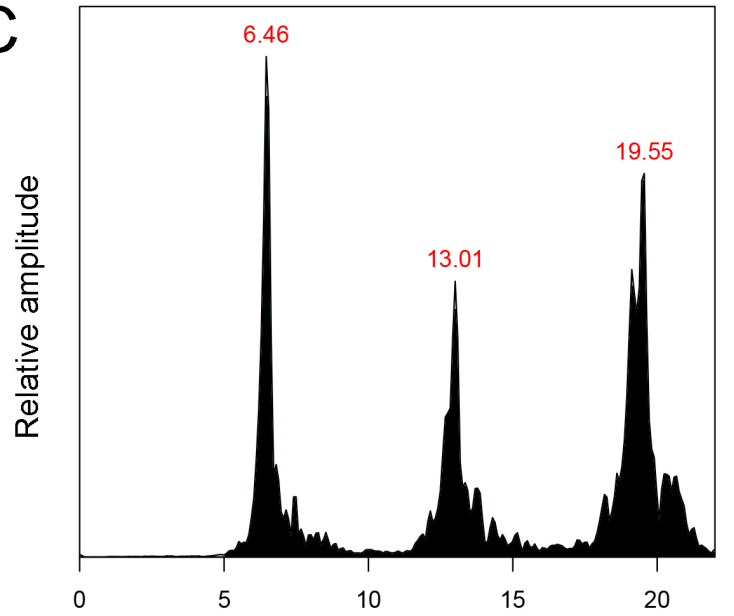

$\mathrm{D}$
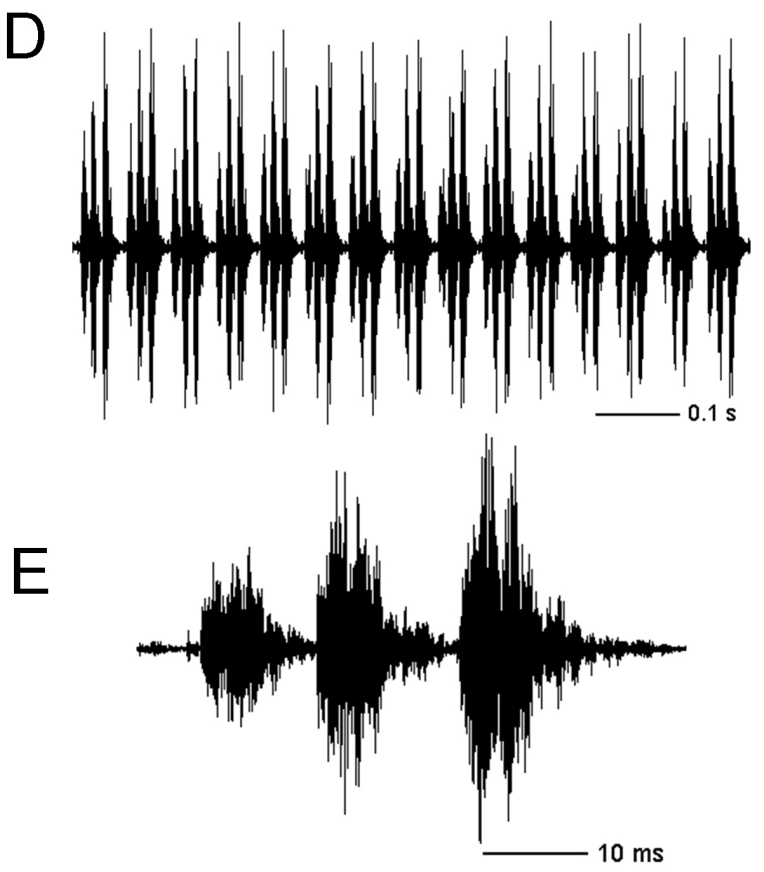

$\mathrm{F}$

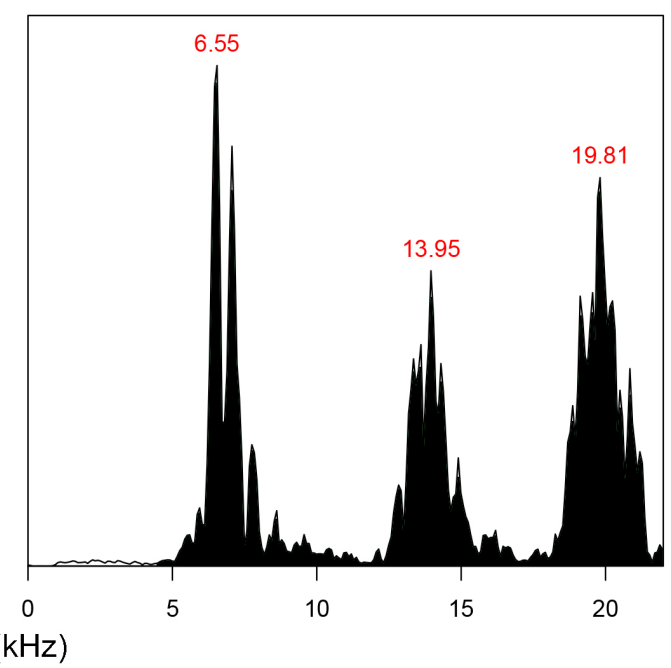

Fig. 25. Acoustics of Nisitrus malaya Robillard \& Tan sp. nov. (A-C) and N. vittatus (Haan, 1844) (D-F). A, D. Series of echemes. B, F. One echeme. C, F. Spectral plot of one echeme. 
are as follows: $6.1 \pm 1.5 \mathrm{~ms}(3.7-8.0 \mathrm{~ms}), 6.7 \pm 2.7 \mathrm{~ms}(2.5-10.6 \mathrm{~ms})$ and $5.8 \pm 2.9 \mathrm{~ms}(3.0-11.2 \mathrm{~ms})$. Call spectrum consists of a series of harmonics with three distinct peaks in the first three harmonics: first harmonic (fundamental frequency) at $7.35 \pm 1.28 \mathrm{kHz}(6.201-9.39 \mathrm{kHz})$, which is also the dominant frequency; second harmonic at $13.33 \pm 1.01 \mathrm{kHz}(12.23-15.07 \mathrm{kHz})$; third harmonic at $18.88 \pm 0.77 \mathrm{kHz}$ $(17.23-20.07 \mathrm{kHz})$.

\section{Remarks}

We split the species previously recognised as $N$. vittatus into two distinct species after integrating evidence from general and nymphal colouration, female genitalia morphology, acoustics, DNA (12S sequence) and distribution. In terms of adult morphology, the new species is very similar to N. vittatus in habitus, other than being darker in colouration. The male genitalia are not always distinguishable between these

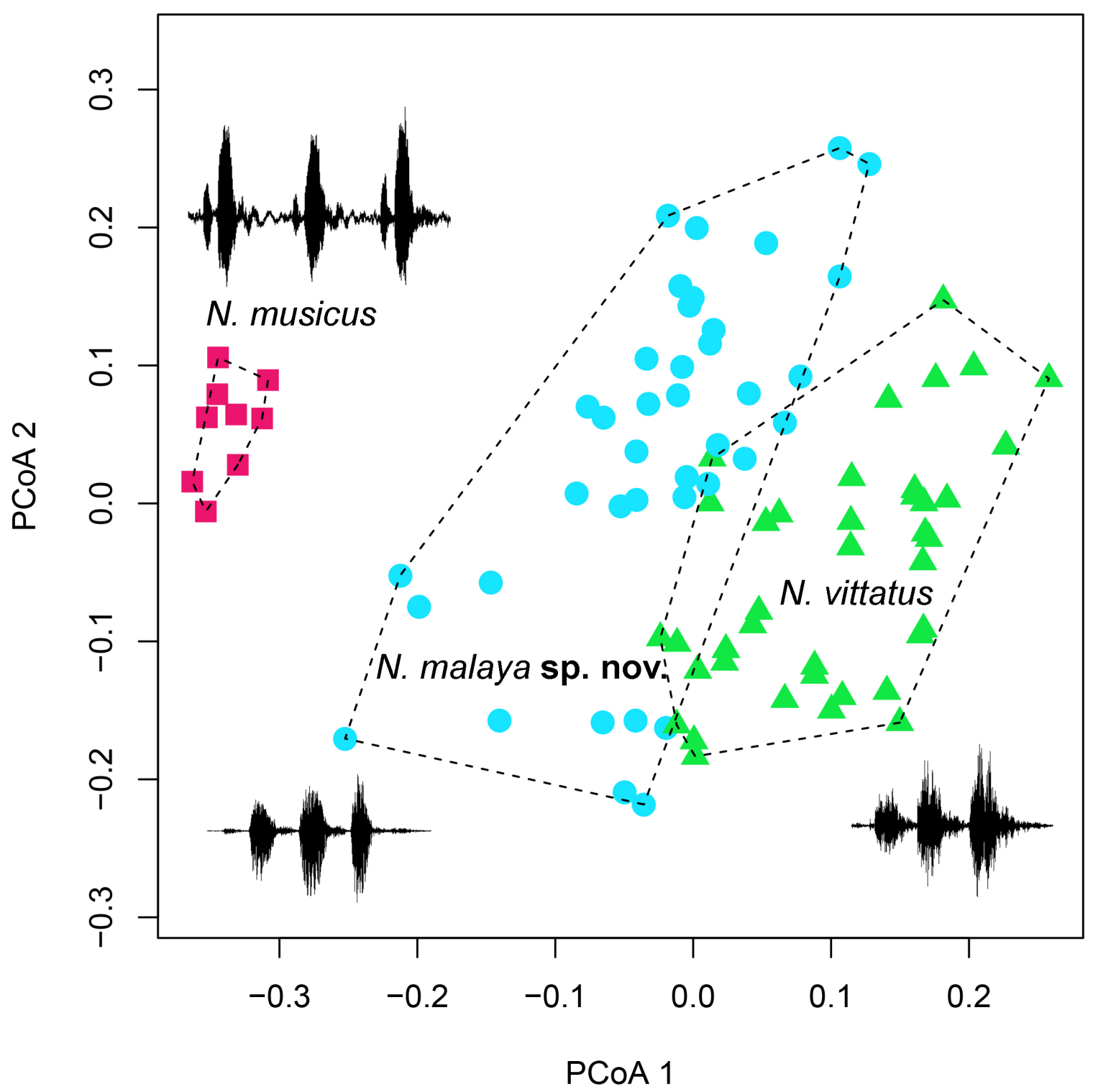

Fig. 26. Principal Coordinates Analysis (PCoA) of the acoustic properties of the calling songs of $N$. vittatus (Haan, 1844), N. malaya Robillard \& Tan sp. nov. and N. musicus Ingrisch, 1987. 


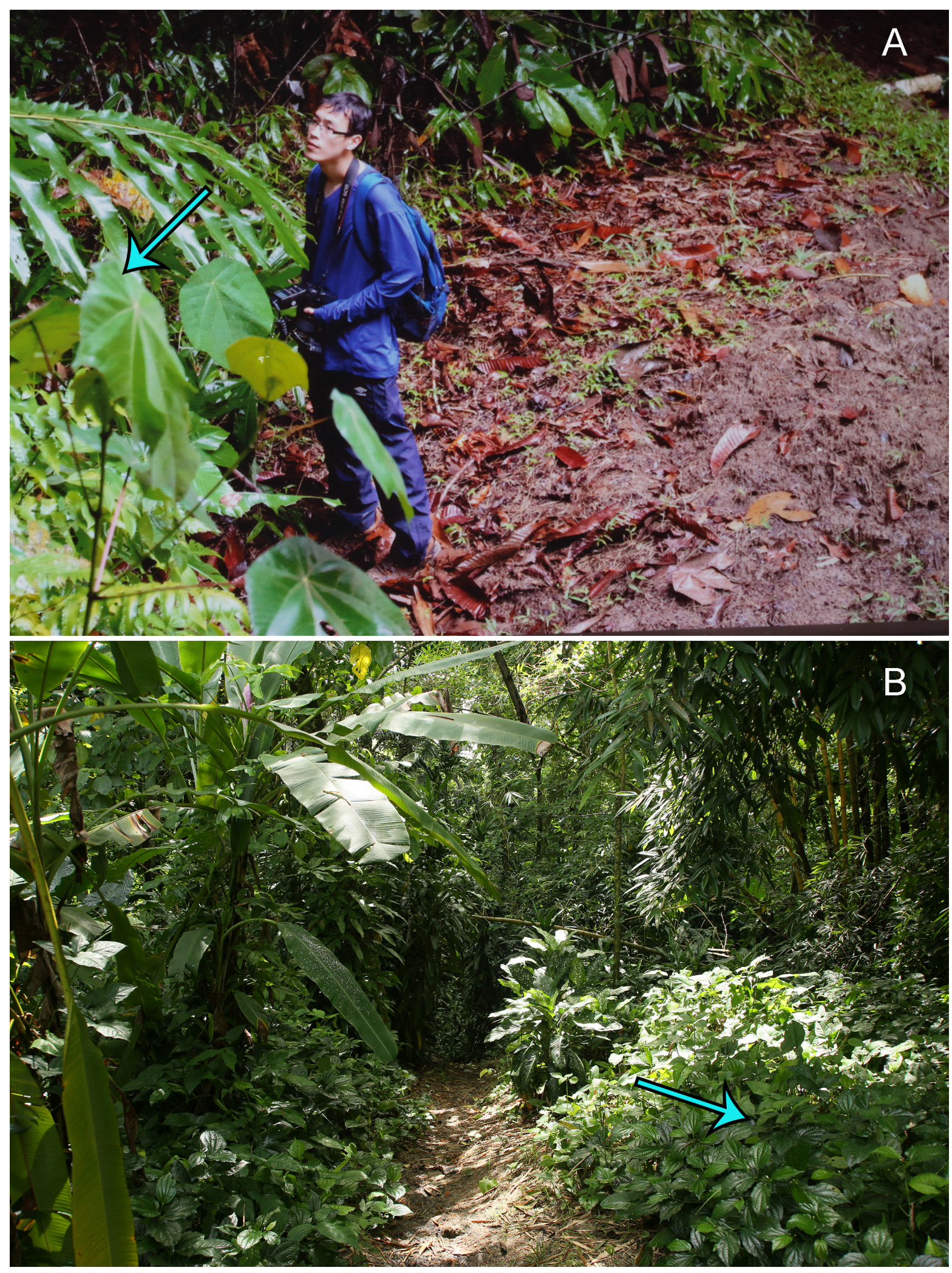

Fig. 27. A. Habitat where Nisitrus vittatus (Haan, 1844) can be found in Sungai Belalong in Brunei. B. Habitat where Nisitrus malaya Robillard \& Tan sp. nov. can be found in Singapore. The arrows point at the type of plants (Macaranga sp. in A, Piper sarmentosum Roxb. in B) on which Nisitrus can be found in relatively large numbers. Photograph credits: Yale-NUS students (A), Ming Kai Tan (B). 
species; but the sclerotization of the female genitalia can be differentiated. However, the colour patterns in the nymphs are drastically different. Likewise, a multivariate analysis of the call properties also showed distinct calling songs. The $12 \mathrm{~S}$ gene tree also demonstrates that the two species form distinct clades. Lastly, the new species occurs in Malay Peninsula whereas N. vittatus occurs in Borneo and Sumatra. Integrating these pieces of evidence indicates that $N$. vittatus and $N$. malaya sp. nov. are indeed separate species having probably diverged recently, despite the similarities in adult habitus and male genitalia.

Nisitrus maculosus (Walker, 1871) nomen dubium, new status

Table 2

Nisitra maculosa Walker 1871: 14.

Nisitra maculosa - Kirby 1906: 87.

Nisitrus maculosus - Chopard 1968: 353. - Cigliano et al. 2020 (Orthoptera Species File online).

\section{Type locality}

Indonesia: Maluka, Seram Island.

\section{Type details}

Male, not located.

\section{Remarks}

According to the uninformative original description, the type of the species is from Seram Island, while no species of Nisitrus has ever been recorded in the region of Maluku Archipelago (Indonesia). In addition, the description mentions that the eyes are little prominent, and that the FWs extend beyond the abdomen, which is not compatible with any other species of Nisitrus. With the type missing, we consider this species as nomen dubium (new status).

Nisitrus marginatus Walker, 1869 junior synonym of Nisitrus vittatus (Haan, 1944), syn. reinstated Table 2

Nisitra marginata Walker, 1869: 92.

Nisitrus vittatus - Saussure 1878: 653. - Chopard 1968: 352.

Nisitra vittata - Kirby 1906; 87 (junior synonym).

Nisitrus marginatus - Otte 1994: 67 (name reinstated). - Cigliano et al. 2020 (Orthoptera species File Online).

\section{Material examined}

Syntype

INDONESIA - Sumatra • 1 q; Stamford Raffles leg.; NHMUK 012497570.

\section{Remarks}

It is unclear why Otte (1994) reinstated $N$. marginatus as a valid species, even though earlier literature had already synonymised this species under $N$. vittatus. Based on the observation of a female syntype showing no difference with $N$. vittatus, we synonymise $N$. marginatus again under $N$. vittatus. 
Nisitrus musicus Ingrisch, 1987

Figs 5, 7F, 9B, 10G, 11G, 12G, 13F, 14G, 16F, 17L-M, 26, 28; Tables 1-2, 9

Nisitrus musicus Ingrisch, 1987: 178.

Nisitrus musicus - Tan et al. 2019: 303. — Cigliano et al. 2020 (Orthoptera Species File Online).

Diagnosis (revised from Ingrisch, 1987)

Frons whitish with a black stripe between eyes and black mouthparts; femora reddish brown with a black stripe dorsally; male genitalia with pseudepiphallus slenderer than in congeners. This species is most similar to $N$. danum sp. nov., also from Borneo, from which it differs by mouthparts black (instead of yellow), FIIIs black dorsally and female papilla. While this species is restricted to the highlands in the Kinabalu range, $N$. danum sp. nov. occurs in the Danum Valley and Tawau Hill areas at the east of Sabah. It is also similar to $N$. vittatus, $N$. crucius sp. nov. and $N$. malaya sp. nov., from which it differs by slightly larger and slenderer habitus, frons whitish with black front head and mouthparts, FIIIs with a black pattern dorsally, and slenderer pseudepiphallus.

\section{Material examined}

Holotype

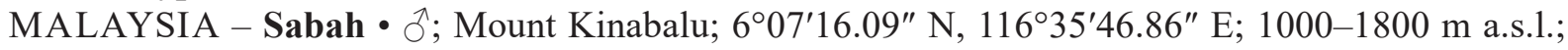
5-7 Aug. 1984; S. Ingrisch leg.; SMFD.

\section{Paratype}

MALAYSIA - Sabah • 1 ; same collection data as for holotype; SMFD.

\section{Additional specimens}

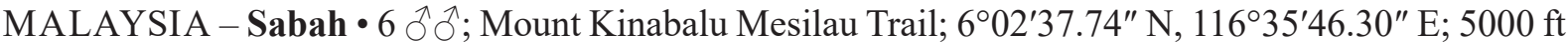
a.s.1.; 13-15 Mar. 1964; S. Kueh (Royal Society Expedition) leg.; NHMUK • 1 क; Mount Kinabalu Mesilau Trail; 602'37.74" N, 116 $35^{\circ} 46.30^{\prime \prime}$ E; 15 Feb. 1964; Royal Society Expedition leg.; NHMUK

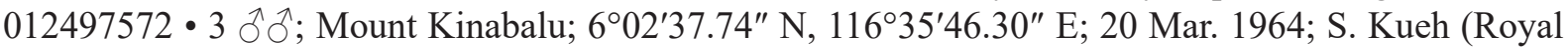
Society Expedition) leg.; NHMUK 1 ते; west of $3.1 \mathrm{~km}$ on Road Tenom Keningau, depleted lowland

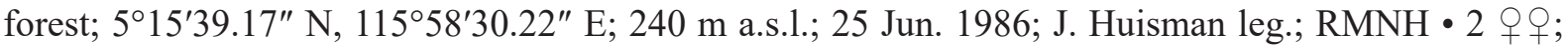
Tenompok 30 miles east of Jesselton; $6^{\circ} 00^{\prime} 10.40^{\prime \prime} \mathrm{N}, 116^{\circ} 31^{\prime} 45.20^{\prime \prime} \mathrm{E}$; $1460 \mathrm{~m}$ a.s.1.; 17-21 Oct. 1958;

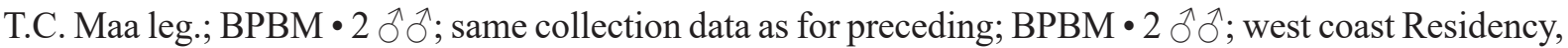

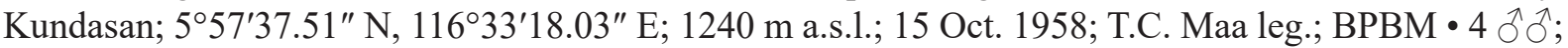
southern part of Kinabalu National Park; 5 59'50.78" N, 116 33'39.77" E; 1500-2000 m a.s.1.; 26 Apr.1 May 2013; A. Gorochov, M. Berezin, V. Gorochova and E. Tkatsheva leg.; PII: N52; ZIN • 3 q $ᄋ$;

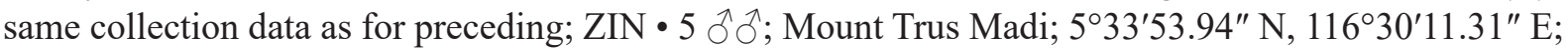
$\sim 1000$ m a.s.1.; 13-25 May 2007; A.V. Gorochov leg.; PIII: N37 Nmu3; ZIN • 2 9 ; same collection data as for preceding; ZIN • 2 ठิ $^{\wedge}$; Mount Kinabalu; $6^{\circ} 07^{\prime} 16.09^{\prime \prime} \mathrm{N}, 116^{\circ} 35^{\prime} 46.86^{\prime \prime} \mathrm{E}$; J. Zhang leg.; MNHN $\bullet 1$; same locality data as for preceding; Dec. 2018; J. Zhang leg.; PII: N48; MNHN-EOENSIF11070 • 3 우; same locality data as for preceding; J. Zhang leg.; MNHN • 2 q $q$; Tenompok near Kinabalu; $6^{\circ} 00^{\prime} 10.40^{\prime \prime}$ N, $116^{\circ} 31^{\prime} 45.20^{\prime \prime}$ E; $4500 \mathrm{ft}$ a.s.1.; 18 Mar. 1929; H.M. Pendlebury leg.; identified as Nisitra vittata by L. Chopard; MNHN-EO-ENSIF1738, MNHN-EO-ENSIF1743 • 1 O ; "Crocker Range National Park not far from Keningau Town, secondary-primary forest"; $5^{\circ} 28^{\prime} 07.79^{\prime \prime} \mathrm{N}$, 116²0'22.95" E; 1000-1300 m a.s.1.; 6 May 2013; A. Gorochov, M. Berezin, V. Gorochova and E. Tkatsheva leg.; N29-NboG2; ZIN • 1 क; Kinabalu Park, Ranau; 60'22.0" N, 116²32'33.5" E; 3 Aug. 2018; lhurteau leg.; iNaturalist.org/observations/15440494 • 1 क ; Ranau, Kinabalu Park World Heritage Site; $6^{\circ} 10^{\prime} 18.9^{\prime \prime} \mathrm{N}, 116^{\circ} 43^{\prime} 45.9^{\prime \prime} \mathrm{E}$; 10 Mar. 2018; rbeunen leg.; iNaturalist.org/observations/18843361 - 1 §̊; Kinabalu Park, Kota Belud; 6³'24.8" N, 116³3'58.7" E; 1 Aug. 2019; alvirginia leg.; 
iNaturalist.org/observations/30690023 • 1 क; Kota Belud District; 6 $6^{\circ} 49.0^{\prime \prime}$ N, 116 $30^{\prime} 35.3^{\prime \prime}$ E; 28 Jun. 2019; paulsullivan25 leg.; iNaturalist.org/observations/27783166 • 1 juvenile; Tambunan; 5 45'11.5" N, 116 30'0.6" E; 24 Jun. 2019; paulsullivan25 leg.; iNaturalist.org/observations/28232546

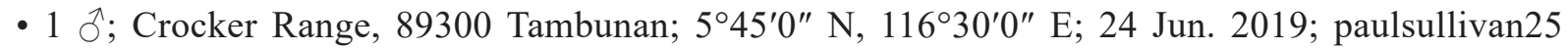
leg.; iNaturalist.org/observations/28232543 • 1 q; Tambunan; 545'10.9" N, 116 30'1.9" E; 24 Jun. 2019; paulsullivan25 leg.; iNaturalist.org/observations/28232551 • 1 juvenile; 89300 Ranau; $6^{\circ} 12^{\prime} 26.5^{\prime \prime} \mathrm{N}, 116^{\circ} 38^{\prime 2} 27.2^{\prime \prime}$ E; 2 Aug. 2019; a1virginia leg.; iNaturalist.org/observations/30808860

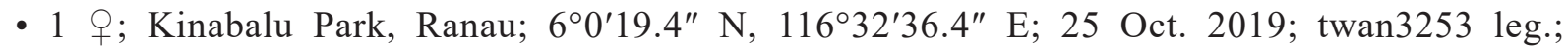
iNaturalist.org/observations/35365957 • 1 juvenile; Tambunan; 545'58.3" N, 116²0'32.9" E; 31 Dec. 2019; F. Jarvis leg.; iNaturalist.org/observations/37398325 • 1 गे; Kinabalu Park, Ranau; 60'31.1" N, 116³2'34.2" E; 23 Nov. 2016; K. O’Brien leg.; iNaturalist.org/observations/42450618 • around 20 individuals; Kinabalu Park, Ranau; 60'22.9" N, 116³2'38.6" E; 23 Nov. 2016; K. O’Brien leg.; iNaturalist.org/observations/42450617 • 2 우; Kundasang; 60'27.0" N, 116 32'1. 3" E; 1 Feb. 2017; V. Volkova leg.; iNaturalist.org/observations/51690441 • 1 क ; Kinabalu Park, Ranau; 6 ${ }^{\circ} 1^{\prime} 45.5^{\prime \prime}$ N, $116^{\circ} 32^{\prime} 49.1^{\prime \prime}$ E; 4 Jan. 2020; F. Jarvis leg.; iNaturalist.org/observations/37711505 • 1 + ; Ranau; 6 ${ }^{\circ} 1^{\prime} 36.8^{\prime \prime} \mathrm{N}$, 116³6'11.1" E; 4 Jul. 2020; M. Haffiszul Mohd Said leg.; iNaturalist.org/observations/51878361 - 1 क; Kinabalu Park, Ranau; 6¹'38.3" N, 116³6'11.2" E; 4 Jul. 2020; tanuki18 leg.; iNaturalist.org/observations/52011854 • 1 क; Kinabalu Park, Kota Belud; 6¹'36.7" N, 116³2'51.8" E; 13 Mar. 2019; D. Shaw leg.; iNaturalist.org/observations/23278330.

Additional description (after Ingrisch 1987)

\section{Male}

Genitalia (Fig. 16F). Pseudepiphallus very slender and elongated, distinctly longer than wide, anterior and anterior margins gently concave. Pseudepiphallic lophi slightly longer than wide (at base), subacute and slightly folded dorsally at apex, sclerotized laterally only, widely spaced apart from each other. Rami straight, swollen preapically, slightly diverging. Pseudepiphallic parameres narrow, diverging posteriorly, their basal sclerite short and narrow. Ectophallic lateral sclerites appearing rounded. Ectophallic apodemes straight and parallel. Endophallic sclerite elongated, its posterior lateral arms short.

\section{Female}

Genitalia. Copulatory papilla conical, smaller and stout; apex folded ventrally, elongated, pointed; dorsal face with a weakly sclerotized area; at ventro-anterior end a narrow oblong rim (Fig. 17L-M).

Juvenile (Fig. 28D-E)

Similar to adults in colour patterns, but younger instars differ by pronotal disk grey with dark longitudinal stripes, lateral lobes with a grey longitudinal stripe slightly ventral of the dorsal-third, sometimes in femora with white dorsal stripe, FIII with a white dorsal stripe at basal half. Legs darker in older instars, similar to adults.

\section{Measurements}

See Table 9.

\section{Ecology}

Adult and nymphal individuals have been observed to aggregate in large number ( 20 individuals) on the same plant (Fig. 28E).

\section{Distribution}

Borneo (Mount Kinabalu, Trus Madi, Tenompok, Tenom Keningau in Sabah) (Fig. 5). 


\section{Type locality}

Borneo: Sabah: Mount Kinabalu.
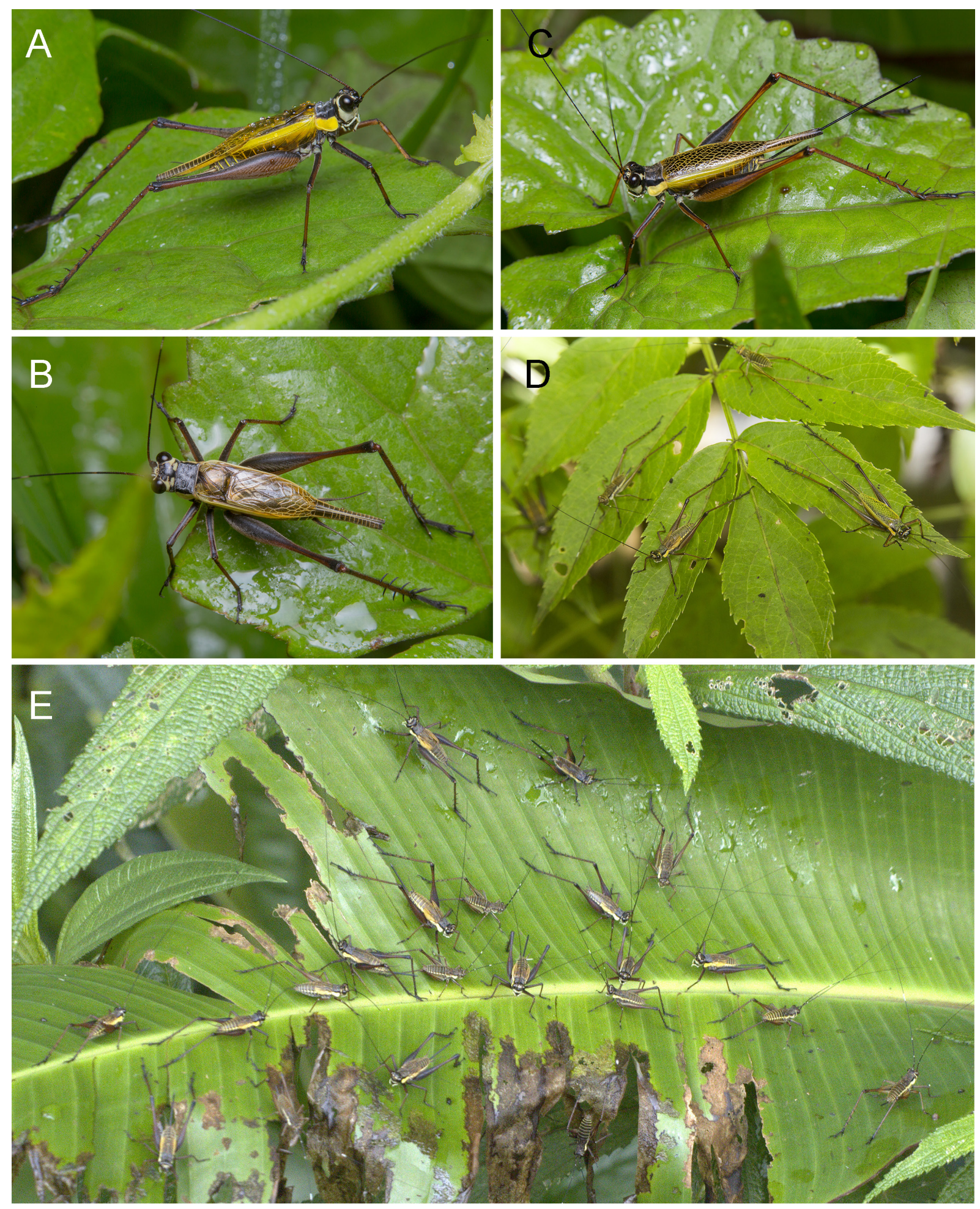

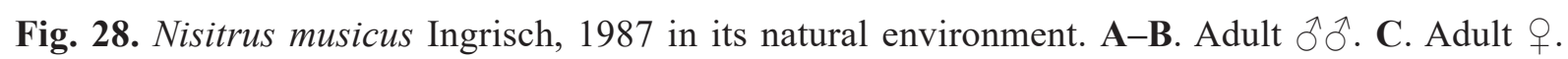
D-E. Aggregations of adults and nymphs. Photograph source and credits: iNaturalist; Marcus Ng (A-D), Kaitlyn O’Brien (E). 
TAN M.K. et al., Revision of Nisitrus (Orthoptera: Eneopterinae)

Table 9. Measurements of Nisitrus musicus Ingrisch, 1987 (in mm, means in brackets).

\begin{tabular}{|c|c|c|c|c|c|c|c|c|}
\hline & PronL & PronW & FWL & FWW & HWT & FIIIL & FIIIW & TIIIL \\
\hline Males $(n=5)$ & $\begin{array}{c}1.6-1.8 \\
(1.8)\end{array}$ & $\begin{array}{c}3.0-3.8 \\
(3.2)\end{array}$ & $\begin{array}{c}9.0-11.5 \\
(10.2)\end{array}$ & $\begin{array}{c}3.3-4.3 \\
(3.6)\end{array}$ & $\begin{array}{c}5.6-7.9 \\
(6.3)\end{array}$ & $\begin{array}{c}11.3-16.2 \\
(13.6)\end{array}$ & $\begin{array}{c}2.4-2.6 \\
(2.5)\end{array}$ & $\begin{array}{c}11.9-14.9 \\
(13.1)\end{array}$ \\
\hline \multirow[t]{3}{*}{ Females $(\mathrm{n}=5)$} & $\begin{array}{c}1.9-2.6 \\
(2.1)\end{array}$ & $\begin{array}{c}3.0-3.6 \\
(3.3)\end{array}$ & $\begin{array}{c}9.8-14.3 \\
(12.0)\end{array}$ & $\begin{array}{c}3.4-4.4 \\
(3.8)\end{array}$ & $\begin{array}{c}5.9-7.6 \\
(6.9)\end{array}$ & $\begin{array}{c}11.7-17.2 \\
(15)\end{array}$ & $\begin{array}{c}2.5-3.2 \\
(2.9)\end{array}$ & $\begin{array}{c}14.9-17.3 \\
(16)\end{array}$ \\
\hline & \multicolumn{4}{|c|}{ Dorsal spines of TIII } & & \multirow{2}{*}{\multicolumn{2}{|c|}{ OL }} & \\
\hline & Ias & Ibs & Oas & Obs & TaIIIs & & & \\
\hline Males $(\mathrm{n}=5)$ & $\begin{array}{c}11-13 \\
(12)\end{array}$ & $2-4$ & $\begin{array}{c}21-24 \\
(22)\end{array}$ & $2-7$ & $2-3$ & \multicolumn{2}{|c|}{-} & \\
\hline Females $(\mathrm{n}=5)$ & $\begin{array}{c}12-13 \\
(13)\end{array}$ & $2-4$ & $\begin{array}{c}20-23 \\
(21)\end{array}$ & $2-6$ & $2-3$ & \multicolumn{2}{|c|}{$\begin{array}{c}16.3-22.5 \\
(19.3)\end{array}$} & \\
\hline
\end{tabular}

Calling song ( $\mathrm{n}=1$ male, 9 echemes, MNHN-SO-2020-2857)

The calling song consists of long homogeneous bouts formed of very short echemes consisting of doublets of syllables; echeme duration is $29.7 \pm 1.1 \mathrm{~ms}(28.4-31.3 \mathrm{~ms})$; echeme period is $72.2 \pm 2.1 \mathrm{~ms}(69.8-$ $76.8 \mathrm{~ms}$ ); downtime between consecutive echemes is $42.5 \pm 2.2 \mathrm{~ms}(39.4-45.9 \mathrm{~ms})$. Duration for first and second syllables of the doublets are as follows: $7.5 \pm 0.6 \mathrm{~ms}(6.6-8.1 \mathrm{~ms})$ and $18.7 \pm 1.5 \mathrm{~ms}(15.8-20.5 \mathrm{~ms})$; with second syllable usually with greater amplitude than the first. The song spectrum consists of a series of harmonics, with two main peaks in the first two harmonics: first harmonic (fundamental frequency) which is also the dominant frequency peaks at $5.46 \pm 0.03(5.42-5.51) \mathrm{kHz}$; second harmonic peaking at $10.93 \pm 0.04(10.88-11.02) \mathrm{kHz}$.

Nisitrus rindu Robillard \& Tan sp. nov.

urn:1sid:zoobank.org:act:A3AE87F7-8196-4C9B-BDEF-8E9D21B92BE5

Figs $5,9 \mathrm{C}-\mathrm{D}, 10 \mathrm{H}, 11 \mathrm{H}, 12 \mathrm{H}, 14 \mathrm{H}, 17 \mathrm{~N}-\mathrm{O}$; Tables 2,10

Nisitrus brunnerianus - Robillard \& Desutter-Grandcolas 2004a: 276 (morphological phylogeny).

\section{Diagnosis}

This species differs from all known congeners by the combination of these characters: dorsum of head cream-coloured with a black band or T-shaped marking; frons completely black; pronotal lateral lobes yellow, their anterior ventral corner black. Female FW dorsal field with cells almost completely black; veins yellow; longitudinal veins on dorsal field with many more cross-veins, creating a net-like mosaic; lateral field with M, R cream-coloured. This species is similar to $N$. insignis by pattern on head dorsum, but differs by frons completely black (instead of yellow), unique pronotum colouration and female FW lateral field with $\mathrm{M}$ and $\mathrm{R}$ cream-coloured (instead of dark coloured). This species is also similar to $N$. brunnerianus, which probably occurs in sympatry, and $N$. hughtani sp. nov. by dark frons, but differs by the characteristic pattern on dorsum of head and pronotal lateral lobe, and by female FW lateral field hyaline in ventral half. It also differs from the sympatric $N$. vittatus and $N$. crucius sp. nov. by the black frons, pronotum lateral lobe and FW colouration.

\section{Etymology}

This species name refers to the word 'rindu', which means 'love' [verb] in Iban [a group of indigenous people from Borneo] language and 'home-sickness' = 'miss' [verb] in Bahasa Melayu (Malay language) 
and Indonesian. This new species is dedicated to the front-liners fighting against the COVID-19 pandemic who were far from their homes and loved ones during the early phase of the global pandemic (when the species' name was chosen).

\section{Material examined}

\section{Holotype}

MALAYSIA - Sarawak • +; Mount Murud; $6500 \mathrm{ft}$ a.s.1.; 354'28.44" N, 115²9'12.68" E; 15 Apr. 1979; identified as Nisitra brunneriana by L. Chopard; MNHN-EO-ENSIF10939.

\section{Paratypes}

INDONESIA - Kalimantan - 3 q; "West Borneo, Midden" [borders of Apokajan, Boeloengan and Beraoe]; $1^{\circ} 58^{\prime} 43^{\prime \prime}$ N, $116^{\circ} 6^{\prime} 43^{\prime \prime}$ E; 15-20 Oct. 1925; H.C. Siebers leg.; identified as Nisitrus brunnerianus by T. Robillard 2004; MNHN-EO-ENSIF10940 to ENSIF10942 • 1 क; Long Petak; $1^{\circ} 42^{\prime} 6^{\prime \prime} \mathrm{N}$, $116^{\circ} 12^{\prime 2} 5^{\prime \prime}$ E; 450 m a.s.1.; Sep. 1925; Brugs leg.; identified as Nisitrus brunnerianus by T. Robillard 2004; MNHN-EO-ENSIF10943.

MALAYSIA - Sabah • 1 क; near Long Pasia “Long Pa Sia”; 4²4’22.05" N, 115²43'40.97" E; 1020 m a.s.1.; 1-14 Apr. 1987; C. v. Achterberg leg.; RMNH • 1 क; same collection data as for preceding; PII: N57; RMNH. - Sarawak • 1 क; Mount Tibang; $1^{\circ} 39^{\prime}$ N, 114³4' E; 1700 m a.s.1.; E.G. Mjöberg leg.; MNHN-EO-ENSIF10944.

\section{Description}

Relatively large for the genus, colouration contrasted (Fig. 9C-D). Vertex cream-coloured with a variable longitudinal black band and one or two faint transverse black bands forming a T- or '+'-shaped black pattern (Fig. 11H). Scapes black, posterior end red brown. Antennae red brown with some segments black. Frons and face part of fastigium completely black, without yellow spots or bands (Fig. 10H). Mouthparts dark red brown to black. Maxillary palpi cream-coloured (Fig. 10H). Head lateral side black, sometimes with a small yellow spot at the ventro-posterior margin of eye (Fig. 12H). Pronotal disk generally black with lateral and posterior margins yellow (Fig. 11H); pronotal lateral lobe yellow, its ventro-anterior corner black (Fig. 12H). Legs red brown. FIIIs dark red brown, their inner basal area black; knees dark brown to black; TIIIs brown with black spines and spurs, dark brown to black near distal end; tarsomeres dark brown to black. Hindwings hyaline brown, with a longitudinal transparent window near external-basal area; longer than FWs, forming a dark brown tail exceeding FWs more than twice as long as pronotum. Abdomen generally black.

\section{Male}

Unknown.

\section{Female}

ForEWINGS. FW dorsal field with cells almost completely black; veins almost always yellow (Fig. 14H). Lateral field with $\mathrm{M}$ and R cream-coloured, sometimes with a cream-coloured patch at base; otherwise transparent or dark. FW venation: longitudinal veins on dorsal field with many cross-veins, creating a thin net-like mosaic.

Genitalia. Ovipositor distinctly longer than FIII; apex thin. Copulatory papilla conical, smaller and stout; apex folded ventrally, elongated, pointed; dorsal face with a sclerotized area; ventro-anterior end an oblong rim (Fig. 17N-O).

\section{Measurements}

See Table 10. 
TAN M.K. et al., Revision of Nisitrus (Orthoptera: Eneopterinae)

Table 10. Measurements of Nisitrus rindu Robillard \& Tan sp. nov. (in mm, means in brackets).

\begin{tabular}{|c|c|c|c|c|c|c|c|c|}
\hline & PronL & PronW & FWL & FWW & HWT & FIIIL & FIIIW & TIIIL \\
\hline Female holotype & 1.8 & 2.8 & 11.3 & 3.4 & 6.0 & 13.0 & 2.3 & 13.3 \\
\hline \multirow[t]{3}{*}{ Females $(\mathrm{n}=5)$} & $\begin{array}{c}1.8-2.2 \\
(2.0)\end{array}$ & $\begin{array}{c}2.8-3.7 \\
(3.1)\end{array}$ & $\begin{array}{c}11.3-13.5 \\
(12.5)\end{array}$ & $\begin{array}{c}3.4-4.3 \\
(3.8)\end{array}$ & $\begin{array}{c}5.8-7.5 \\
(6.7)\end{array}$ & $\begin{array}{c}13.0-16.4 \\
(15.2)\end{array}$ & $\begin{array}{c}2.3-3.1 \\
(2.8)\end{array}$ & $\begin{array}{c}13.3-17.5 \\
(15.5)\end{array}$ \\
\hline & \multicolumn{4}{|c|}{ Dorsal spines of TIII } & & \multirow{2}{*}{\multicolumn{2}{|c|}{ OL }} & \\
\hline & Ias & Ibs & Oas & Obs & TaIIIs & & & \\
\hline Female holotype & 17 & $3-5$ & 21 & $3-6$ & 3 & \multicolumn{2}{|c|}{17.3} & \\
\hline Females $(\mathrm{n}=5)$ & $\begin{array}{c}13-17 \\
(15)\end{array}$ & $3-5$ & $\begin{array}{c}21-24 \\
(23)\end{array}$ & $3-6$ & 3 & \multicolumn{2}{|c|}{$\begin{array}{c}17.1-21.2 \\
(18.9)\end{array}$} & \\
\hline
\end{tabular}

\section{Ecology}

Unknown.

\section{Distribution}

Borneo: Sabah, Sarawak and Kalimantan.

\section{Type locality}

Malaysia: Sabah.

\section{Calling song}

Unknown.

Nisitrus sumatrensis (Rehn, 1909) junior synonym of $\boldsymbol{N}$. insignis Saussure, 1878, syn. nov.

Table 2

Crystallomorpha sumatrensis Rehn, 1909: 209.

N. vittatus - Chopard 1968 12: 352.

Nisitrus sumatrensis - Otte 1994: 67. — Cigliano et al. 2020 (Orthoptera Species File online).

\section{Material examined}

\section{Holotype}

INDONESIA - Sumatra • ^̊; R. Weber leg.; AMNH.

\section{Type locality}

Indonesia: Sumatra.

\section{Remarks}

Based on the study of the type from Sumatra, we consider N. sumatrensis as a junior synonym of $N$. insignis, even though the colour pattern of the types of both species is slightly different. After the examination of the material from Sumatra identified "N. sumatrensis" and "N. insignis", we observed that the colour patterns form a continuum between a lighter version in $N$. insignis and the darker, more contrasting specimens previously identified as in the type of $N$. sumatrensis. There are also little diagnostic differences in the male and female genitalia for both series. 
Nisitrus vittatus (Haan, 1844)

Figs 1, 3, 5-6, 7G, 9E, 10I, 11I, 12I, 13G, 14I, 16G, 17P-Q, 23E-H, 24D-F, 25D-F, 26; Tables 1-2, 11

Gryllus (Platydactylus) vittatus Haan, 1844: 234.

Nisitra marginata Walker, 1869: 92. Synonym reinstated.

Nisitrus vittatus - Saussure 1878: 511, 653. — Chopard 1968: 352 (synonymised N. marginata). — Otte 1994: 67. — Robillard \& Desutter-Grandcolas 2004a: 276 (morphological phylogeny). — Robillard \& Tan 2013: 707 (redescription and neotype designation). - Tan et al. 2017: 146 (flower-visiting behaviour); 2019: 303. — Tan \& Wahab 2018: 126. — Cigliano et al. 2020 (Orthoptera Species File online).

Nisitra vittata - Kirby 1906: 87. — Chopard 1940: 199.

Nisitrus marginatus - Otte 1994: 67.

Nisitrus cf. vittatus - Vicente et al. 2017: 2203 (molecular phylogeny).

\section{Revised diagnosis}

Species of average size, colouration contrasting with black and yellow, characterised by black vertex, frons yellow, orange brown legs. Male area between $\mathrm{M}$ and $\mathrm{R}$ yellow, veins black or yellow; cells beneath $\mathrm{R}$ partly yellow, otherwise transparent. Anal-most and middle chords distinctly diverging apically, basalmost chord extend from midpoint/after midpoint of middle chord. Female copulatory papilla without truncated lobule at ventro-anterior end. Species very similar to $N$. malaya sp. nov., from which it differs by male genitalia with pseudepiphallus faintly less robust, narrower, anterior margin less concave; female copulatory papilla without truncated lobule at ventro-anterior end. Juvenile differs strikingly in colour patterns. Male calling song also differs by shorter echeme period.

\section{Material examined}

Neotype

INDONESIA - Sumatra • $0^{\Uparrow}$; Wai Lima, “Z. Sum.” [South Sumatra], Lampongs; 5²5'38.06" S, $105^{\circ} 01^{\prime 22.37 " ~ E ; ~ N o v .-D e c . ~ 1921 ; ~ K a r n y ~ a n d ~ S i e b e r s ~ l e g . ; ~ R M N H . ~}$

\section{Additional specimens}

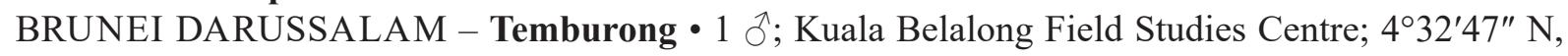
$115^{\circ} 9^{\prime 2} 7^{\prime \prime}$ E; 8 Jan. 2017; M.K. Tan leg.; KB.17.34; N37; MNHN-EO-ENSIF11069・ 1 \%; Kuala Belalong Field Studies Centre; 4³2'28.57" N, 11509'28.94" E; 23 Sep. 2016; M.K. Tan leg.; KB.16.10; UBDM • 1 q; Kuala Belalong Field Studies Centre; 4³2'28.57" N, 11509'28.94" E; 23 Sep. 2016; M.K. Tan leg.; KB.16.11; UBDM • 1 क; same locality data as for preceding; 25 Jul. 2017; M.K. Tan leg.; KB.17.53; UBDM • 1 juvenile; 4³2'49.2" N, 1159'20.3" E; 7 Jan. 2014; J. Hodecek leg.;

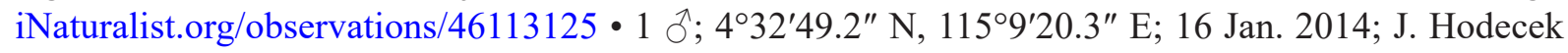
leg.; iNaturalist.org/observations/46113093.

INDONESIA - Sumatra 1 ó; same collection data as for neotype; Karny leg.; MNHN-ENSIF1742 - 1 \%; same collection data as for neotype; MNHN-EO-ENSIF3200 • 1 क; same collection data as for neotype; MNHN-ENSIF3198 • 1 \%; Pahoe; 22 Oct. [1925]; O. Posthumus leg.; MNHN-EOENSIF3199 • 1 क; same collection data as for preceding; MNHN • 1 क; S Sumatra, SW Lampongs, Mt Tanggaamues; $1^{\circ} 37^{\prime} 15.25^{\prime \prime}$ S, $103^{\circ} 36^{\prime} 23.79^{\prime \prime}$ E; 600 m a.s.1.; Dec. 1934; Giesting, Lieftinck and Toxopeus leg.; MNHN-EO-ENSIF3201 • 1 क; S Sumatra, Lalembang, Soeban Djerigi; 15 Jun. 1933; Soekarno leg.; MNHN-EO-ENSIF3202 • 1 O ; Damm[?] Muntok Banka; $2^{\circ} 03^{\prime} 16.62^{\prime \prime} \mathrm{S}, 105^{\circ} 10^{\prime} 43.11^{\prime \prime} \mathrm{E}$; 25 Nov. [19]23; MNHN-EO-ENSIF3203 • 1 O ; [Pidada] "Pedada-B Lampongs"; 5²7'42.68" S,

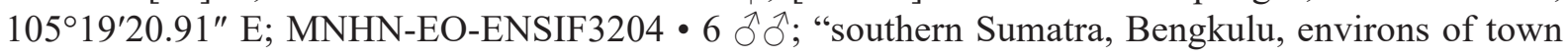
Curup (not far from city Bengkulu)"; 3²8-29' S, 102³1-38' E; 24 Apr.-2 May 2009; A. Gorochov, 
M. Berezin and E. Tkatsheva leg.; ZIN • 1 q; same collection data as for preceding; ZIN • 2 q ; "southern Sumatra, Lampung, National Park Way Kambas, 60 km NE of city Tanjung Karang, camp Way Kenam"; 5¹.678' S, 10546572' E; 20-30 m a.s.1.; 13-14 Apr. 2009; A. Gorochov, M. Berezin and

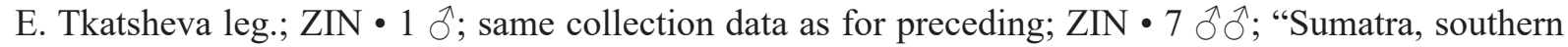
Sumatra, environs of village Banding Agung on Lake Ranau Danau”; 448.695' S, $103^{\circ} 55.289^{\prime}$ E; 600-700 m a.s.1.; 19-29 Apr. 2009; A. Gorochov, M. Berezin and E. Tkatsheva leg.; ZIN • 3 qo ; "Southern Sumtra, prov Lampung, National Park Way Kambas, $\sim 60 \mathrm{~km}$ NE of city Tanjung Karang, camp Way Kenam"; 5⒈678' S, 10546.572' E; 20-30 m a.s.1.; 13-14 Apr. 2009; A. Gorochov, M. Berezin and E. Tkatsheva leg.; PII N31; ZIN • 1 juvenile; "Sumatra, southern Sumatra, environs of village Banding Agung on Lake Ranau Danau"; 448.695' S, 10355.289' E; 600-700 m a.s.1.; 19-29 Apr. 2009; A. Gorochov, M. Berezin and E. Tkatsheva leg.; ZIN • 1 o; "southern Sumatra, Lampong, National Park Bukit Barisan Selatan, 15-20 km NW of town Krui, camp Kubu Prahu”; 54.341' S, 104³.093' E; $\sim 600$ m a.s.l.; 18-19 Apr. 2009; A. Gorochov, M. Berezin and E. Tkatsheva leg.; N33; ZIN. - Java •

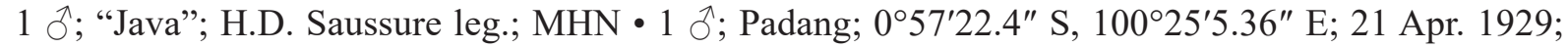

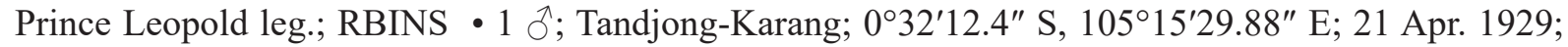
Prince Leopold leg.; RBINS • 1 q; Sungai Penuh City, Jambi; 207'53.7" S, 101¹5'53.8" E; 18 Jun. 2019; S. Wollney leg.; iNaturalist.org/observations/27481225 • 1 §ో; Pesawaran Regency, Lampung; 526'2.5" S, 1059'57.6" E; 9 Apr. 2019; J.-S. Wang leg.; iNaturalist.org/observations/36723277•

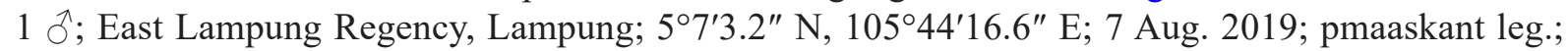
iNaturalist.org/observations/37027091 • 1 क; Sungai Penuh City, Jambi; 27'56.8" S, 101¹5'53.2" E; 20 Jun. 2019; S. Wollney leg.; iNaturalist.org/observations/27481235 • 1 +; Pesawaran Regency, Lampung; $5^{\circ} 26^{\prime} 4.5^{\prime \prime} \mathrm{S}, 105^{\circ} 10^{\prime 2} 29.3^{\prime \prime} \mathrm{E}$; 9 Apr. 2019; J.-S. Wang leg.; iNaturalist.org/observations/36723272 • 1 9; Eka Jaya, Kec. Jambi Sel., Kota Jambi, Jambi 36132; 1³7'1.2" S, 10340'16.8" E; 7 Aug. 2020; suhendra leg.; iNaturalist.org/observations/55695657 • 1 ○; Banyu Asin, Riau Silip, Bangka Regency, Bangka Belitung Islands; $1^{\circ} 53^{\prime} 3^{\prime \prime}$ S, $105^{\circ} 44^{\prime} 55^{\prime \prime}$ E; 20 Oct. 2020; R. Maharani leg.; iNaturalist.org/observations/63092557. - Kalimantan • 6 ô; "Marah"; 058'31.3" N, 116³3'14.8" E; 10-28 Nov. 1925; H.C. Siebers leg.;

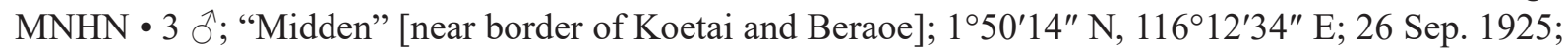
H.C. Siebers leg.; MNHN • $1 \delta^{\lambda}$; "Midden" [near border of Koetai and Beraoe]; $1^{\circ} 42^{\prime 2} 28^{\prime \prime}$ N, $116^{\circ} 15^{\prime} 40^{\prime \prime}$ E; 4 Aug. 1925; H.C. Siebers leg.; MNHN・1 ठ̊; "Midden"; 1925; H.C. Siebers leg.; MNHN1730 • 1 ð’; "Midden" [near border of Koetai and Beraoe]; $1^{\circ} 50^{\prime} 14^{\prime \prime}$ N, 116 $16^{\circ}$ '34" E; 27 Sep. 1925; H.C. Siebers

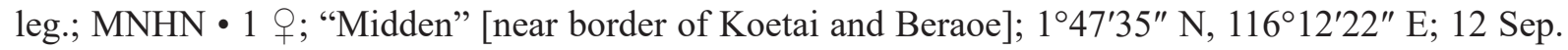
1925; H.C. Siebers leg.; MNHN • 1 juvenile; "Midden" [near border of Koetai and Beraoe]; $1^{\circ} 50^{\prime} 14^{\prime \prime}$ N, $116^{\circ} 12^{\prime} 34^{\prime \prime}$ E; 30 Sep. 1925; H.C. Siebers leg.; MNHN • 1 क; "Kac. Pujungan Kayan Mentarang Nat. Reserve, lowland dipterocarp forest, WWF station, Lalut Birai Base Camp"; $2^{\circ} 52^{\prime} \mathrm{N}, 115^{\circ} 49^{\prime} \mathrm{E} ; 355 \mathrm{~m}$ a.s.l.; Jun. 1993; D.C. Darling and U. Rosichon leg.; MZB • 1 o ; "Karimata Island Nat. Keptapang Res., primary rainforest, canopy cover"; $1^{\circ} 25^{\prime} \mathrm{N}, 106^{\circ} 40^{\prime}$ E; $350 \mathrm{~m}$ a.s.1.; Feb. 1991; Sutrisno Djenal leg.;

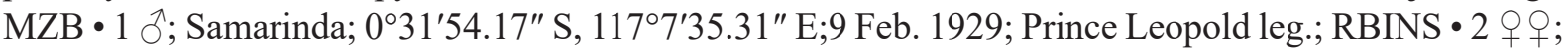

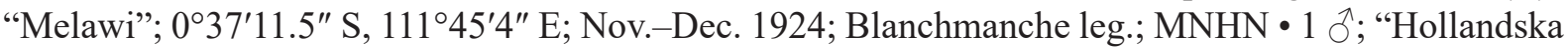

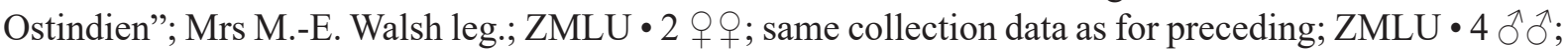
"Samarinda"; $0^{\circ} 28^{\prime} 59^{\prime \prime}$ S, 1178'33" E; Mrs M.-E. Walsh leg.; ZMLU • 3 q $q$; same collection data as for

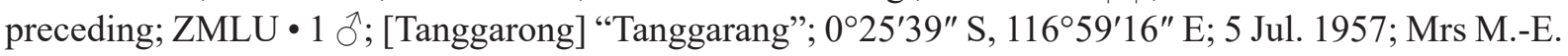
Walsh leg.; ZMLU • 1 đ; ; same locality data as for preceding; 4 Jul. 1957; Mrs M.-E. Walsh leg.; ZMLU •1 1 ; [ [Kaliorang] "Kariorang”; 052'29" N, 11756'31" E; Apr. 1937; Mrs M.-E. Walsh leg.; ZMLU.

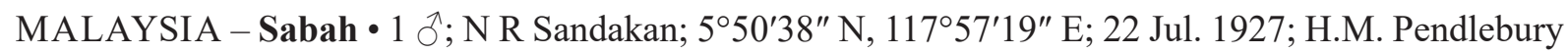

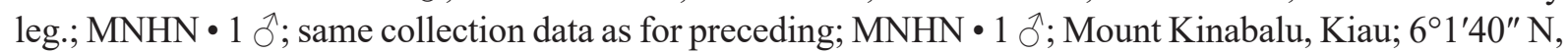
$116^{\circ} 29^{\prime} 26^{\prime \prime}$ E; 3000 ft a.s.1.; H.M. Pendlebury leg.; MNHN • 1 क; " "Crocker Range National Park not far

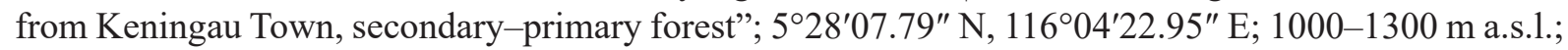
6 May 2013; A. Gorochov, M. Berezin, V. Gorochova and E. Tkatsheva leg.; N32-Nbo5; ZIN • 1 \%; "Mulu National Park, not far from borders with Brunei and Indonesia"; $4^{\circ} 01^{\prime} 58.72^{\prime \prime} \mathrm{N}, 114^{\circ} 49^{\prime} 00.56^{\prime \prime} \mathrm{E}$; 
100-300 m a.s.1.; 24-27 Mar. 2012; A.V. Gorochov, M. Berezin, E. Tkatsheva and I. Kamskov leg.; N27-

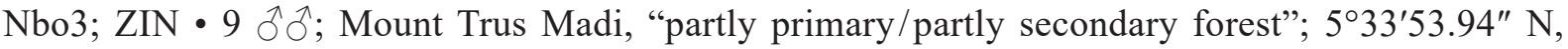
$116^{\circ} 30^{\prime} 11.31^{\prime \prime} \mathrm{E} ; \sim 1000 \mathrm{~m}$ a.s.1.; 13-25 May 2007; A.V. Gorochov leg.; ZIN • 10 우; Mount Trus Madi, "partly primary/partly secondary forest"; 533'53.94" N, 116 30'11.31" E; 1000 m a.s.1.; 13-25 May 2007; A.V. Gorochov leg.; ZIN • 1 今̃; "southern part of Kinabalu National Park, primary forest"; 559'50.78" N, 116³3'39.77" E; 1500-2000 m a.s.1.; 26 Apr.-1 May 2013; A. Gorochov, M. Berezin, V. Gorochova and E. Tkatsheva leg.; PII N25-Nbo1; ZIN • 1 ô; "Sandakan, environs of Sukau Village on Kinabatangan River ( $35 \mathrm{~km}$ from sea), secondary-primary forest"; $5^{\circ} 51^{\prime 2} 21.27^{\prime \prime} \mathrm{N}, 117^{\circ} 51^{\prime} 49.17^{\prime \prime} \mathrm{E}$; 0 m a.s.1.; 8-13 May 2013; A. Gorochov, M. Berezin and E. Tkatsheva leg.; PII N28-Nbo4; ZIN • 1 ठै; "Tawau Hills National Park near Tawau City, secondary-primary forest"; 4²3'55.38" N, 117 53'20.60" E; 200-400 m a.s.l.; 14-20 Apr. 2013; A.V. Gorochov, M. Berezin, E. Tkatsheva and I. Kamskov leg.; N26-

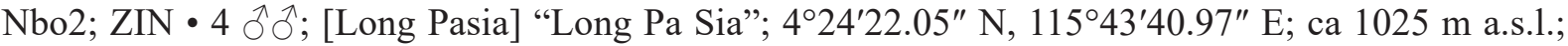
1-13 Apr. 1987; C. v. Achterberg leg.; RMNH • 2 우; same collection data as for preceding; RMNH • 2 우; Danum Valley Field Studies Centre; 45'ㄷ․ Achterberg leg.; RMNH 1 1 ; ; "West of $3.1 \mathrm{~km}$ on Road Tenom-Keningau Depleted lowland forest;

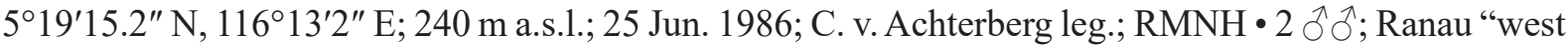
coast Residency, Ranau, 8 miles north Paring Hot Springs"; 5 50'47.95" N, 116 $44^{\circ} 02.41^{\prime \prime}$ E; $500 \mathrm{~m}$

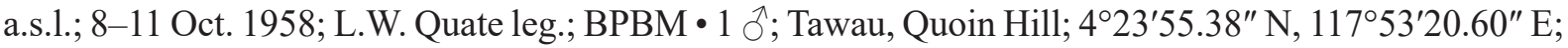
8-14 Jul. 1962; H. Holtmann leg.; BPBM • 1 §’; Sandakan "Sandakan Bay (NW), Sepilok Fore. Res."; $5^{\circ} 50^{\prime} 38^{\prime \prime} \mathrm{N}, 117^{\circ} 57^{\prime} 19^{\prime \prime} \mathrm{E}$; 1-10 m a.s.1.; 27 Oct 1957; J.L. Gressitt leg.; BPBM • 1 ơ; [Crocker Range National Park] "Croker Range n.p."; 5²8'07.79" N, 116 04'22.95" E; 11-17 Aug. 2003; "Whiting, Svenson, Bybee" leg.; PII: NviSA; MNHN-EO-ENSIF1709 • 2 o 0 ; same collection data as for preceding; MNHN • 1 juvenile; same collection data as for preceding; MNHN • 1 đ; "Sipitang", "Mendolong T3/

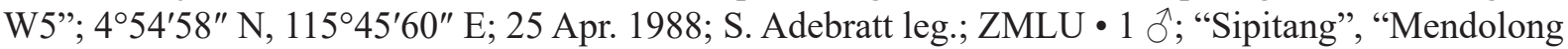
T1B/W4"; 454'58" N, 11545'60" E; 14 Mar. 1989; S. Adebratt leg.; ZMLU • 4 우; "Sipitang”,

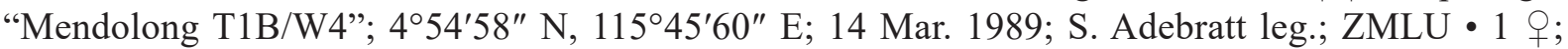
"Sipitang", "Mendolong T3/W5"; 454'58" N, 11545'60" E; 31 Mar. 1989; S. Adebratt leg.; ZMLU •

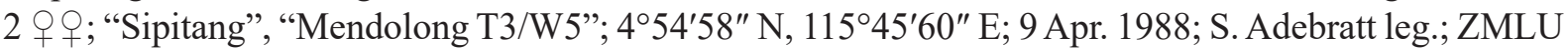
• 1 q; "Sipitang", "Mendolong T3/W5"; 454'58" N, 11545'60" E; 24 Feb. 1989; S. Adebratt leg.; ZMLU

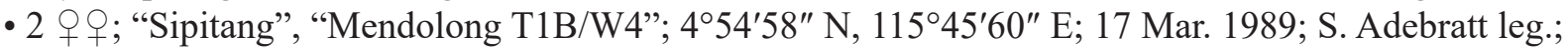
ZMLU • 7 o 우 ; "Sipitang”, "Mendolong T2B/W5”; 454'58" N, $115^{\circ} 45^{\prime} 60^{\prime \prime}$ E; 19 Apr. 1988; S. Adebratt

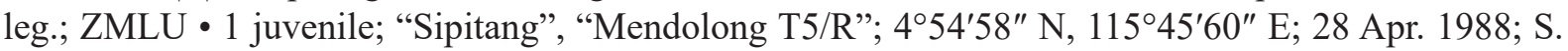

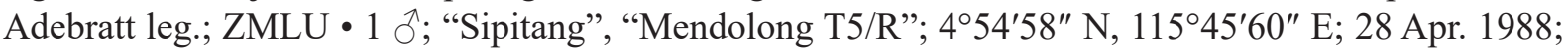
S. Adebratt; ZMLU • 1 juvenile; "Batu Niah 18.mbbbb"; $3^{\circ} 48^{\prime} 14^{\prime \prime}$ N, $113^{\circ} 45^{\prime} 15^{\prime \prime}$ E; Ulf Gärdenfors leg.;

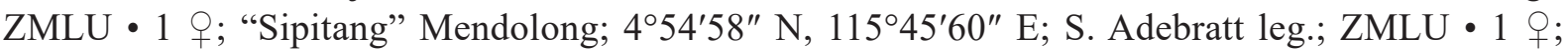
Kinabatangan; $5^{\circ} 29^{\prime} 33.2^{\prime \prime} \mathrm{N}, 118^{\circ} 12^{\prime} 23^{\prime \prime} \mathrm{E}$; 30 Jul. 2018; lhurteau leg.; iNaturalist.org/observations/15437369

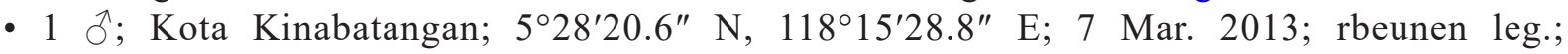
iNaturalist.org/observations/18843166 • 1 ơ; Jalan Poring, 89300 Ranau; 6²'36.6" N, 116 42'10.6" E; 6 Aug. 2013; doggy0406 leg.; iNaturalist.org/observations/24398754 • 1 ô; Lahad Datu District; $4^{\circ} 57^{\prime} 48.7^{\prime \prime}$ N, $117^{\circ} 40^{\prime} 20.3^{\prime \prime}$ E; 17 Oct. 2019; N.K. Thangasamy leg.; iNaturalist.org/observations/35226617

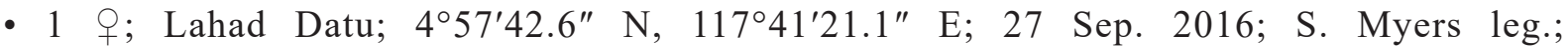
iNaturalist.org/observations/17100119 • $1 \mathrm{O}^{\lambda}$; Lahad Datu, Danum Valley Field Centre trails; $4^{\circ} 58^{\prime} 15.8^{\prime \prime} \mathrm{N}$, $117^{\circ} 48^{\prime} 8.63^{\prime \prime}$ E; 17 Jun. 2014; B. Crins leg.; iNaturalist.org/observations/40612983 • 1 §ో; Kinabatangan; $5^{\circ} 29^{\prime} 46.2^{\prime \prime}$ N, 118 16'39.7" E; 26 Sep. 2018; z_mcgrath leg.; iNaturalist.org/observations/27490441 •

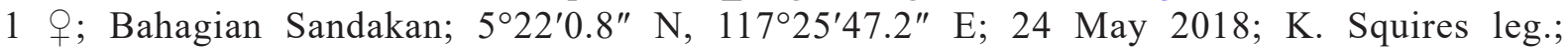
iNaturalist.org/observations/38619342 • 1 क; Penampang; 550'50.7" N, 1165'27.8" E; 28 Apr. 2020; tanuki18 leg.; iNaturalist.org/observations/44101645 - 1 juvenile; Penampang; $5^{\circ} 50^{\prime} 50.6^{\prime \prime} \mathrm{N}, 116^{\circ} 5^{\prime} 28^{\prime \prime} \mathrm{E}$; 23 May 2020; tanuki18 leg.; iNaturalist.org/observations/46949300 1 juvenile; Tuaran; 5 49'17.3" N, $116^{\circ} 20^{\prime} 28.8^{\prime \prime}$ E; 6 Jun. 2020; tanuki18 leg.; iNaturalist.org/observations/48631961 • 1 q; Tuaran;

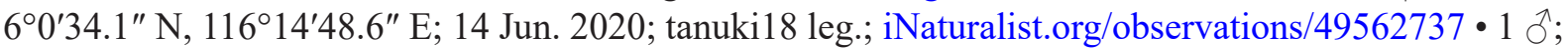


90000 Kinabatangan; 5²4'49.3" N, 118 $2^{\prime} 15.5^{\prime \prime}$ E; 7 Mar. 2020; M. de Groot leg.;

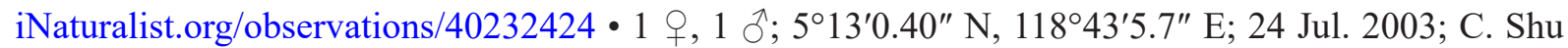
leg.; iNaturalist.org/observations/39450135. - Sarawak • 1 क ; Mount Dulit, moss forest; $3^{\circ} 19^{\prime} 58^{\prime \prime} \mathrm{N}$, $114^{\circ} 9^{\prime}$ E; $4000 \mathrm{ft}$ a.s.1.; 22 Oct. 1932; B.M. Hobby and A.W. Moore leg.; MNHN • 1 ð’; Batu Niah; $3^{\circ} 48^{\prime}$ N, $113^{\circ} 45^{\prime}$ E; 4-8 Mar. 1984; S. Ingrisch leg.; SMTD • 2 q; "Gunung Gading National Park, 80-90 km northwest of Kuching City"; 141'25.88" N, 10950'44.68" E; 100-300 m a.s.1.; 8-9 Mar. 2012; A. Gorochov, M. Berezin, E. Tkatsheva and I. Kamskov leg.; ZIN • 3 $\widehat{\jmath}$; "Kuching, environs of Kubah National Park, (situated on Matang Mountain and partly near it)"; $1^{\circ} 33^{\prime} 05.74^{\prime \prime}$ N, $110^{\circ} 18^{\prime} 54.26^{\prime \prime}$ E; 200-500 m a.s.l.; 10-17 Mar. 2012; A.V. Gorochov, M. Berezin, E. Tkatsheva and I. Kamskov leg.; PII: N24 Nku1; ZIN • 1 q; "Kuching, environs of Kubah National Park, (situated on Matang Mountain and partly near it)"; ${ }^{\circ} 33^{\prime} 05.74 "$ N, 110¹8'54.26" E; 200-500 m a.s.1.; 10-17 Mar. 2012; A.V. Gorochov, M. Berezin, E. Tkatsheva and I. Kamskov leg.; ZIN • $1{ }^{\Uparrow}$; Nanga Pelagus near Kapit; $1^{\circ} 42^{\prime} 03.32^{\prime \prime}$ N, $113^{\circ} 32^{\prime} 32.38^{\prime \prime}$ E; 180-585 m a.s.1.; 7-14 Oct. 1958; T. Maa leg.; BPBM • 1 đ̊; Kapit District, Merirai

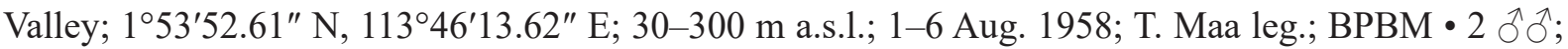
Tuba; 1 16'15" N, 111 5'13" E; 16-22 Jan. 1979; Gärdenfors, Hall, Hansson and Samuelsson leg.; ZMLU - 2 우; same collection data as for preceding; ZMLU • 1 q; "20 km SE Sebuyau, Tuba Forest clearing at longhouse"; $1^{\circ} 16^{\prime} 15^{\prime \prime} \mathrm{N}, 111^{\circ} 5^{\prime} 13^{\prime \prime}$ E; 15-22 Jan. 1979; Gärdenfors, Hall, Hansson and Samuelsson

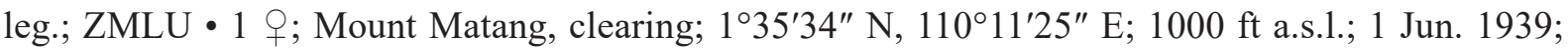
N.C.E. Miller leg.; NHMUK 012497573; • 1 q; Mount Dulit, moss forest; $3^{\circ} 19^{\prime} 58^{\prime \prime} \mathrm{N}, 114^{\circ} 9^{\prime} \mathrm{E} ; 4000 \mathrm{ft}$ a.s.1.; 22 Oct. 1932; B.M. Hobby and A.W. Moore leg.; NHMUK $012497571 \bullet 1$ ô; $1^{\circ} 45^{\prime} 24.8^{\prime \prime} \mathrm{N}$,

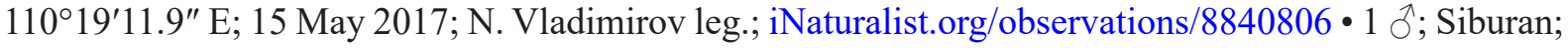
$1^{\circ} 7^{\prime} 19.3^{\prime \prime}$ N, $110^{\circ} 12^{\prime} 56.8^{\prime \prime}$ E; 21 Jun. 2013; flosker leg.; iNaturalist.org/observations/19469334 • 1 q; Bau; ${ }^{\circ} 22^{\prime} 52.2^{\prime \prime} \mathrm{N}, 110^{\circ} 13^{\prime} 15.3^{\prime \prime}$ E; 17 Sep. 2013; ml_ls leg.; iNaturalist.org/observations/28583992 •

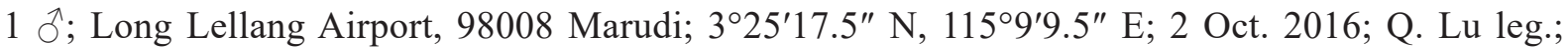
iNaturalist.org/observations/48562286 • 1 ô $^{\text {; }}$ Gunung Serapi Kuching, 93050, Petra Jaya, 93050 Kuching; $1^{\circ} 36^{\prime} 16.3^{\prime \prime} \mathrm{N}, 110^{\circ} 11^{\prime} 19.6^{\prime \prime} \mathrm{E}$; 19 Jul. 2019; plea84 leg.; iNaturalist.org/observations/29106017 • 1 q; Kuching; 1³4'33.2" N, 110¹7'54.1" E; 18 Jul. 2017; C. Shu leg.; iNaturalist.org/observations/39208711 - 1 O; Bahagian Miri; $3^{\circ} 25^{\prime} 16.8^{\prime \prime} \mathrm{N}, 115^{\circ} 9^{\prime} 15.8^{\prime \prime}$ E; 30 Sep. 2018; K. Lin leg.; iNaturalist.org/observations/20053192.

NO COUNTRY • 1 ภे; "South Borneo"; H. Fruhstorfer leg.; MHN • 1 O; "South Borneo"; H. Fruhstorfer

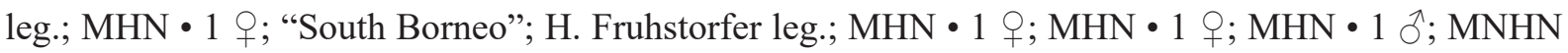

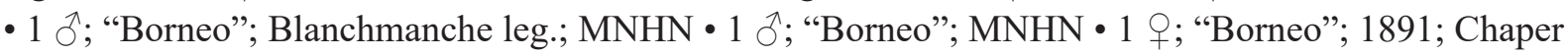

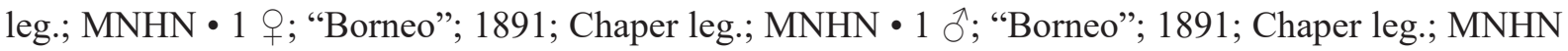
• 1 क ; "Borneo"; Bruner leg.; MNHN • 1 ठ̊’; "Borneo"; Bruner leg.; MNHN.

\section{Redescription}

Size average (Figs 2, 23E-H), similar to $N$. malaya sp. nov. but differs by slightly lighter colouration, male genitalia, female copulatory papilla and juvenile colouration.

\section{Male}

Genitalia (Fig. 16G). Pseudepiphallus relatively slender, slightly longer than broad, anterior margin straight, posterior margin indented in median area to faintly concave, lateral margins with basal half converge posteriorly, apical half somewhat parallel. Pseudepiphallic lophi slightly longer than wide (at base), sclerotized laterally only and covered with strong short setae; their apex slightly folded dorsally and sub-obtuse; moderately spaced apart from each other. Similar to N. malaya sp. nov. but differs by pseudepiphallus faintly more robust and broad, anterior margin more straight. Rami more straight. 
Female

Genitalia. Copulatory papilla conical, smaller and stout; apex folded ventrally, elongated, pointed; dorsal face with a sclerotized area; ventro-anterior end with an oblong rim, without truncated lobule (Fig. 17P-Q).

Juvenile (Fig. 24D-F)

Characterised by pale white or yellow colouration with numerous dark stripes all around body. Dorsum of head with three transverse black stripes that extends to gena. Eyes with numerous dark stripes. Fastigium with margin black; antennal black with pale rings; frons with a few black spots; palpal segments white with apices black. Pronotum with three thick, dark longitudinal stripes on dorsal disk, one very thick velvety black stripe between dorsal disk and lateral lobe; another curved stripe on lateral lobe ventral of the thick stripe; these stripes not reaching margins. Fore and middle legs with longitudinal dark stripes, two on each face, usually one dorsal and one ventral. FIII with longitudinal dark stripes, two dorsally, and two ventrally. Thoracic (excluding pronotum) and abdominal tergites typically dark or greyish, anterior margin dark, their posterior margin whitish forming a homogeneous light/dark striped pattern. Cerci whitish with a black stripe.

\section{Measurements}

See Table 11.

\section{Ecology}

This species can be found among shrubs and herbaceous plants (but not grasses) at the forest edge (Fig. 27A). Similar to N. malaya sp. nov., the adults and nymphs of this species have been observed in Brunei Darussalam to feed on the flower parts of a varieties of native and exotic plant species (Tan et al. 2017).

\section{Distribution}

Sumatra, Borneo.

\section{Type locality}

Indonesia: Sumatra: Lampongs, Wai Lima.

Calling song (Kuala Belalong, $\mathrm{n}=2$ males, 20 echemes; MNHN-SO-2020-2859 to MNHN-SO-2020-2860) (Fig. 25D-F)

At $27.0^{\circ} \mathrm{C}$, the calling song consists of long homogeneous bouts made of short echemes consisting of triplets of syllables; echeme duration is $32.47 \pm 3.79 \mathrm{~ms}(27.00-38.65 \mathrm{~ms})$; echeme period is $55.20 \pm 5.90 \mathrm{~ms}$ (50.52-74.27 ms); downtime between consecutive echemes is $22.73 \pm 7.26 \mathrm{~ms}(14.16-41.82 \mathrm{~ms})$. Durations for the first to third syllables of the triplet are as follows: $6.93 \pm 1.73 \mathrm{~ms}(4.57-9.95 \mathrm{~ms})$, $7.51 \pm 2.03 \mathrm{~ms}(4.80-11.67 \mathrm{~ms})$ and $7.22 \pm 2.82 \mathrm{~ms}(3.24-12.44 \mathrm{~ms})$. The call spectrum consists of a series of harmonics with three distinct peaks corresponding to the first three harmonics: first harmonic (fundamental frequency) at $6.86 \pm 0.28 \mathrm{kHz}(6.46-7.15 \mathrm{kHz})$, is usually the dominant frequency; second harmonic peaking at $14.08 \pm 0.39 \mathrm{kHz}(13.35-14.64 \mathrm{kHz})$; third harmonic peaking at $19.96 \pm 0.35 \mathrm{kHz}$ $(19.12-20.67 \mathrm{kHz})$.

\section{Remarks}

See N. malaya sp. nov. for arguments about considering two distinct species.

About synonymy of Nisitrus marginatus (Walker, 1869) under N. vittatus, considering that $N$. vittatus is variable in colouration and widely distributed in Borneo and Sumatra, and that the only known syntype 
TAN M.K. et al., Revision of Nisitrus (Orthoptera: Eneopterinae)

Table 11. Measurements of Nisitrus vittatus (Haan, 1844) in mm, means in brackets).

\begin{tabular}{|c|c|c|c|c|c|c|c|c|}
\hline & PronL & PronW & FWL & FWW & HWT & FIIIL & FIIIW & TIIIL \\
\hline Males $(\mathrm{n}=5)$ & $\begin{array}{c}1.6-2.5 \\
(1.9)\end{array}$ & $\begin{array}{c}2.6-3.2 \\
(2.8)\end{array}$ & $\begin{array}{c}8.6-10.4 \\
(9.4)\end{array}$ & $\begin{array}{c}2.9-3.9 \\
(3.5)\end{array}$ & $\begin{array}{c}5.1-6.8 \\
(5.8)\end{array}$ & $\begin{array}{c}9.9-12.6 \\
(11.4)\end{array}$ & $\begin{array}{c}1.9-2.5 \\
(2.3)\end{array}$ & $\begin{array}{c}10.0-12.3 \\
(11.5)\end{array}$ \\
\hline \multirow[t]{3}{*}{ Females $(\mathrm{n}=5)$} & $\begin{array}{c}1.8-2.3 \\
(2.0)\end{array}$ & $\begin{array}{c}2.9-3.3 \\
(3.1)\end{array}$ & $\begin{array}{c}10.7-11.8 \\
(11.3)\end{array}$ & $\begin{array}{c}3.1-3.7 \\
(3.3)\end{array}$ & $\begin{array}{c}5.7-7.0 \\
(6.1)\end{array}$ & $\begin{array}{c}12.7-14.9 \\
(13.8)\end{array}$ & $\begin{array}{c}2.1-3.0 \\
(2.6)\end{array}$ & $\begin{array}{c}12.7-14.3 \\
(13.3)\end{array}$ \\
\hline & \multicolumn{4}{|c|}{ Dorsal spines of TIII } & & \multirow{2}{*}{\multicolumn{2}{|c|}{ OL }} & \\
\hline & Ias & Ibs & Oas & Obs & TaIIIs & & & \\
\hline Males $(n=5)$ & $\begin{array}{l}8-13 \\
(11)\end{array}$ & $2-3$ & $\begin{array}{c}17-21 \\
(20)\end{array}$ & $2-6$ & $2-3$ & \multicolumn{2}{|c|}{-} & \\
\hline Females $(\mathrm{n}=5)$ & $\begin{array}{c}12-14 \\
(13)\end{array}$ & $2-4$ & $\begin{array}{c}20-24 \\
(21)\end{array}$ & $2-6$ & $2-3$ & \multicolumn{2}{|c|}{$\begin{array}{c}12.3-16.4 \\
(14.2)\end{array}$} & \\
\hline
\end{tabular}

of N. marginatus from Sumatra resembles N. vittatus, we consider the species described by Walker (1869) as a junior synonym of $N$. vittatus.

\section{Discussion}

This extensive taxonomic revision of the genus Nisitrus allowed us to assess the validity of most of the existing species, to redefine the genus and to describe five new species from Malay Peninsula and Borneo. We consider N. sumatrensis (Rehn, 1909) as a junior synonym of N. insignis Saussure, 1878; and N. marginatus (Walker, 1869) as a junior synonym of $N$. vittatus, and N. maculosus (Walker, 1871) as a dubious name (Table 2). In total, we recognise 10 valid species in the genus.

We observed that unlike typical crickets and other eneopterines recently revised taxonomically (e.g., Jaiswara et al. 2018, 2019; Robillard et al. 2014), male genitalia may not always be useful for differentiating species in Nisitrus. Male genitalia can be variable within species of Nisitrus, partly due to their more membranous nature, which can be deformed due to preservation or state of specimens (e.g., age of specimen at collection date, method of preservation and/or age of specimen). Female genitalia can be more useful than male genitalia in some instances, as for example to differentiate $N$. vittatus and $N$. malaya sp. nov. In general, species were more accurately differentiated by colour patterns, especially those on the face, pronotum lateral lobes and wings. However, colouration of the head and lateral lobe of pronotum can also be variable within species (e.g., in $N$. insignis and $N$. brunnerianus), making their use as specific characters uneasy. For example, in $N$. insignis, there are two clear variants from Sumatra and the smaller neighbouring Mentawai Islands, which made us hesitate whether there were one or two distinct species. Likewise, we observed that lateral lobe of pronotum in $N$. brunnerianus can range from completely black, with a small yellow spot, to bicolour, with ventral half yellow. Surprisingly, juveniles of Nisitrus can be distinctly different in their live colour patterns in species which have very similar adult morphology. This is particularly the case of $N$. vittatus and $N$. malaya sp. nov. However, juveniles are unknown for most species other than from anecdotal observations. Lastly, male call properties (both time and frequency domains) can also be used as evidence for species delimitation, but recordings are also rare for most species.

Although the phylogenetic tree obtained from the $12 \mathrm{~S}$ mitochondrial marker probably does not reflect robust evolutionary relationships of the species of Nisitrus, this molecular marker allowed us to test species delimitation for the well-sampled species. It strongly supported the fact that $N$. malaya sp. nov. was a distinct species from $N$. vittatus, adding to the evidence from juvenile colouration and acoustics. To reconstruct a robust phylogeny, multigene or genomic data should be used, in particular to include 
species only known by old specimens. A study on the phylogeny and evolution of Nisitrus was previously impossible because the taxonomy of this genus still warranted a revision to describe unknown species and to identify diagnostic characters to delineate species. Nonetheless, based on this first taxonomic revision of this genus, it is now possible to follow up with a new study to investigate questions on the evolution, speciation and biogeography of these crickets.

The distribution map (Fig. 5) based on this study shows that Nisitrus can be found in Malay Peninsula, Sumatra, Borneo and Java. Two species are found in Malay Peninsula, three in Sumatra and six in Borneo. We also found that in many parts of the distribution of Nisitrus, two or more species can coexist. This is the case for $N$. insignis and $N$. hughtani sp. nov. in Sumatra as well as $N$. vittatus, $N$. crucius sp. nov. and $N$. rindu sp. nov. in parts of Borneo. However, we postulate that samplings in Borneo and Java are probably insufficient and the current map does not represent the true diversity and species distribution in these islands.

Lastly, there is still very little known about the ecology of most species as most natural history notes are anecdotal. This taxonomic study allows for future investigations on ecological questions, such as what predicts the activity, abundance and diversity of Nisitrus, and what the microhabitat, habitat and dietary preferences are (Fig. 28). Given that species of this genus can be locally abundant and charismatic, Nisitrus can potentially be used as flagship and indicator species when a better understanding of their ecology and behaviour is available.

\section{Acknowledgements}

We thank Andrej Gorochov (ZIN) for providing samples from the collections of Saint Petersburg; Jérôme Constant and Carole Paleco (RBINS) for their help during the study of the collections of the Royal Belgian Institute of Natural sciences, Brussels, funded by the SYNTHESYS European program (BE-TAF-6640); Rob de Vries, Caroline Pepermans and Luc Willemse (NBC Naturalis) for their help with the Leiden collections; Sigfrid Ingrisch (ZFMK) for providing specimens from Sumatra and Borneo; Ellen Sandström Biological Museum, Lund University; Martin Husemann for the loan of material from Hamburg museum; Russell Cox and Dan Bickel for the loan of material from the Australian Museum; Judith Marshall and George Beccaloni (BMNH) for their help during the study of the Natural History Museum of London collections (funded by the SYNTHESYS European program GB-TAF-531); Peter Schwendinger and John Hollier (MHNG) for their help during the study of Genève collections; and Oscar Effendi and Erni Ernawati (MZB, Indonesia) for their help during the study of eneopterine crickets in Cibinong, Indonesia (MZB), and all the other persons helping us in the collection of crickets and in some other aspects. MKT thanks Huiqing Yeo (in Brunei Darussalam), Siew Tin Toh (in Sandakan), Momin Binti, John Lee Yukang and Saudi Bintang (in Sandakan) for field assistance. The permissions for collecting and exporting material were granted by the Forestry Department, Ministry of Primary Resources and Tourism, Brunei Darussalam and the Biodiversity Research and Innovation Centre (BioRIC) (JPH/PDK/01 Pt 2 and BioRIC/HOB/TAD/51-80 respectively); and the Sabah Biodiversity Centre (JKM/MBS.1000-2/3 JLD.3 (99)) (for Sandakan). The work of MKT was supported by the Orthoptera Species File Grant 2019 under the taxonomic research project titled "Contribution to the species diversity and acoustic data on Orthoptera from Sandakan (Borneo, East Malaysia, Sabah)"; and Percy Sladen Memorial Fund (The Linnean Society of London) under the project titled "Advancing biodiversity informatics of Orthoptera from Brunei Darussalam" and the Fyssen Foundation Postdoctoral Fellowship. The authors thank Arthur Anker, Ganjar Cahyadi, Charlie Elder, Oscar Johnson, Michael Kesl, Marcus Ng, Dries Nys and Marion Vancauwenbergh, Kaitlyn O'Brien, Marcel Silvius, and James Steamer for allowing the use of their insitu photographs; and Jeff Zhang for the recordings of Nisitrus musicus. 


\section{References}

Baroga-Barbecho J.B., Yap S.A., Tan M.K. \& Robillard T. 2019. Taxonomic review of the genus Paranisitra Chopard (Orthoptera: Gryllidae: Eneopterinae: Nisitrini) with description of a new species from Mindanao. Zootaxa 4568 (1): 81-96. https://doi.org/10.11646/zootaxa.4568.1.5

Buys D.W., Witkamp H., Endert F.H., Siebers H.C. \& Bosch D.F.K. (1927). Midden-Oost-Borneo Expeditie 1925. Kolff \& Co., Weltevreden.

Cigliano M.M., Braun H., Eades D.C. \& Otte D. 2020. Orthoptera Species File Online. Version 5 (5.0). Available from http://orthoptera.speciesfile.org/HomePage/Orthoptera/HomePage.aspx [accessed 8 Mar. 2020].

Chopard L. 1929. Spolia Mentawiensia: Gryllidae. Bulletin of the Raffles Museum 2: 98-118.

Chopard L. 1940. Results of the Oxford University expedition to Sarawak (Borneo), 1932. Gryllacridae and Gryllidae (Orthoptera). The Entomologist's Monthly Magazine 476 (8-9): 189-192; 193-204.

Chopard L. 1968. Fam. Gryllidae: Subfam. Mogoplistinae, Myrmecophilinae, Scleropterinae, Cachoplistinae, Pteroplistinae, Pentacentrinae, Phalangopsinae, Trigonidiinae, Eneopterinae; Fam. Oecanthidae, Gryllotalpidae. In: Beier M. (ed.) Orthopterorum Catalogus 12: 213-500. Junk, 's-Gravenhage [The Hague].

Chopard L. 1969. Grylloidea. In: Sewell R.B.S. (ed.) The fauna of India and the adjacent countries. Orthoptera. Vol. 2.: 1-421. Zoological Survey of India and Baptist Mission Press, Calcutta.

Desutter L. 1987. Structure et évolution du complexe phallique des Gryllidea (Orthoptera) et classification des genres néotropicaux de Grylloidea.1ère partie. Annales de la Société entomologique de France (N.S.) 23: 213-239.

Desutter-Grandcolas L. 1990. Étude phylogénétique, biogéographique et écologique des Grylloidea néotropicaux (Insectes, Orthoptères). PhD thesis, Universite de Paris-Sud, Centre d'Orsay, France.

Desutter-Grandcolas L. 2003. Phylogeny and the evolution of acoustic communication in extant Ensifera (Insecta, Orthoptera). Zoologica Scripta 32: 525-561. https://doi.org/10.1046/j.1463-6409.2003.00142.x

Desutter-Grandcolas L., Blanchet E., Robillard T., Magal C., Vannier F. \& Dangles O. 2010. Evolution of the cercal sensory system in a tropical cricket clade (Orthoptera: Grylloidea: Eneopterinae): A phylogenetic approach. Biological Journal of the Linnean Society 99: 614-631.

https://doi.org/10.1111/j.1095-8312.2009.01371.x

Dong J., Kergoat G.J., Vicente N., Rahmadi C., Xu S. \& Robillard T. 2018. Biogeographic patterns and diversification dynamics of the genus Cardiodactylus Saussure (Orthoptera, Grylloidea, Eneopterinae) in Southeast Asia. Molecular Phylogenetics and Evolution 129: 1-14.

https://doi.org/10.1016/j.ympev.2018.06.001

Gorochov A.V. 2009. A review of the genus Paranisitra Chopard (Orthoptera: Gryllidae: Eneopterinae). Proceedings of the Zoological Institute of the Russian Academy of Sciences 313 (4): 435-439.

Gorochov A.V. 2015. Evolution and taxonomic significance of the copulatory apparatus in Ensifera (Orthoptera). Part 2: Male genitalia in Grylloidea (Orthoptera: Ensifera). Zoosystematica Rossica 24 (1): 31-41. https://doi.org/10.31610/zsr/2015.24.1.31

Haan W. 1844. Bijdragen tot de kennis der Orthoptera. In: Temminck C.J. (ed.) Verhandelingen over de Natuurlijke Geschiedenis der Nederlandsche Overzeesche Bezittingen 24: 229-248. In commissie bij S. en J. Luchtmans, en C.C. van der Hoek, Leiden.

Hall T.A. 1999. BioEdit: a user-friendly biological sequence alignment editor and analysis program for Windows 95/98/NT. Nucleic Acids Symposium Series 41: 95-98. 
Hoang D.T., Chernomor O., von Haeseler A., Minh B.Q. \& Vinh L.S. 2017. UFBoot2: improving the ultrafast bootstrap approximation. Molecular Biology and Evolution 35 (2): 518-522.

https://doi.org/10.1093/molbev/msx281

Hollier J., Bruckner H. \& Heads S.W. 2013. An annotated list of the Orthoptera (Insecta) species described by Henri de Saussure, with an account of the primary type material housed in the Muséum d'histoire naturelle de Genève, Part 5: Grylloidea. Revue suisse de Zoologie 120 (3): 445-535.

iNaturalist 2020. iNaturalist. Available from https://www.inaturalist.org/ [accessed 17 Jun. 2021].

Ingrisch S. 1987. Neue Grillen von Borneo und aus Thailand (Insecta: Saltatoria: Grylloidea). Senckenbergiana biologica 68 (1-3): 163-185.

Jaiswara R., Dong J. \& Robillard T. 2018. Revision of the genus Pseudolebinthus (Orthoptera, Gryllidae, Eneopterinae) with the description of a new species from Southeast Africa. Zootaxa 4521 (2): 265-274. https://doi.org/10.11646/zootaxa.4521.2.7

Jaiswara R., Dong J., Ma L., Yin H. \& Robillard T. 2019. Taxonomic revision of the genus Xenogryllus (Orthoptera, Gryllidae, Eneopterinae). Zootaxa 4545 (3): 301-338.

https://doi.org/10.11646/zootaxa.4545.3.1

Kalyaanamoorthy S., Minh B.Q., Wong T.F.K., von Haeseler A. \& Jermiin L.S. 2017. ModelFinder: Fast model selection for accurate phylogenetic estimates. Nature Methods 14: 587-589.

https://doi.org/10.1038/nmeth.4285

Katoh K., Rozewicki J. \& Yamada K.D. 2017. MAFFT online service: multiple sequence alignment, interactive sequence choice and visualization. Briefings in Bioinformatics 20 (4): 1160-1166.

https://doi.org/10.1093/bib/bbx108

Kearse M., Moir R., Wilson A., Stones-Havas S., Cheung M., Sturrock S., Buxton S., Cooper A., Markowitz S., Duran C., Thierer T., Ashton B., Meintjes P. \& Drummond A. 2012. Geneious basic: An integrated and extendable desktop software platform for the organization and analysis of sequence data. Bioinformatics 28 (12): 1647-1649. https://doi.org/10.1093/bioinformatics/bts199

Kirby W.F. 1906. A Synonymic Catalogue of Orthoptera. Vol. 2. Orthoptera Saltatoria. Part I. (Achetidae et Phasgonuridae). Trustees of the british Museum, London.

Kuraku S., Zmasek C.M., Nishimura O. \& Katoh K. 2013. aLeaves facilitates on-demand exploration of metazoan gene family trees on MAFFT sequence alignment server with enhanced interactivity. Nucleic Acids Research 41: 22-28. https://doi.org/10.1093/nar/gkt389

Nattier R., Robillard T., Desutter-Grandcolas L., Couloux A. \& Grandcolas P. 2011. Older than New Caledonia emergence? A molecular phylogenetic study of the eneopterine crickets (Orthoptera: Grylloidea). Journal of Biogeography 38 (11): 2195-2209. https://doi.org/10.1111/j.1365-2699.2011.02563.x

Nguyen L.T., Schmidt H.A., von Haeseler A. \& Minh B.Q. 2015. IQ-TREE: a fast and effective stochastic algorithm for estimating maximum-likelihood phylogenies. Molecular Biology and Evolution 32 (1): 268-274. https://doi.org/10.1093/molbev/msu300

Otte D. 1994. Orthoptera Species File. Vol. 1. Crickets (Grylloidea). Orthopterists' Society and the ANSP, Philadelphia.

Preston-Mafham K. 2000. Diurnal mating behaviour of a Nisitrus sp. cricket (Orthoptera: Gryllidae) from Sumatra. Journal of Natural History 34 (12): 2241-2250. https://doi.org/10.1080/002229300750037884

R Core Team. 2018. R: A language and environment for statistical computing. R Foundation for Statistical Computing, Vienna, Austria. Available from https://www.R-project.org/ [accessed 17 Jun. 2021]. 
TAN M.K. et al., Revision of Nisitrus (Orthoptera: Eneopterinae)

Ragge D.R. \& Reynolds W.J. 1998. The Songs of the Grasshoppers and Crickets of Western Europe. Harley Books, Colchester, England.

Rehn J.A.G. 1909. A contribution to the knowledge of the Orthoptera of Sumatra. Bulletin of the American Museum of Natural History 26: 177-211.

Robillard R. \& Desutter-Grandcolas L. 2004a. Evolution of acoustic communication in crickets: phylogeny of Eneopterinae reveals an adaptive radiation involving high-frequency calling (Orthoptera, Grylloidea, Eneopteridae). Anais da Academia Brasileira de Ciências 76 (2): 297-300.

https://doi.org/10.1590/S0001-37652004000200018

Robillard R. \& Desutter-Grandcolas L. 2004b. High-frequency calling in Eneopterinae crickets (Orthoptera, Grylloidea, Eneopteridae): adaptive radiation revealed by phylogenetic analysis. Biological Journal of the Linnean Society 83 (4): 577-584. https://doi.org/10.1111/j.1095-8312.2004.00417.x

Robillard R. \& Desutter-Grandcolas L. 2004c. Phylogeny and the modalities of acoustic diversification in extant Eneopterinae (Insecta, Orthoptera, Grylloidea, Eneopteridae). Cladistics 20 (3): 271-293. https://doi.org/10.1111/j.1096-0031.2004.00025.x

Robillard T. \& Desutter-Grandcolas L. 2006. Phylogeny of the cricket subfamily Eneopterinae (Orthoptera, Grylloidea, Eneopteridae) based on four molecular loci and morphology. Molecular Phylogenetics and Evolution 40: 643-661. https://doi.org/10.1016/j.ympev.2005.10.019

Robillard R. \& Desutter-Grandcolas L. 2008. Clarification of the taxonomy of extant crickets of the subfamily Eneopterinae (Orthoptera: Grylloidea; Gryllidae). Zootaxa 1789: 66-68. https://doi.org/10.11646/zootaxa.1789.1.3

Robillard R. \& Desutter-Grandcolas L. 2011. The complex stridulatory behavior of the cricket Eneoptera guyanensis Chopard (Orthoptera: Grylloidea: Eneopterinae). Journal of Insect Physiology 57 (6): 694703. https://doi.org/10.1016/j.jinsphys.2011.02.005

Robillard T. \& Tan M.K. 2013. A taxonomic review of common but little known crickets from Singapore and the Philippines (Insecta: Orthoptera: Eneopterinae). Raffles Bulletin of Zoology 61 (2): 705-725.

Robillard R., Grandcolas P. \& Desutter-Grandcolas L. 2007. A shift toward harmonics for high-frequency calling shown with phylogenetic study of frequency spectra in Eneopterinae crickets (Orthoptera, Grylloidea, Eneopteridae). Canadian Journal of Zoology 85 (12): 1264-1275. https://doi.org/10.1139/Z07-106

Robillard T., Montealegre-Z. F., Desutter-Grandcolas L., Grandcolas P. \& Robert D. 2013. Mechanisms of high-frequency song generation in brachypterous crickets and the role of ghost frequencies. Journal of Experimental Biology 216 (11): 2001-2011. https://doi.org/10.1242/jeb.083964

Robillard T., Gorochov A.V., Poulain S. \& Suhardjono Y.R. 2014. Revision of the cricket genus Cardiodactylus (Orthoptera, Eneopterinae, Lebinthini): the species from both sides of the Wallace line, with description of 25 new species. Zootaxa 3854 (1): 1-104. https://doi.org/10.11646/zootaxa.3854.1.1

Saussure H. 1878. Mélanges orthoptérologiques. VI. Fascicule Gryllides. Mémoires de la Société de Physique et d'Histoire naturelle de Genève 25 (2): 369-704 [505-834].

Schneider E.S., Römer H., Robillard T. \& Schmidt A.K.D. 2017. Hearing with exceptionally thin tympana: Ear morphology and tympanal membrane vibrations in eneopterine crickets. Scientific Reports 7 (15266): 1-12. https://doi.org/10.1038/s41598-017-15282-z

Sueur J., Aubin T. \& Simonis C. 2008. Seewave, a free modular tool for sound analysis and synthesis. Bioacoustics 18 (2): 213-226. https://doi.org/10.1080/09524622.2008.9753600

Tan M.K. 2012. Orthoptera in the Bukit Timah and Central Catchment Nature Reserves (Part 2): Suborder Ensifera. Raffles Museum of Biodiversity Research, National University Singapore, Singapore. Available 
from https://1kcnhm.nus.edu.sg/wp-content/uploads/sites/10/app/uploads/2017/04/ensifera_btnr_ccnr.pdf [accessed 16 Jun. 2021].

Tan M.K. 2017. Orthoptera in the Bukit Timah and Central Catchment Nature Reserves (Part 2): Suborder Ensifera. 2nd Edition. Lee Kong Chian Natural History Museum, National University of Singapore, Singapore. Available from

https://1kcnhm.nus.edu.sg/wp-content/uploads/sites/10/app/uploads/2017/09/orthoptera_part2.pdf [accessed 16 Jun. 2021].

Tan M.K. \& Robillard T. 2014. A new species of Cardiodactylus (Orthoptera: Grylloidea: Eneopterinae) from Singapore. Zootaxa 3764 (3): 364-376. https://doi.org/10.11646/zootaxa.3764.3.6

Tan M.K. \& Wahab R.A. 2018. Preliminary study on the diversity of Orthoptera from Kuala Belalong Field Studies Centre, Brunei Darussalam, Borneo. Journal of Orthoptera Research 27 (2): 119-142.

https://doi.org/10.3897/jor.27.24152

Tan M.K., Ngiam R.W.J. \& Ismail M.R.B. 2012. A checklist of Orthoptera in Singapore parks. Nature in Singapore 5: 61-67.

Tan M.K. Ngiam R.W.J., Ismail M.R.B. \& Ibrahim H. 2013a. Diversity of Orthoptera from Neo Tiew Lane Two, Singapore. Nature in Singapore 6: 211-222.

Tan M.K., Yeo H., Hasnan S., Woon S.Z.S. \& Wu B. 2013b. A rapid comparison of the Orthoptera communities between Bukit Brown Cemetery and Lornie Trail of Central Catchment Nature Reserve, Singapore. Nature in Singapore 6: 97-103.

Tan M.K., Yeo H. \& Lee J.X.Q. 2015. Diversity of entomofauna (Orthoptera, Reduviidae and Aculeata) in the Mandai-Lake Road area, Singapore. Nature in Singapore 8: 37-51.

Tan M.K., Artchawakom T., Wahab R.A., Lee C.-Y., Belabut D.M. \& Tan H.T.W. 2017. Overlooked flower visiting Orthoptera in Southeast Asia. Journal of Orthoptera Research 26 (2): 143-153. https://doi.org/10.3897/jor.26.15021

Tan M.K., Japir R. \& Chung A.Y.C. 2019. Uncovering the Grylloidea and Tettigonioidea (Orthoptera: Ensifera) in the Forest Research Centre (Sepilok) Entomological Collection. Zootaxa 4701 (4): 301349. https://doi.org/10.11646/zootaxa.4701.4.1

ter Hofstede H., Schöneich S., Robillard T. \& Hedwig B. 2015. Evolution of a communication system by sensory exploitation of startle behavior. Current Biology 25: 3245-3252.

https://doi.org/10.1016/j.cub.2015.10.064

Trifinopoulos J., Nguyen L.-T., von Haeseler A. \& Minh B.Q. 2016. W-IQ-TREE: a fast online phylogenetic tool for maximum likelihood analysis. Nuclei Acids Research 44: 232-235.

https://doi.org/10.1093/nar/gkw256

Vicente N., Kergoat G.J., Dong J., Yotoko K., Legendre F., Nattier R. \& Robillard T. 2017. In and out of the Neotropics: historical biogeography of Eneopterinae crickets. Journal of Biogeography 44: 2199-2210. https://doi.org/10.1111/jbi.13026

Walker F. 1869. Catalogue of the Specimens of Dermaptera Saltatoria in the Collection of the British Museum Part 2. Trustees of the British Museum, London.

Walker F. 1871. Catalogue of the Specimens of Dermaptera Saltatoria in the Collection of the British Museum Part 5. Trustees of the British Museum, London.

Willemse L.P.M. 2001. Fauna Malesiana: Guide to the Pest Orthoptera of the Indo-Malayan Region. Backhuys Publishers, Leiden. 
Manuscript received: 19 January 2021

Manuscript accepted: 13 April 2021

Published on: 28 July 2021

Topic editor: Nesrine Akkari

Desk editor: Radka Rosenbaumová

Printed versions of all papers are also deposited in the libraries of the institutes that are members of the EJT consortium: Muséum national d'histoire naturelle, Paris, France; Meise Botanic Garden, Belgium; Royal Museum for Central Africa, Tervuren, Belgium; Royal Belgian Institute of Natural Sciences, Brussels, Belgium; Natural History Museum of Denmark, Copenhagen, Denmark; Naturalis Biodiversity Center, Leiden, the Netherlands; Museo Nacional de Ciencias Naturales-CSIC, Madrid, Spain; Real Jardín Botánico de Madrid CSIC, Spain; Zoological Research Museum Alexander Koenig, Bonn, Germany; National Museum, Prague, Czech Republic.

\section{Supplementary file}

Supp. file 1: Map from Buys et al. (1927) used for georeferencing of specimens collected during the Midden Oost Borneo Expeditie 1925 in Kalimantan.

https://doi.org/10.5852/ejt.2021.761.1449.4767 